

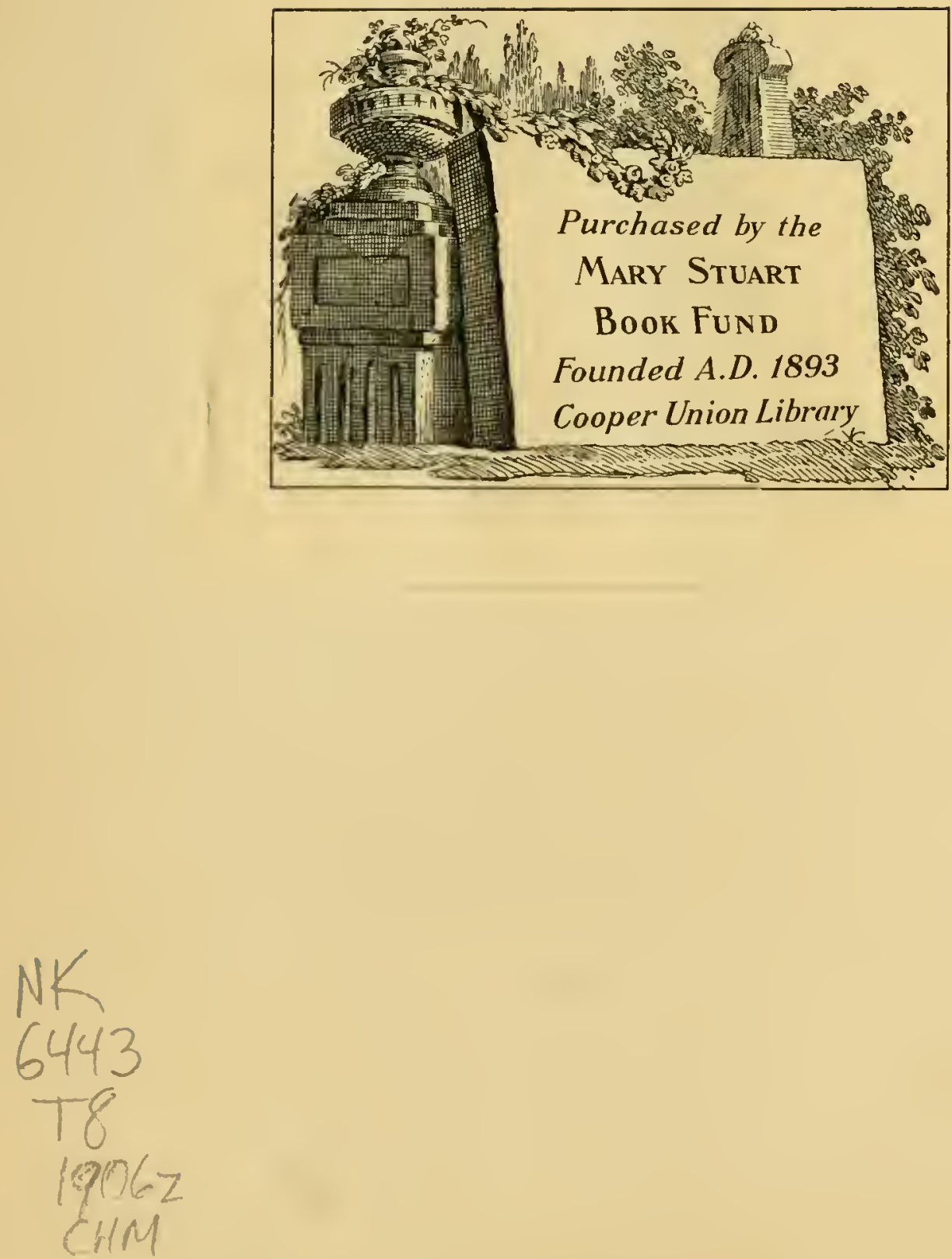


ENGLISH METAL WORK 



\title{
ENGLISH METAL WORK
}

\section{NINETY-THREE DRAWINGS}

\author{
BY WILLIAM TWOPENY \\ (1797-I 873) \\ WITH A PREFACE BY \\ LA U R E N C E B I N Y O N
}

NEW YORK: JOHN LANE COMPANY

LONDON: ARCHIBALD CONSTABLE \& CO.

M C M V I 


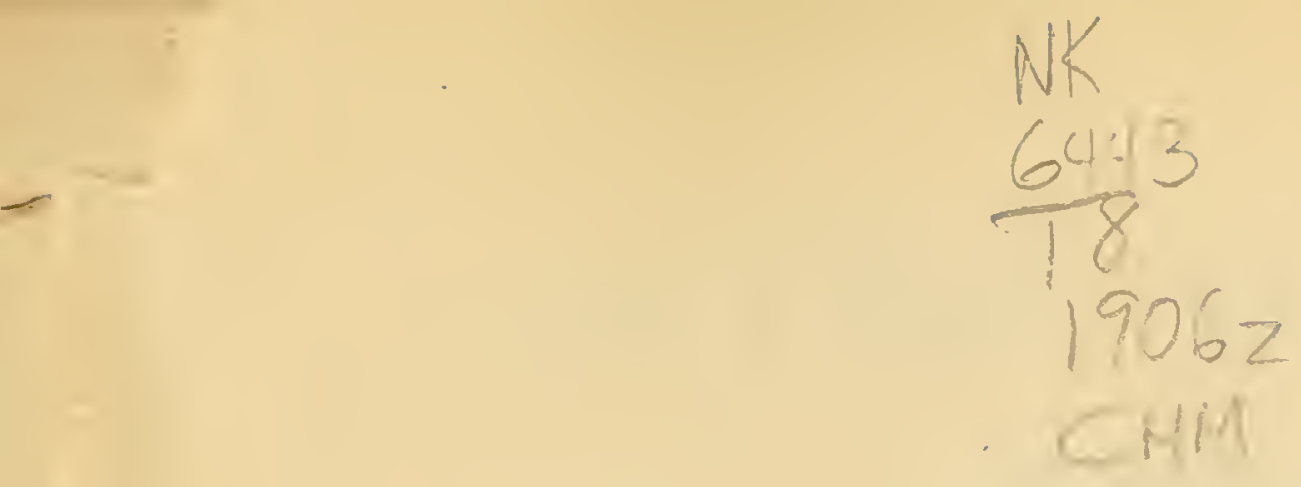<smiles>CC1(C)CC1</smiles> 


\section{Drawings of English Metal Work}

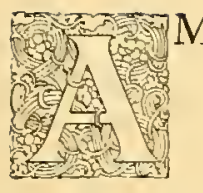

MONG the many little-known collections in the British Museum is a very large series of drawings, bound in thirteen folios, and a number of smaller volumes, by William Twopeny, presented by his brother and executor in 1874 . They are all drawings of architecture, furniture, woodwork and ironwork, made from buildings in various parts of England during the first half of the last century. They were made from the point of view of an enthusiastic antiquary, with knowledge and discrimination. Their value as a record is therefore great, and it is increased by the fact that much which is recorded by them has since disappeared. But their value as drawings is also considerable. The entire self-effacement of the draughtsman, merely bent on recording with loving precision the beauty made by English builders and craftsmen in the past, is in itself so artistic a quality that these unpretentious studies give one far more pleasure than those of similar subjects by much more famous hands.

Drawings of this class are liable to two dangers. When made by architects they are always apt to be bald and cold and tame; when made by painters, they incline to sacrifice overmuch to the picturesque. I am not now speaking of the work of such artists as Piranesi and Méryon, where architecture has been made the material of splendid imaginative design. I mean rather the work, produced so copiously in England towards the end of the eighteenth century and in the beginning of the nineteenth, the professed end of which was a record of the building drawn. Every one knows how this patient draughtsman's work was transformed by Girtin and Turner, in whom the designer's instinct soon overcame the methods of the mere delineator. From that time the drawing of architecture branched off into two lines: that so profusely illustrated by the picturesque pencil of men like Prout and Nash, and that continued to our day by professional architects. Only one or two men, hampered by no public, because working for their own pleasure, produced drawings neither bald nor picturesque, nor disabled by the effort at a compromise between two ends. Such were the studies of Ruskin. And Ruskin's best hardly excelled the pencil workmanship of 


\section{ENGLISH METAL WORK}

Twopeny. These drawings must have been unknown to Ruskin, or we should assuredly have had from him an enthusiastic page on qualities which he prized so much. Twopeny's drawing is patient almost beyond belief to our hurried age; but his patience is never suffering or fatigued; he pencils the last corners of miraculous detail with the same fervent delicacy with which he began. Without hint of trickery, without summary of formula, he makes every space interesting by sheer sensitiveness of eye and hand. We feel the various textures of stone and wood and metal, as if our fingers were passing over the surface.

And we may note that instead of deadening by continued labour, our draughtsman grew in subtlety and skill. The earlier studies have traces of the drawing-master's conventions; the later ones come ever closer to the subject in hand, with increasing intimacy and mastery of representation.

As Twopeny's aim was but the modest one of representing the buildings and architectural features which he loved, and communicating that love through his work, he is best seen perhaps in the studies of detail, where there is no thought of pictorial design. I have often wished that some of these studies might be reproduced, both to make his work known and on account of the intrinsic interest of his subject. A Japanese friend once expressed to me his wonder at the ordinary domestic architecture of modern England. "When you have such fine models of your own," he said, "why build like that?" Well, the commercial builder is probably past praying for or persuading; but no one can deny the great improvement made of recent years. And if we do not go on improving, it will not be for want of interest and aspiration. Thanks to Ruskin and Morris, belief in the unity of art has laid strong hold on Englishmen; and though some of us may deplore the actual results of the movement which has inspired the revival of the handicrafts, the movement is itself a good one. The obvious faults which make so much of this modern work restless and uncomfortable to the eye are chiefly coarseness and impatience, an itch for originality usurping the modest devotion of fine workmanship. In wrought iron work especially the want of fineness is apparent, for wrought iron demands fine workmanship. Much must be put down to lack of models, where tradition has died out. For, alas! the fine shapes that marked our old handicrafts have long ago disappeared; the domestic utensils and furniture that gave dignity, by their fine simplicity of form and careful workmanship, to country cottages, have been driven out by dull products of cheapening commerce, things whose making gave no pleasure to those who made them, and whose use gives none to those who use them. Admirable specimens of our old crafts exist, but scattered about, and in remote places for the most part. It is to these models that those who are now trying to reawaken beauty in the homely arts should turn for guidance. 


\section{ENGLISH METAL WORK}

We need not reproduce old forms with servility, but if we wish to preserve an English character we shall look long and carefully at those works which bring down to us the tradition of those who wrought so well for our ancestors.

Museums are always growing, but one cannot annex a public museum to a private workshop. The actual worker wants to live with what he admires and seeks to imitate the spirit of. Photographs are useful, and the National Pbotograpbic Record is rendering excellent and timely service. But photographs have their disadvantage ; in the case of metal work on buildings they do not isolate the object sufficiently, and they introduce into details a disturbing light and shade. For the craftsman's use a precise and sensitive drawing is much more to the purpose.

It is unfortunate that our artist should have chosen to work on paper of a decidedly yellow tone, which has made the task of the photographer a difficult one. The beauty and delicacy of the original pencil-work must not be judged by reproductions which are of necessity imperfect.

In the present volume the publishers have chosen the most representative of Twopeny's studies of metal work, believing that these will be of service to those who are occupied with the crafts of that material. A further volume may follow, containing selected studies of woodwork.

Of William Twopeny, F.S.A., the author of these drawings, there is little enough to be recorded. He had an intense love of architecture and a great fondness for antiquities; he collected books, china, pictures and other works of art, and these hobbies were the main interest of his life. The second son of Edward Soan Twopeny, ${ }^{1}$ of Rochester, and brother of Edward Twopeny, of Woodstock, Sittingbourne, he died unmarried December 5, I 873 , aged seventy-six, and was buried at St. Margaret's, Rochester. $\mathrm{He}$ was a conveyancer and a member of the Temple, and lived at 48, Upper Grosvenor Street, where he made his collections, since dispersed. Twopeny published in 1859 "Specimens of Ancient Woodwork" etched from drawings, now in the Museum collection, by W. H. Wilkinson. These etchings were carefully made, but are quite inferior to the original pencil work. He had before this published a few plates of "Capitals and other details of Ancient Architecture." There is also a lithograph, a single sheet, signed W.T. 1835 , entitled "A Stack of Ancient Chimnies and a Stack of Modern Chimnies, respectfully offered to the notice of the British Architects of the $\mathrm{r} \mathrm{g}^{\text {th }}$ century by an Amateur." The contrast thus quietly drawn between the orderly beauty and grace of the old and the freakishness and ugliness of the new, is singularly telling. What would the feelings of its author be to-day !

\section{LAURENCE BINYON.}

For the following notes on the subjects of the plates I am indebted to the kindness and special knowledge of my friend, Mr. Lawrence Weaver, F.S.A.

${ }^{1}$ I am indebted for these facts to Mr. C. D. Twopeny. 


\section{English Metal Work}

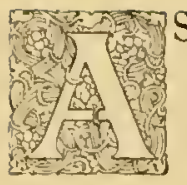

this volume is intended for craftsmen's use rather than for antiquarian study, no attempt has been made to date the various examples. With metal work it is indeed impossible to fix a date without knowledge derived from other work on the building where it is found. In many buildings, distinctly Renaissance in style, metalwork occurs which is either entirely Gothic in feeling and detail, or entirely Gothic in feeling with accidental addition of Renaissance detail. For instance, at Haddon Hall are lead rain-water pipe-heads with a classical cornice, but with large circular panels of Gothic tracery, inspired by an earlier pipehead on the same building. On the whole question of date, it may suffice to say here that until the advent in the latter part of the seventeenth century of Jean Tijou, who was employed by Wren at St. Paul's and at Hampton Court, and who published an important book of designs, I693, no foreign influence affected English ironwork : it followed the mediaeval tradition and retained the mediaeval detail.

None of the following examples is really marked by foreign influence, though some of the later door-handles, while remaining Gothic in feeling, show in their lines the free character of the Renaissance.

Where possible, dimensions have been noted. It is greatly to be regretted that Twopeny, in common with other draughtsmen, so often omitted to record these on his drawings.

L. W. 


\section{List of Plates}

\section{LEAD WORK \\ I. Rainwater Pipe-Heads, Clajerton, Somersetshire.}

The general design of these heads has been somewhat sacrificed to the desire to make the coat of arms show prominently; the heads being high up on the church tower.

\section{Rainwater Pipe-Head, Dome Alley, Winchester.}

The head, as now existing, has lost the two terminals at the top and the two curls at the bottom. The position of the vine-pattern gutter (shown in the next drawing) behind the front of the head is most unusual and pleasing in effect. A similar vine gutter occurs on Old Palace Yard, Coventry, but fixed as a parapet gutter and with a battlemented cresting.

III. Gutter and Flashing, Dome Alley, Winchester.

The gutter is cast, rounded on one side of its section and square on the other; the triangular lead flashing closes a valley between two gables.

IV. Rainwater Pipe-Head, Sherborne, Dorset.

The cable-moulding on this head is the most usual ornament for cast lead and cast ironwork; its use was an obvious thought, as a length of rope served for the actual pattern. But the chief interest here is the surface decoration in bright tin, a method used with happy effect on heads at Knole, Sevenoaks, and at Abbot's Hospital, Guildford, though in the latter case repeated coats of paint have obscured the tinning almost entirely.

V. Rainwater Pipe-Head, Stanwick, Yorkshire.

The pattern of the cresting of this head is not uncommon in early seventeenth century work, but the scale is much larger than usual. A like treatment is found on heads at Poundisford Park, Taunton, and at East Quantocks Head.

VI. Gargoyle with Wrought-Iron Bracket, Uffington Church, LinCOLNSHIRE.

The treatment is most appropriate to the material. Contrast the "grotesque beast" form of lead gargoyle illustrated by Viollet-le-Duc (Dictionnaire de l'Arcbitecture Française, s.v. "Gargouille," fig. 11), 


\section{LIST OF PLATES}

inaptly copied in metal from the usual stone gargoyle. Another simple and felicitous treatment is seen in a lead gargoyle at Hardwick Hall, formed of round pipe, slit, bulged, and twisted to the pattern of an Elizabethan puffed sleeve.

VII. Open Lead-Work, Staircase Window, Oxburgh Hall, Norfolk.

The heaviness of this lead grille is most unusual. The intersections of the tracery are ingeniously contrived.

VIII. Open Lead-Work (Ventilating Quarry), Hampton Court Palace.

A ventilating quarry of a comparatively usual type, which occurs at Haddon Hall and elsewhere. This window treatment seems to have been contemporary with the use of glass quarries, as fragments of such leadwork have been found at Fountains Abbey. It is a way of providing an air inlet which might well be revived; the shape gives every opportunity for invention in arrangement of lines.

\section{CAST-IRON WORK}

IX. Fire-Dog, Nettlecombe Court, Somersetshire.

X. Fire-Dog, Сobham Hall, Kent.

XI. Fire-Dog, Godinton, Kent.

These are almost certainly from the same foundries of the SussexWeald which produced the fire-backs, so marked a feature of English iron-work. The patterns for the ornaments in the face of the pillars were obviously loose patterns, as the sacred monogram and other devices were indiscriminately used on the same main pattern.

XiI. Fire-Dog, Gilston Park, Hertfordshire.

XIII. Fire-Dog, Leeds Castle, Kent

\section{IVROUGHT-IRON WORK}

XIV. Railing Standard, Sir Hugh Smithson's Tomb, Stanwick, Yorkshire.

XV. Railing Standards, Eyworth Churcit, Bedfordshire.

XVI. Railing Standards, Salisbury, Sherborne, and Clefve (Somerset).

XVII. Railing Standards, I psden and Warborough, Oxfordshire.

XVIII. Grille of Dairy Window, Ulcombe, Kent.

Note the forged straps that link the scroll work: how far superior to the spherical nuts and bolts of most modern ironwork, which give so unpleasantly spotty an appearance.

XIX. Vane, Oxburgh Hali, Norfolk.

A peculiarly rich example of the varied use of practically a single form, the fleur de lys.

XX. Vane, Worthorpe, Northamptonshire. 


\section{LIST OF PLATES}

XXi. Reading Desk, Almitick Church.

Here a charming unity of effect is given by the use of a simple form, the piercing of the sheet iron desk being a simple arrangement of intersecting circles. Essays in the direction of similar wrought-iron lecterns, combined with leather work, would be a happy change from the usual brazen bird from Birmingham.

XXII. Hourglass Bracket, South Stoke Church, Oxfordshire.

The absence of the forged straps referred to in No. xviii. has a feeble effect; it looks as if the scrolls had been glued on.

XXili. Hinge-Straps on West Door, Leighton Buzzard Church, BedfordSHIRE.

XXIV. Hinge-Strap on South Door of Church, Hough on the Hill, LinCOLNSHIRE.

XXV. Hinge-Strap, Chacombe Church, Northamptonshire.

XXVI. Hinge-Strap, Sowerby Church, Yorkshire.

XXVII. Hinge, Glasses, Somerset.

XXVIII. Door-Strap, Sowerby Church, Yorkshire.

XXIX. Hinge, Boughton Malherbe, Kent.

Familiar Cock pattern.

XXX. Knocker, Stockbury Vicarage, Kent.

XXXI. Knocker and Rose of Hande

XXXII. Knocker, Kirkbridge, Stanwick, Yorkshire.

Obviously the staple which now attaches the knocker to the door is a recent makeshift; the original back plate with two eyes, in which worked the two ends of the crosspiece, has disappeared.

XXXiII. Handie for Latch, Athelstane Abbey, Yorkshire.

Hardly a pattern for imitation, the slightness of the grip not being very grateful to the hand. This type, without back plate, is often called a Suffolk latch.

XXXIV. Norfolk Latch, Wokey, Somerset.

XXXV. Iron Box in the Possession of the Hon. Elizabeth Cust.

The treatment is so rich as almost to suggest French or Flemish work.

XXXVI. Lock and Hasp of Iron Box.

XXXVit. Chest With Iron Fittings, Northfleet Church, Kent.

Probably for vestments. Note the eminently practical arrangement of the handles. When raised, the loose rings stand above the top of the box. 


\section{LIST OF PLATES}

\section{XXXVili. Lock on a Chest, Nettlecombe Court, Somerset.}

The shell pattern ears are most unusual; the elaboration of the case is needlessly architectural.

XXXIX. Lock, Eastbury House, Barking, Essex.

The hatchet shape of the case is characteristic of the early sixteenth century. There are several similar locks at Canterbury Cathedral. In this lock the keyhole is not covered, but frequently one of the bars is pivoted at the top end and covers the hole.

XL. Lock, Nettlecombe Court, Somerset.

Probably late sixteenth century. The incised ornament is very attractive and not obtrusive, like the elaborately overdone locks of the late seventeenth century.

XLI. Lock, Hencrave Hald, Suffolk.

Early Renaissance treatment. Note the suggestion of birds.

XliI. Padlock, Thirsk $\mathrm{Church}_{\text {, Yorkshire. }}$

Xliti. Key in the Possession of Mr. Douce.

Xliv. Key in the Possession of Archdeacon Singleton.

XLV. Key at Nettlecombe Court, Somerset.

Xlvi. Copper Key found at Camer, Meopham, Kent.

Probably very early and, on account of the material, of great archaeological interest.

XlViI. Door-Handle, Woodland, Mere, Wiltshire.

XlviII. Rose for Door-Hande, Bremhill Church, Wiltshire.

The handle itself has disappeared, but was doubtless a simple twisted ring. The curls on the socket of the ring are unusual, and amusing.

XliX. Two Door-Handles, Snodland Church, Kent.

L. Door-Handle, Bromham Church, Wiltshire.

The stiff architectural treatment of the back plate is overcome by the very easy lines of the ring and the engraving of cabled lines across the flat of the ring.

Li. Door-Hande, Wickham Court, Kent.

Length, $7 \frac{\pi}{2}$ in. The engraved radiating lines give by simple means a delicacy and interest to the large flat surface of the rose.

LiI. Door-Hande, Ryarsh Church, Kent.

Diameter, 5 in. The combination of beating up dots from the back of the rose, of piercing it, of the punch marks on the handle and the due disregard of regularity in the twisting, makes a most interesting fitting. 


\section{LIST OF PLATES}

LiII. Door-Hande, Ightham Mote, Kent.

The vigour of the hexagonal section of the ring working into the bold round swellings at the side seems to call for a bolder treatment of the rose than the rather too delicate piercing of a thin plate.

LiV. Door-Handle, Glasses, Cleeve, Somerset.

Diameter, 6 in. The simple but effective piercing of the rose is a not uncommon treatment. Twopeny elsewhere draws an almost identical handle.

LV. Door-Handle, Street, Somersetshire.

Length, 6 in.

LVI. Door-Hande, Westwell Church, Kent.

Note the pleasant effect of the large proportion of rose to handle.

LVII. Door-Handle, Kirkbridge, Stanwick, Yorkshire.

Length, $4 \frac{3}{4}$ in. Note the excellent grip afforded by the rings at the bottom of the handle.

LVIII. Door-Handle, Layer Marney Hall, Essex.

Note the suave lines of the rose.

LIX. Door-Handle, Brown's Hospital, Stamford.

LX. Door-Handle, Claverton, Somerset.

LXI. Door-Handle, Norrington House, Wilts.

LXII. Door-Handle, Lyneham, Wilts.

The lines of the back plate are feeble.

LXIII. Door-Handle, and Key-Escutcheon, Claverton, Somerset.

The rose of the handle seems too refined.

LXIV. Door-Handle, Kirkbridge, Stanwick, Yorkshire.

Length, $5 \frac{1}{4}$ in.

LXV. Door-Handle and Key-Escutcheon, Glasses, Somerset.

Handle, 4 in. long. Escutcheon, 2 in. long.

LXVI. Handle-Rose, St. Sepulchre's, Northampton; Key-Escutcheon, Thurnham $\mathrm{C}_{\text {hurch, }} \mathrm{K}$ ent.

These well compare the restraint of Gothic treatment (the handlerose) with the greater liberty of line in the later escutcheon.

LXVII. Knocker, Bexon, Bredgar, Kent.

LXVIII. Knocker, Strood, Kent.

Fixed on the stile of a six-panelled door.

LXIX. KNocker, Rochester.

Fixed on one of the twenty panels of a door. 


\section{LIST OF PLATES}

LXX. Door-Hande, Ryhall Church, Rutland.

The ogee curves of the rose seem rather coarse against the slim handle.

LXXI. Door-Handle, Egerton Church, Kent.

Note the original outline of the rose.

LXXII. Door-Handle, Corsham, Wilts.

The rose shows a great freedom of line.

LXXIII. Door-Handle, Coulstead, Stockbury, Kent.

Length, $4 \frac{\pi}{4}$ in. Edge of rose is chamfered.

LXXIV. Hande-Rose, Town Hall, Colchester.

A notable example of the almost painful elaboration of Gothic detail in a confined space.

LXXV. Handle-Rose, Brown Street, Salisbury.

The raised and moulded edge gives great delicacy of light and shadow.

LXXVi. Handle-Rose, Gilden Morden Church, Cambridgeshire.

This and the next drawing show the happy effects of simple forms with workmanship of the slightest.

LXXVII. Handle-Rose, Carlby Church, Lincolnshire.

LXXVIII. Hande-Rose, Beauchamp Chapel, Warwick.

This and the two following show the sunk tracery treatment of flat metal at its best. Of the three, lxxx. gives the richest effect with the least amount of workmanship.

LXXiX. Handle-Rose, Beauchamp Chapel, Warwick.

LXXX. Handle-Rose, Beauchamp Chapel, Warivick.

LXXXI. Key-Escutcheon, Wickham Court, Kent.

Length, $5 \frac{\frac{\pi}{2}}{\mathrm{in}}$, width, $5 \frac{\mathrm{T}}{2}$ in. A rather puzzling fitting. It is still in its place as a key escutcheon, but the use of the hinge, at the bottom of which the fixed butt alone remains, is not clear. Presumably therc was a hinged cover, but it is most unusual for it to hinge from the bottom.

LXXXII. Key-Escutcheon, Westbourne Church, Sussex.

LXXXiII. Key-Escutcheon, Harlaxton Manor House, Lincolnshire.

Length, 5 in.

LXXXIV. Key-Escutcheon, Coulstead, Stockbury, Kent.

4 in. long, $3 \frac{\pi}{2}$ in. wide. Edge chamfered.

LXXXV. Key-Escutcheon, Hythe Church, Kent.

Note the pleasant effect of the thickened end.

LXXXVI. Key-Escutcheon, Boughton Malherbe, Kent.

A very jaunty outline. 


\section{LIST OF PLATES}

LXXXVII. Key-Escutcheon, Uffington Church, Lincolnshire.

LXXXViII. Handee-Plate, Eastbury House, Essex.

Doubtless the plate of a loose bar handle as xc., an example of the increasing complication of line shown in the later work, and of the desire to get richness of effect by meaningless curves rather than by the greater labour of variation in surface, shown for example in the Gothic treatment of lxxviii. to lxxx.

LXXXIX. Fixed Bar-Handle, Betchfield, Northumberland.

About 10 in. long. Note the flattening and return of the two ends of the bar to meet at middle of back plate, and compare the easy lines of the bar with the restless edge of the plate.

XC. Loose Bar-Handle, Witton Tower, Northumberiand.

Altogether a rather clumsy design.

XCI. Swinging Bar-Hande, Hamipton Court.

$6 \frac{\pi}{4}$ in. long.

XCiI. Swinging Bar-Handle, Sedgebrook Church, Lincolnshire.

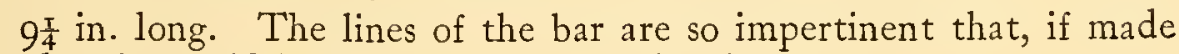
to-day, it would be scorned as "New Art."

XCIII. Window-Latch, Ipsden Vicarage, Oxfordshire.

A very efficient fastening for iron casements. The type is not uncommon; there are others on the same lines at Haddon Hall and Guildford. 


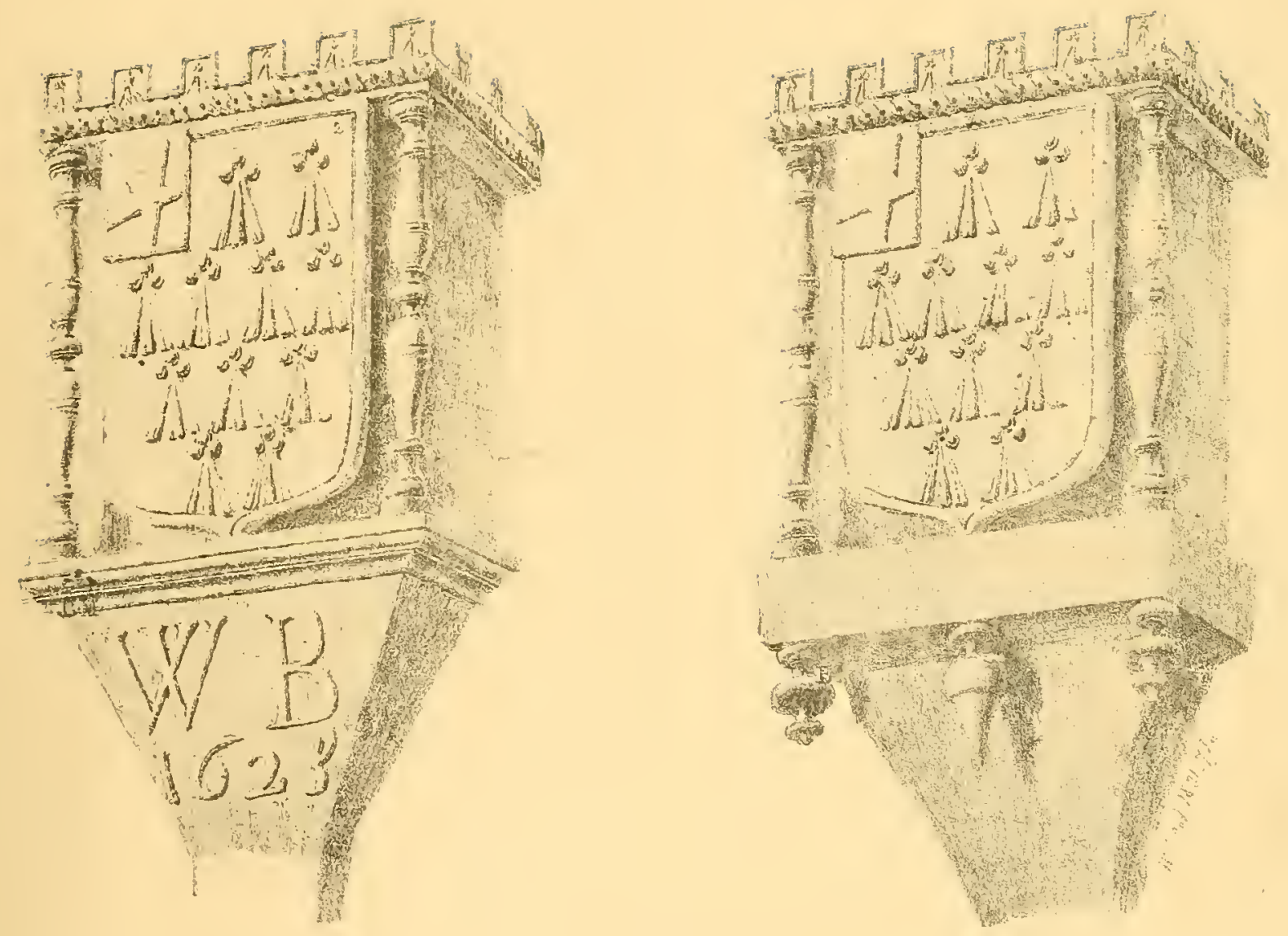

I RAINWATER PIPE-HEADS, CLAVERTON, SOMERSETSHIRE. 



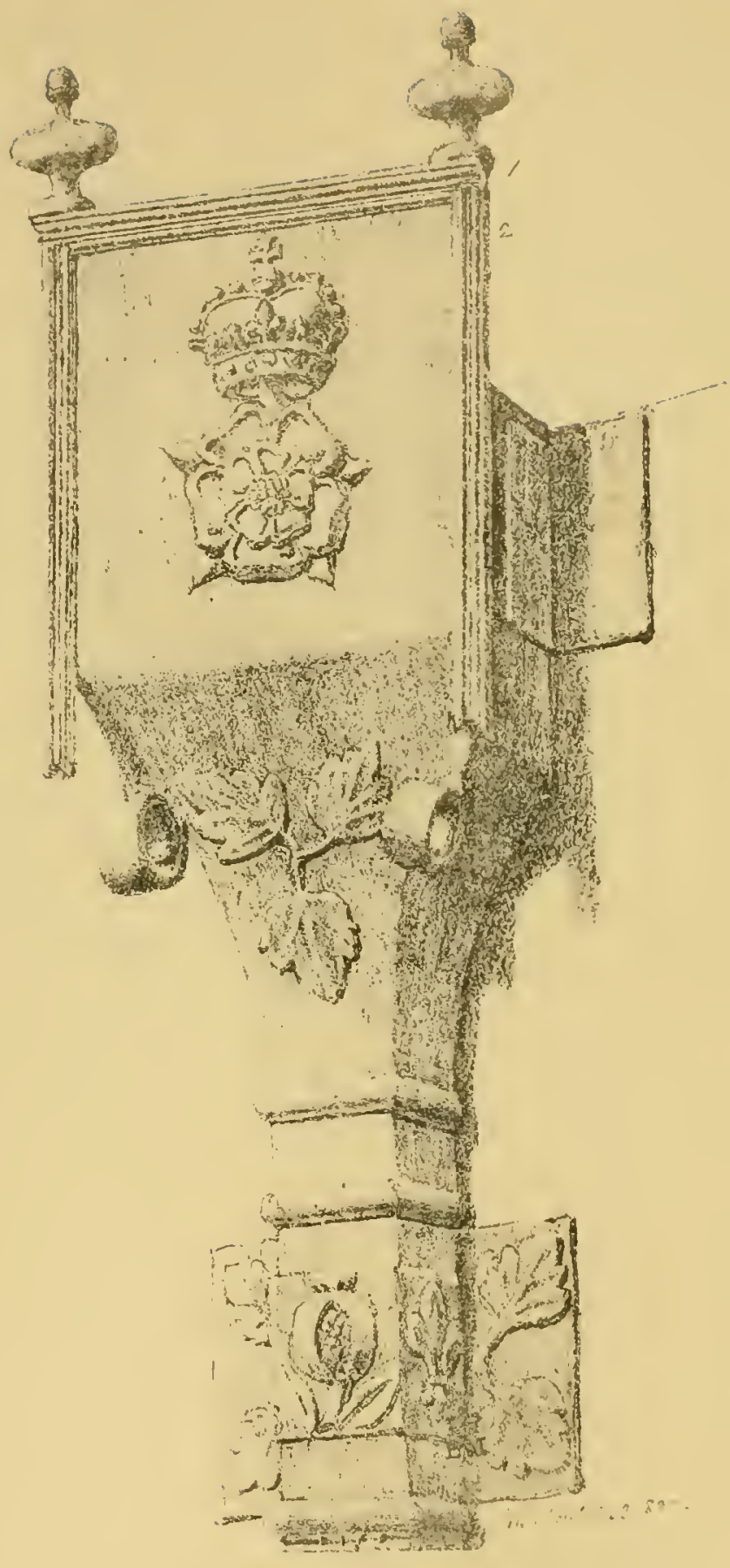

II. RAINWATER PIPE-HEAD DOME ALLEY, WINCHESTER. 


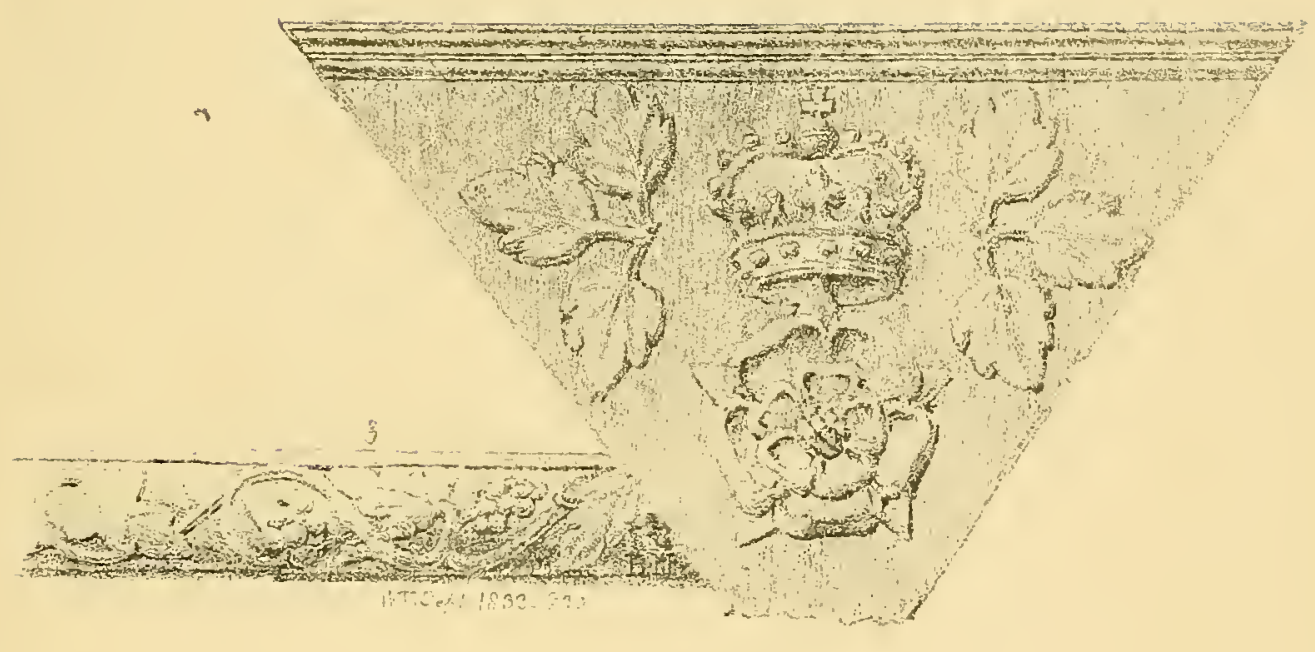

III. GUtTER AND FLASHing, DOME ALLEY, WINCHESTER. 



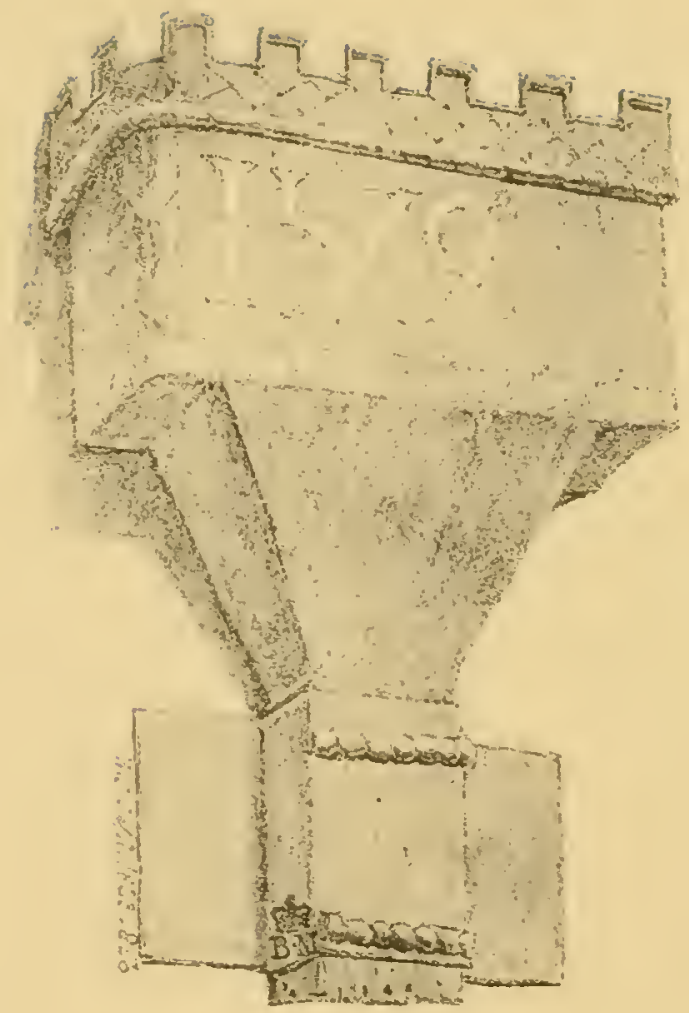

IV. RAINWATER PIPE-HEAD, SHERBORNE, DORSET 


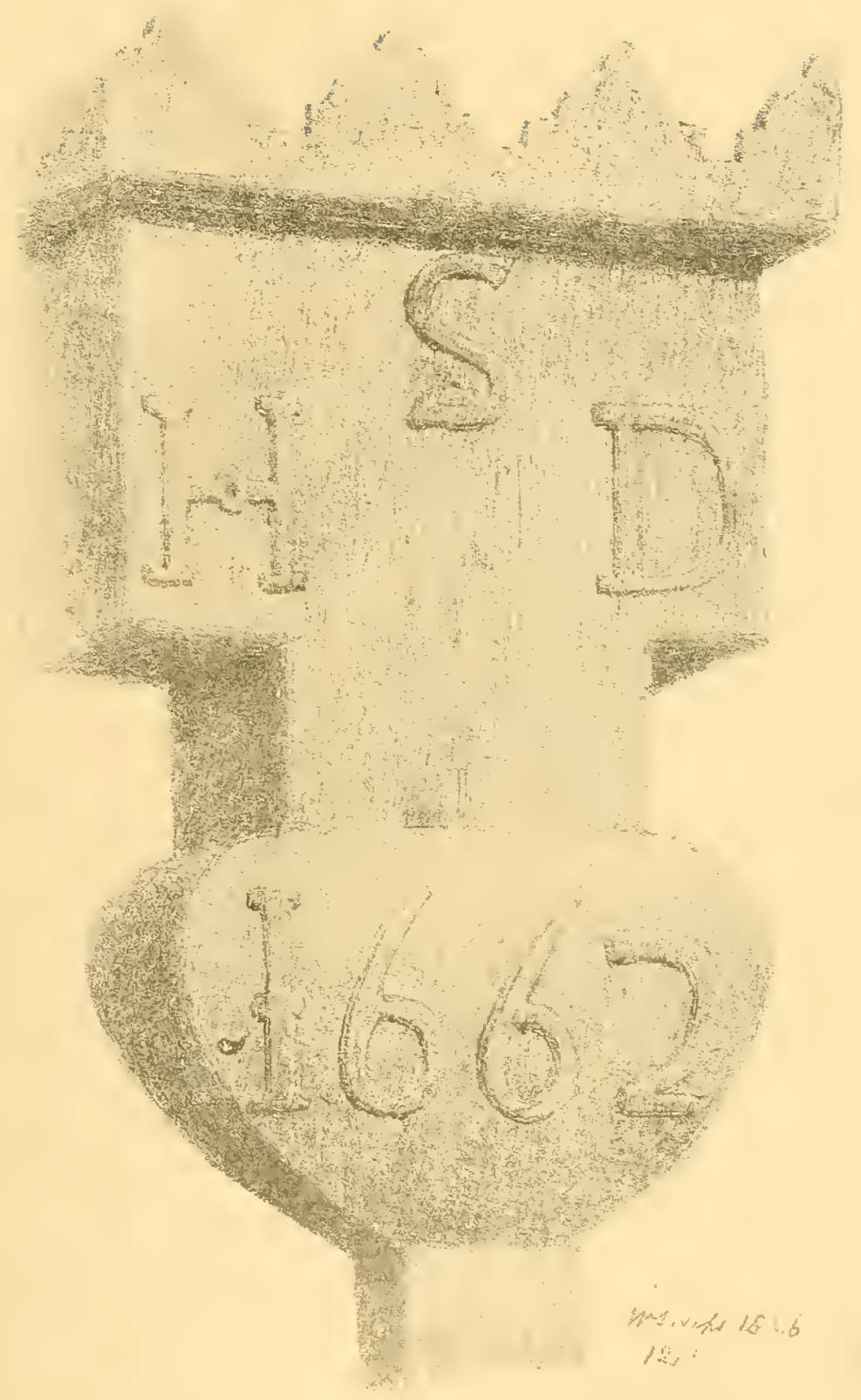

V. RAINWATER PIPE-HEAD, STAIWICK. VORKSHIRE, 



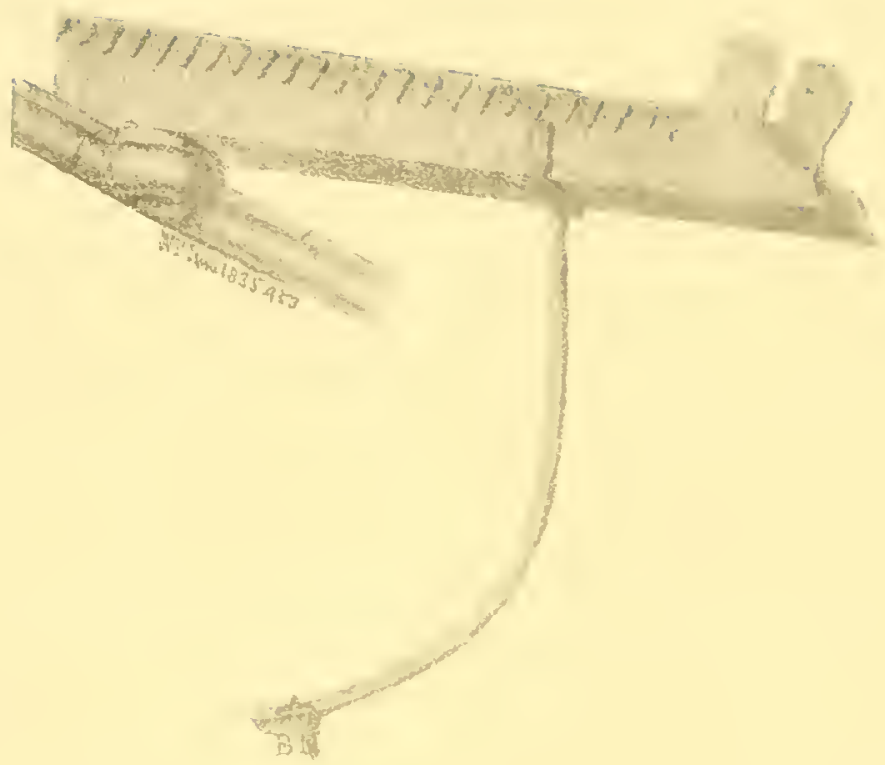

GARGUYLE WITH BRACHET, UFFINGTON CHU - H, LINI LADH 


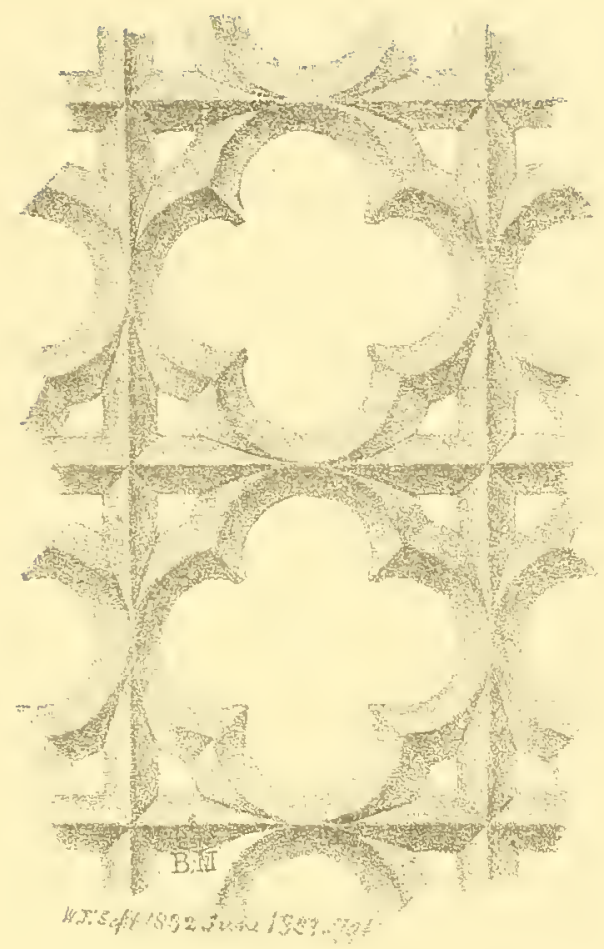

VII. OPEN LEADWORK, STAIRCASE WINDOW, OXBURGH HALL, NORFOLK. (FULL SIZE.) 



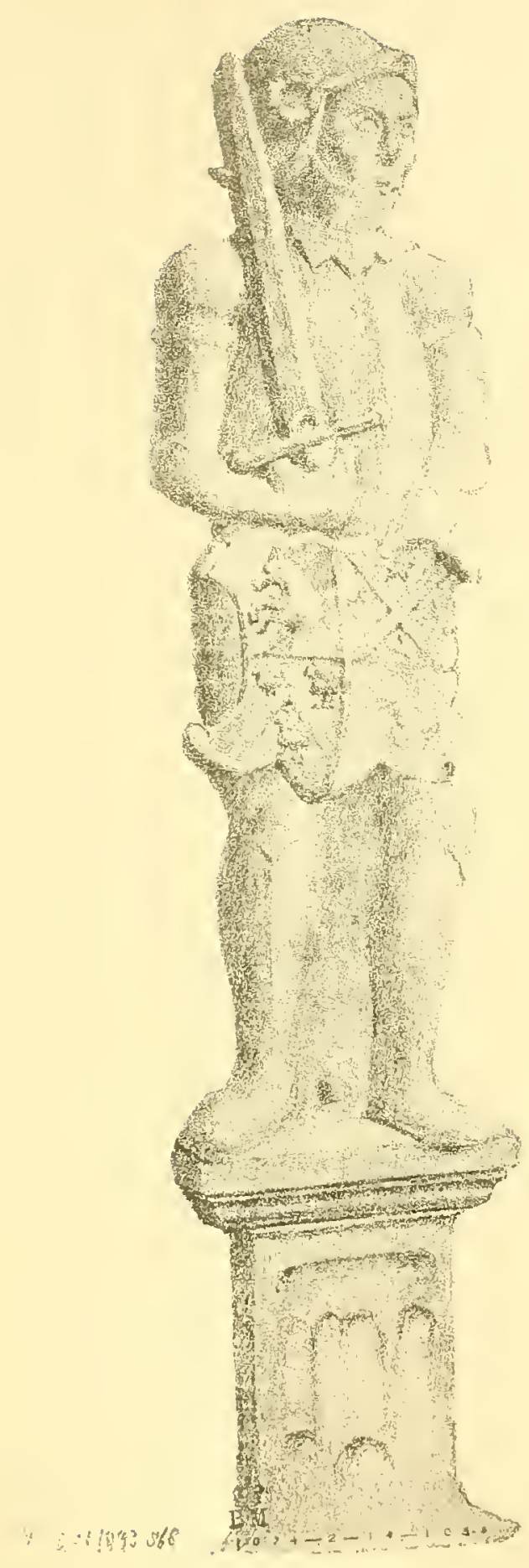

IX. FIRE-DOG, NETTLECOMBE COURT, SOMERSETSHIRE 


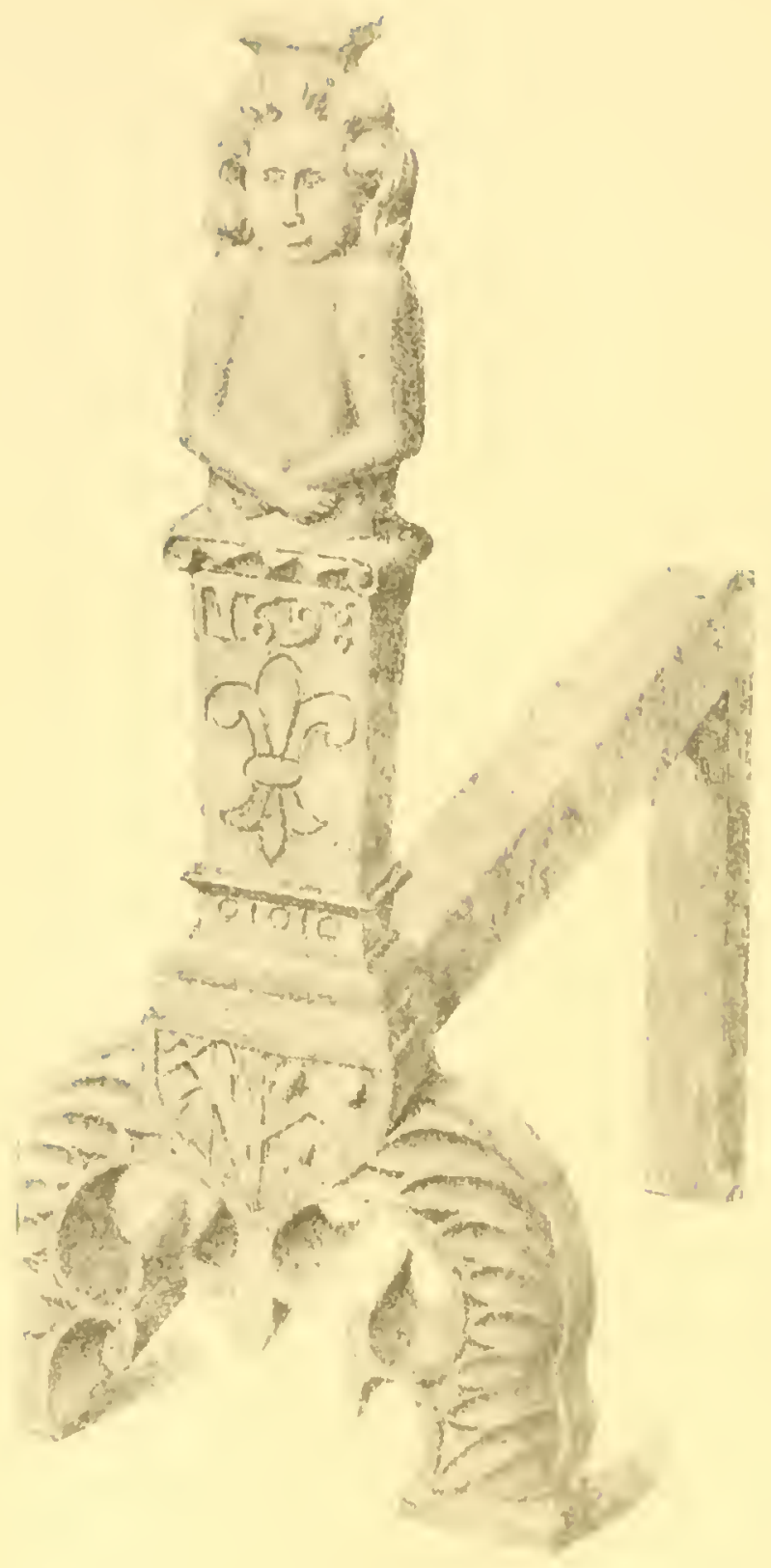




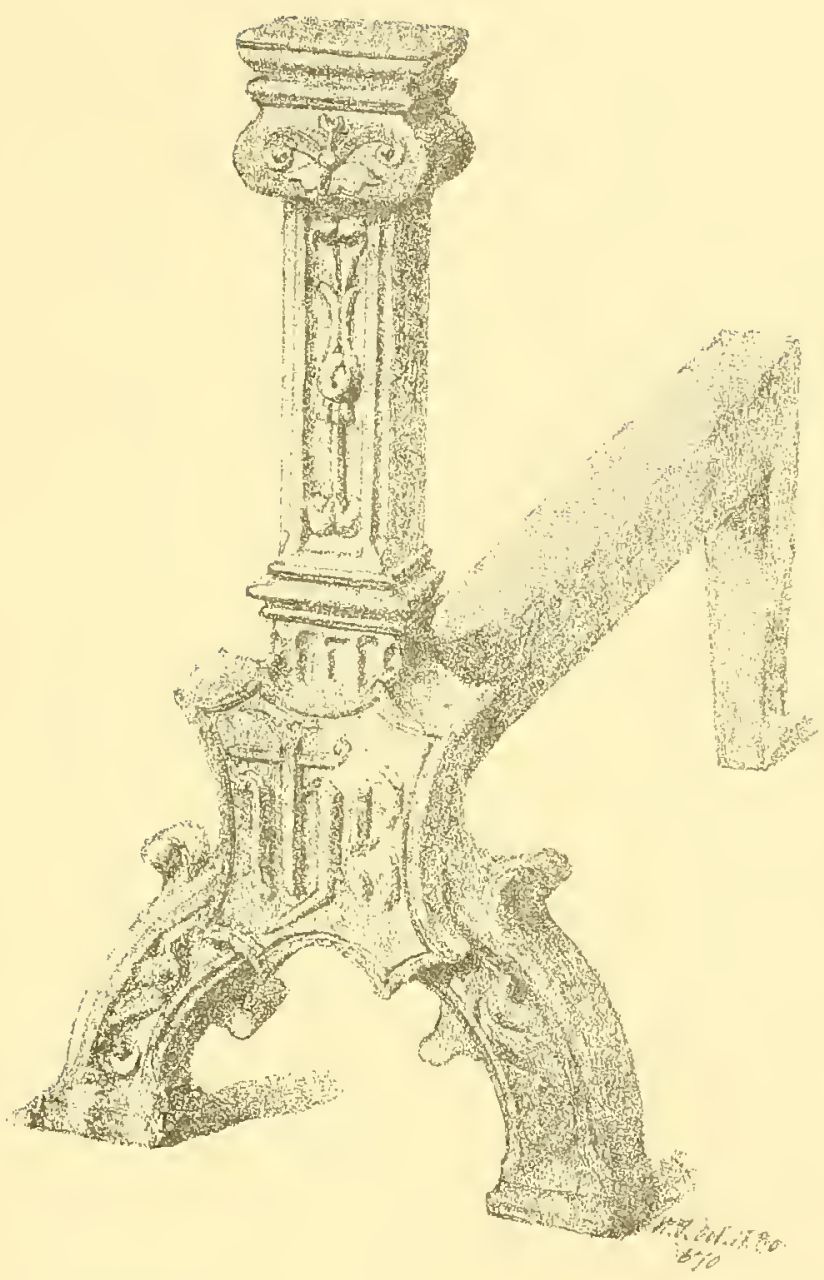

XI. FIRE-DOG, GODINTON, KENT 


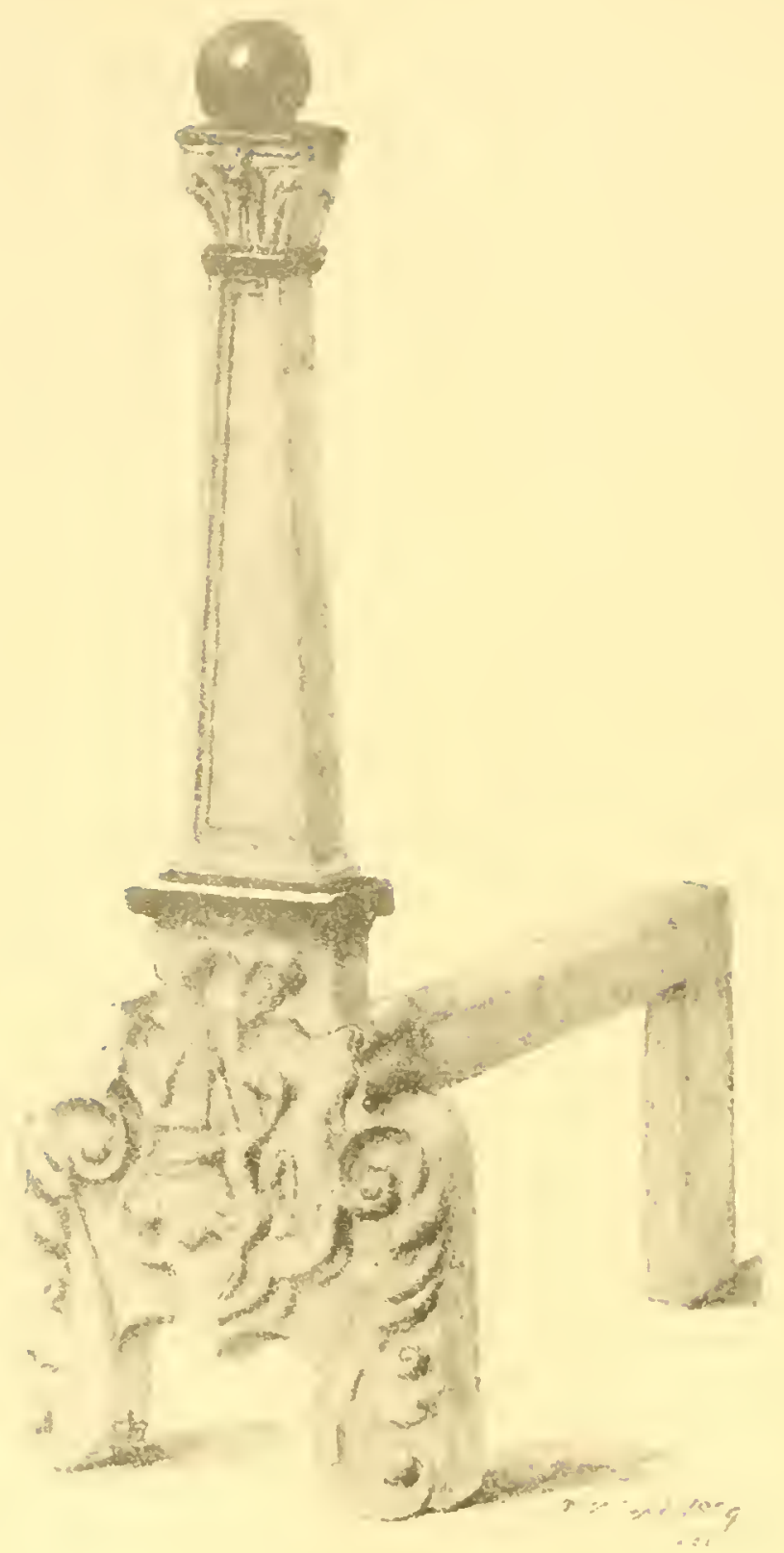

XI1. FIRE-DOG, GILSTON PARK, HERTFORDSHIRE 


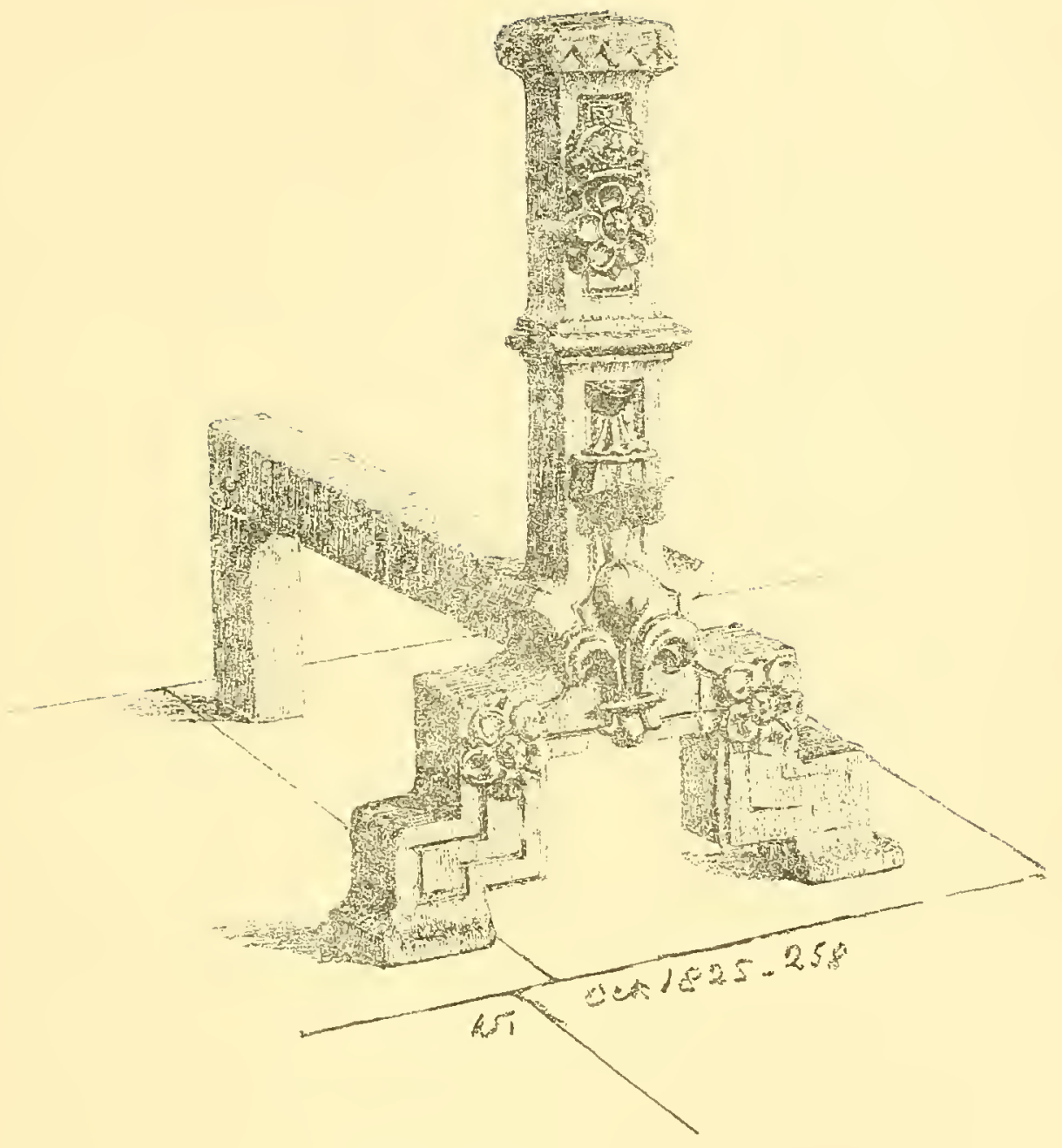

XIII, FIRE-DOG, LEEDS CASTLE, KENT. 


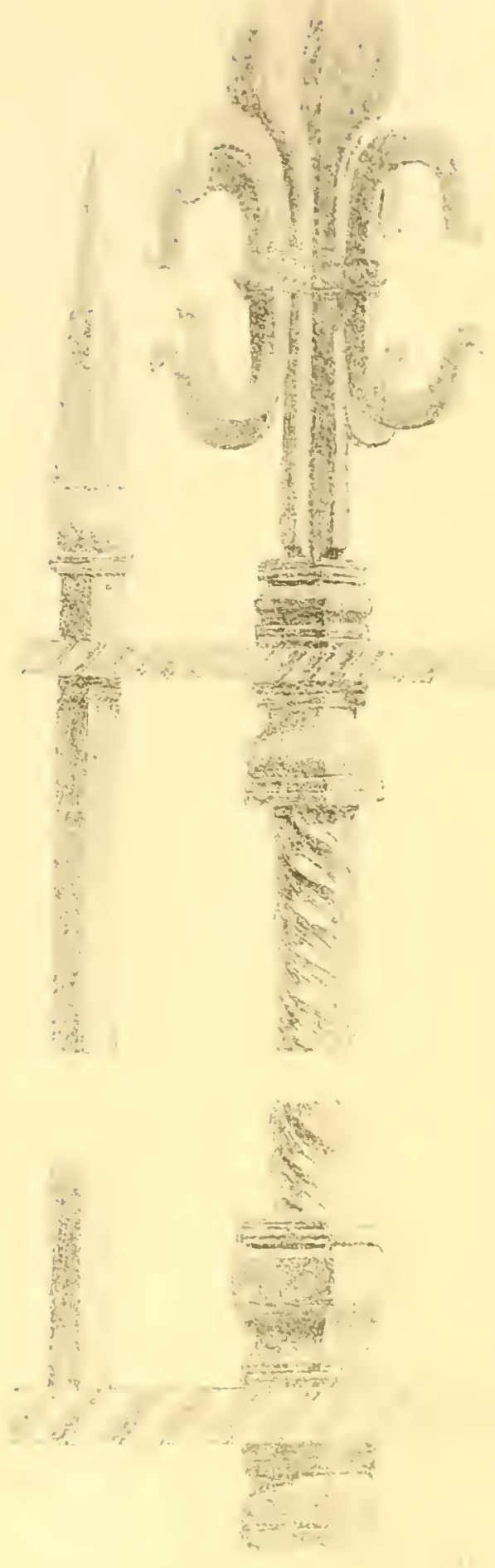

IV RAILING STANDARD, SIR HUGH SMITHSONS TOMB, STANWICK YLRKSHIRE 

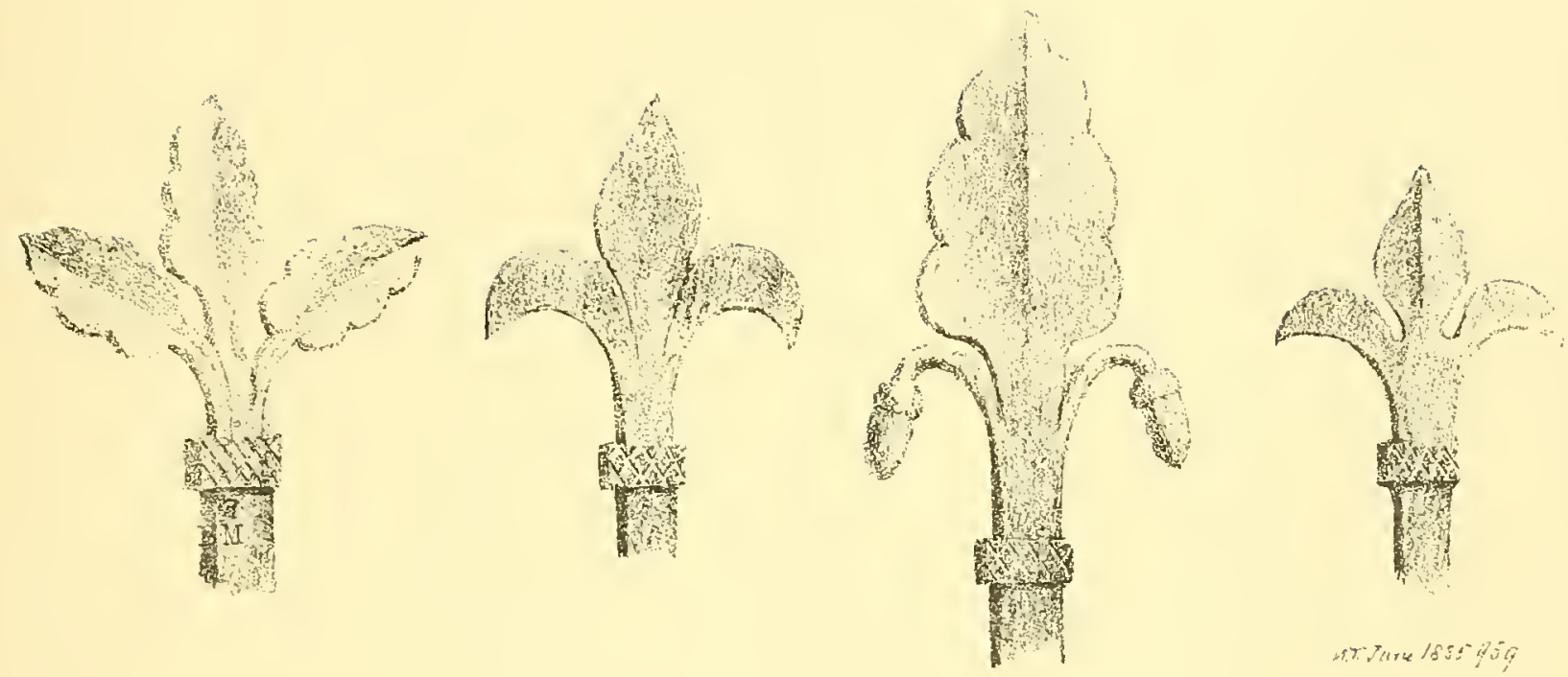

XV. RAILING STANDARDS, EYWORTH CHURCH, BEDFORDSHIRE 


$$
t+t
$$




$$
\frac{1}{t} d
$$




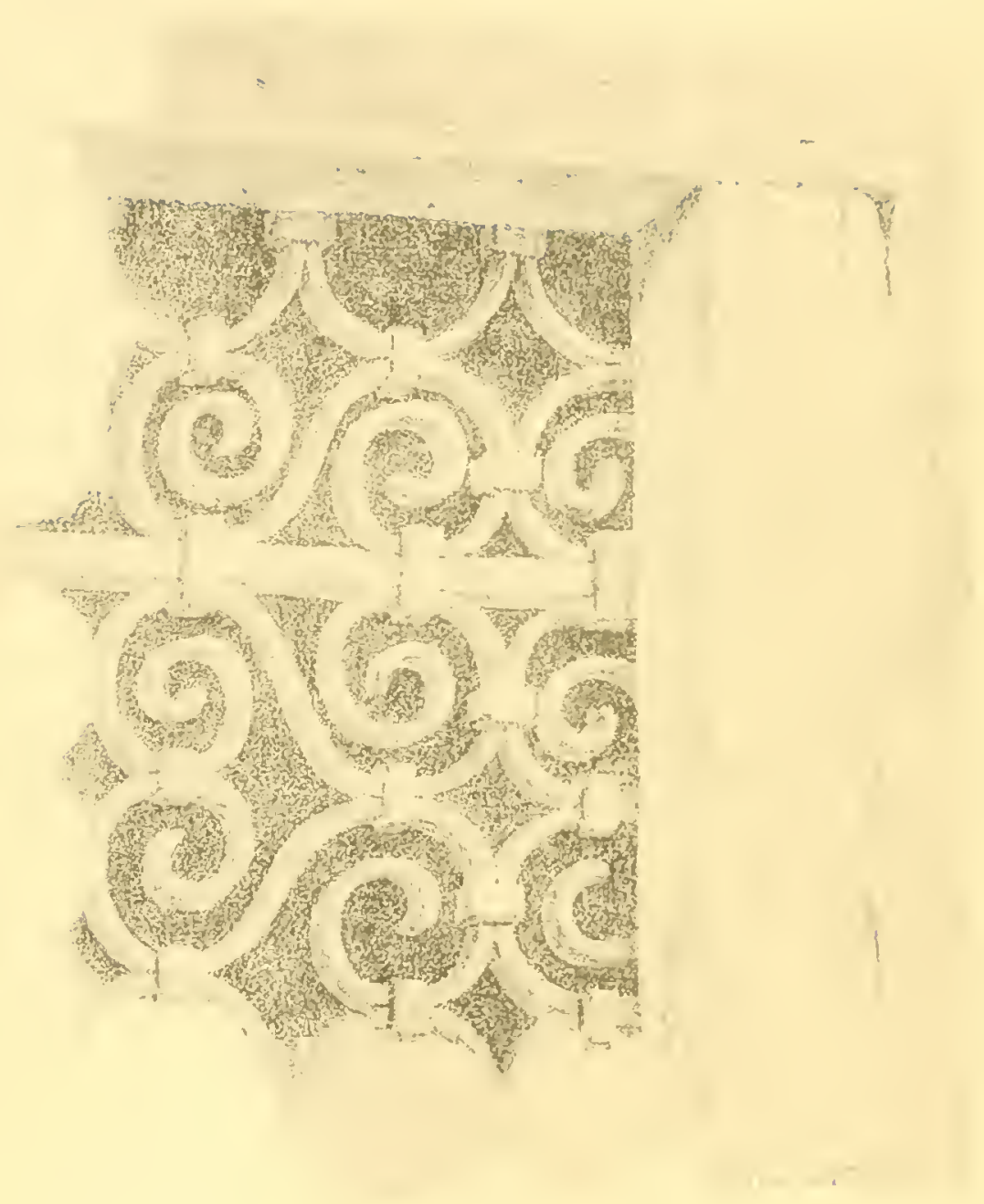

XYIII GRILLE OF DAIRY WINDUW, ULCOMBE, K.ENT 


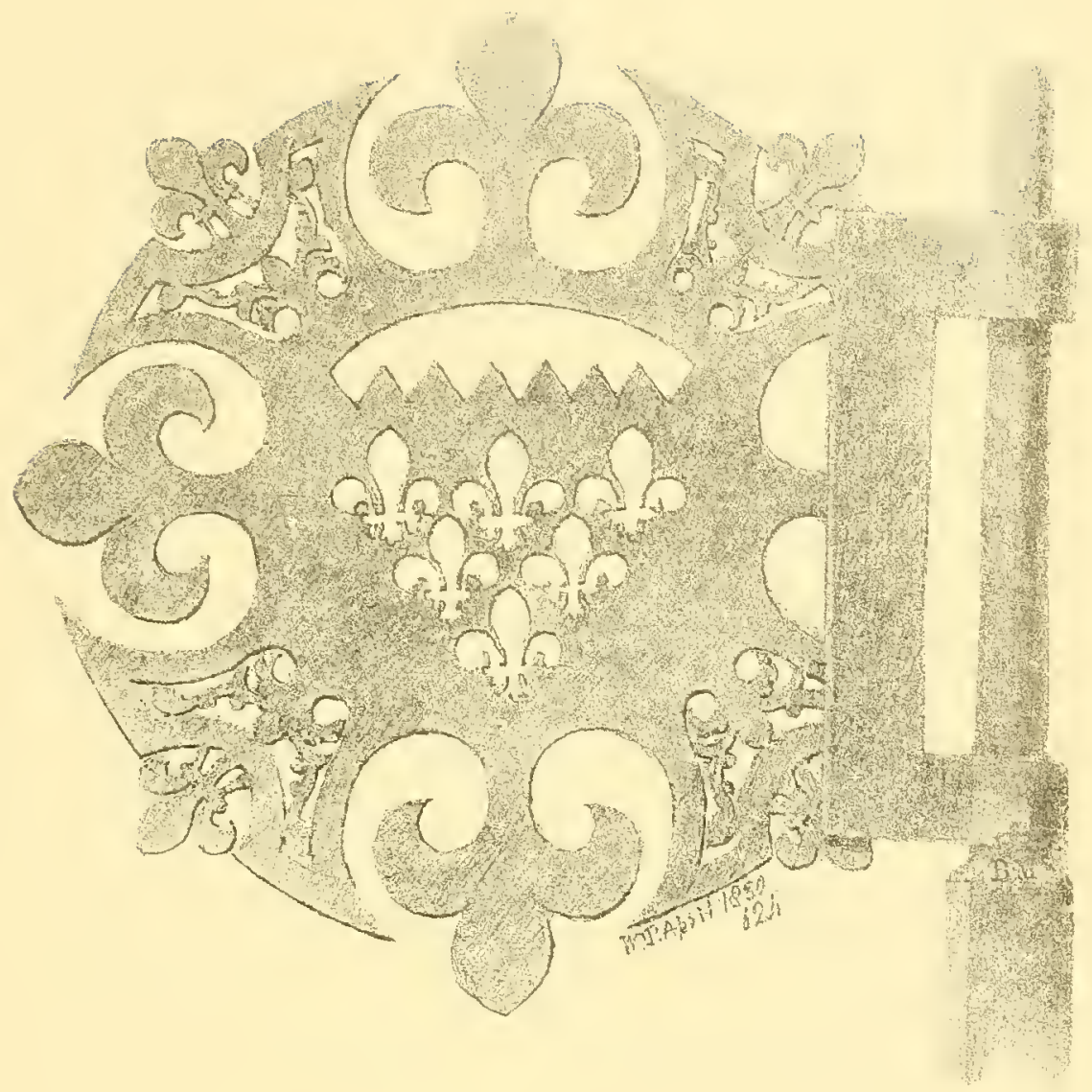

XIX, VANE, OXBURGH HALL, NORFOLK 



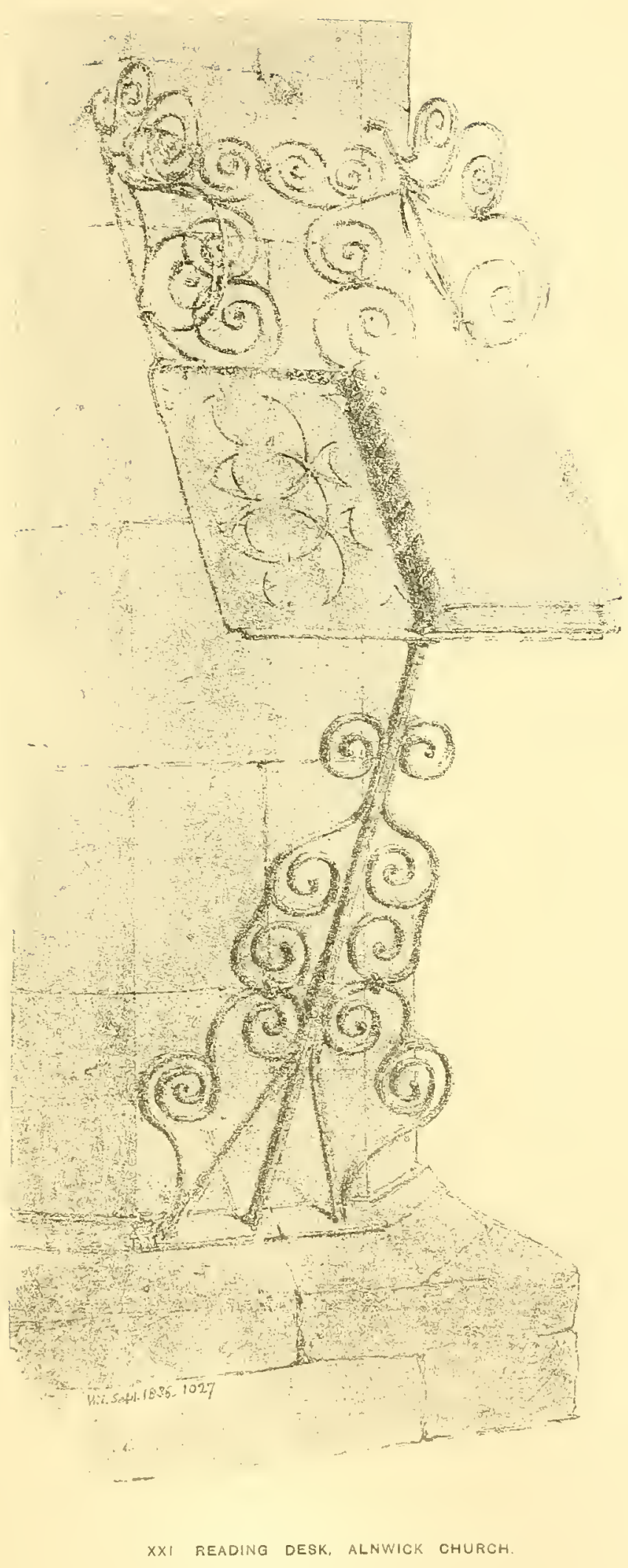





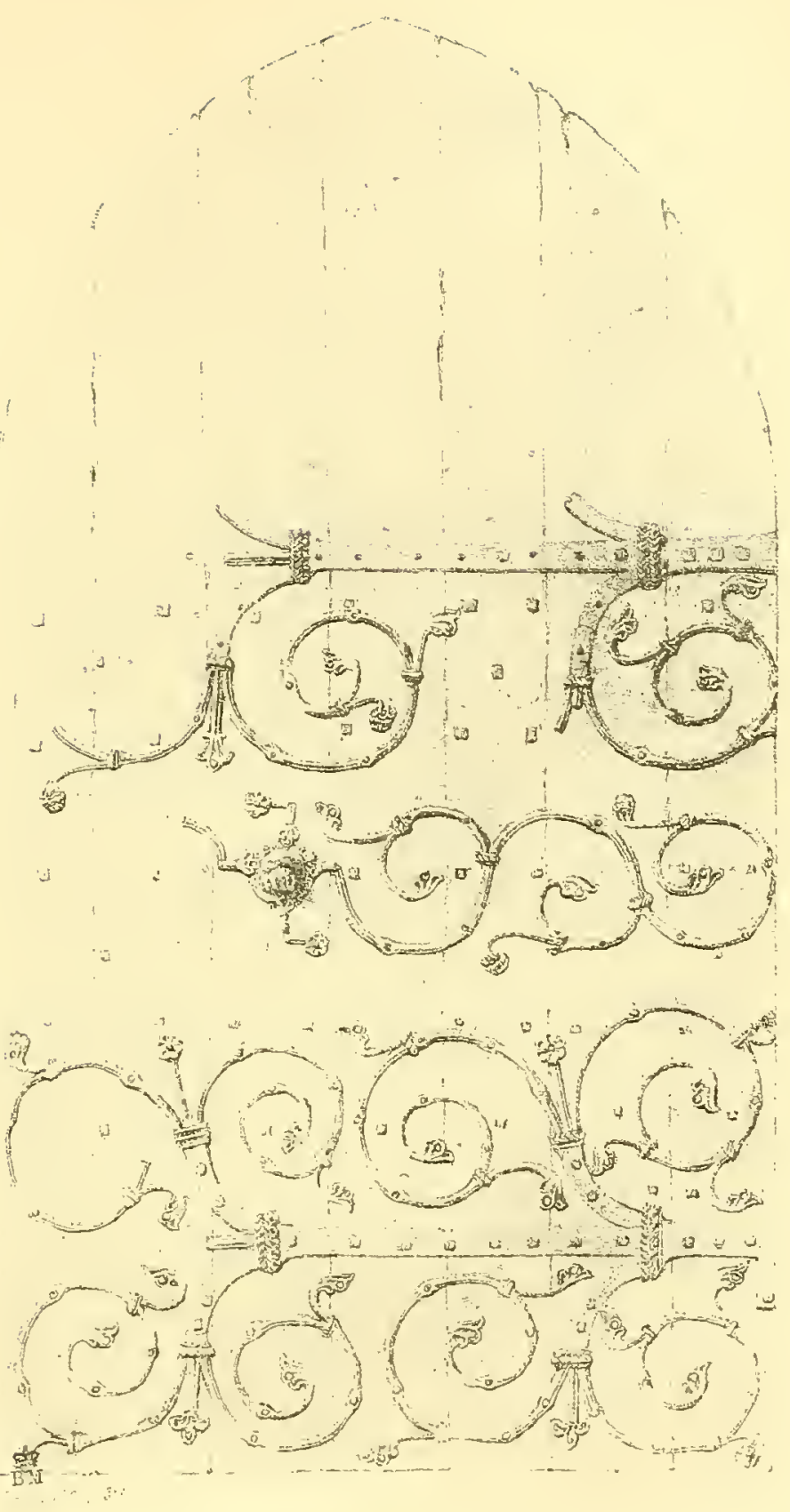

XXIII, HINGE-STRAPS ON WEST DOOR, LEIGHTON BUZZARD CHURCH, BEDFORDSHIRE. 


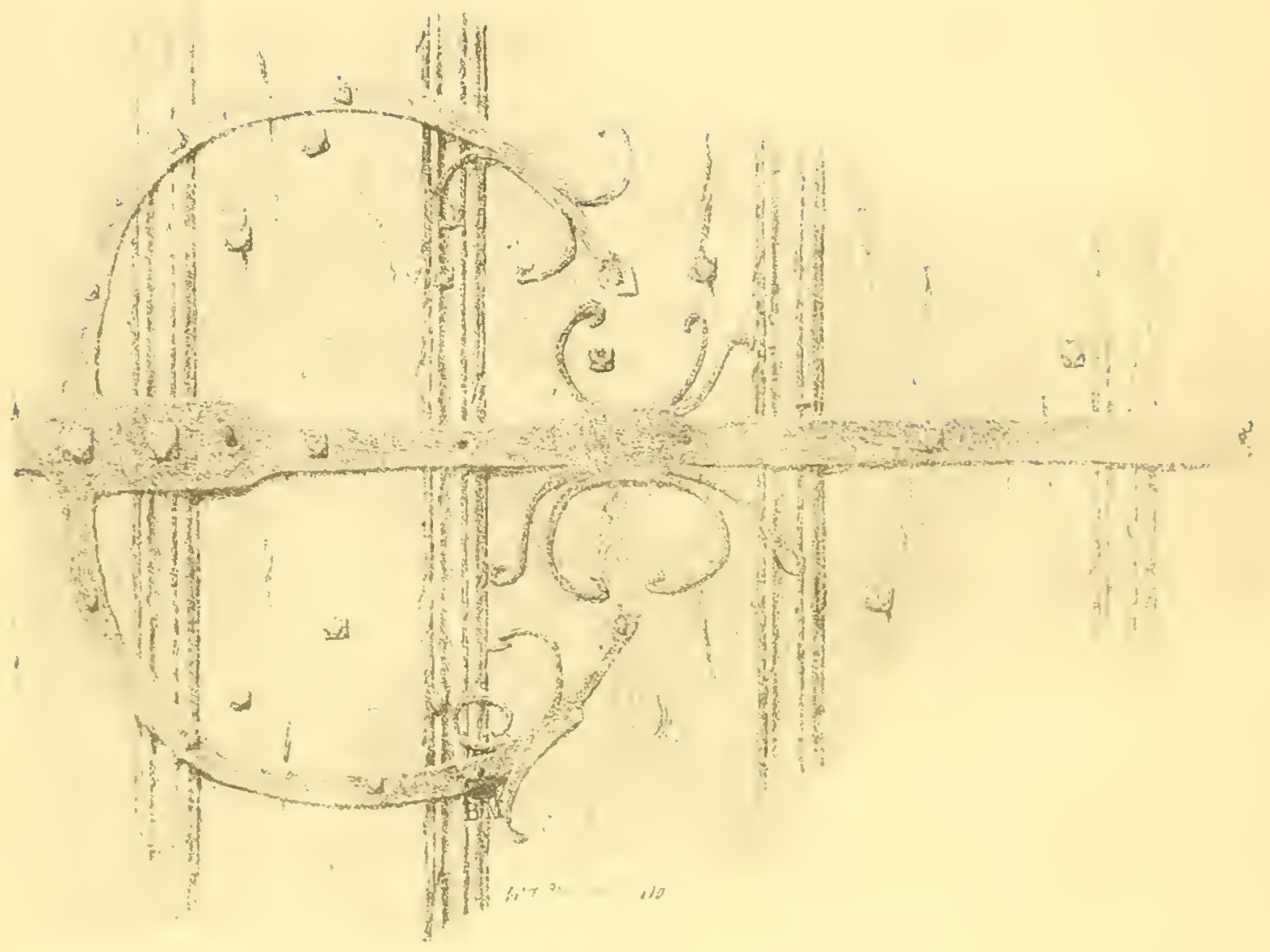

XMIV HINGE-STRAP ON SOUTH DOOR OF CHURCH. HOUGH OP THE-HILL. LIICOLNSHIRE 


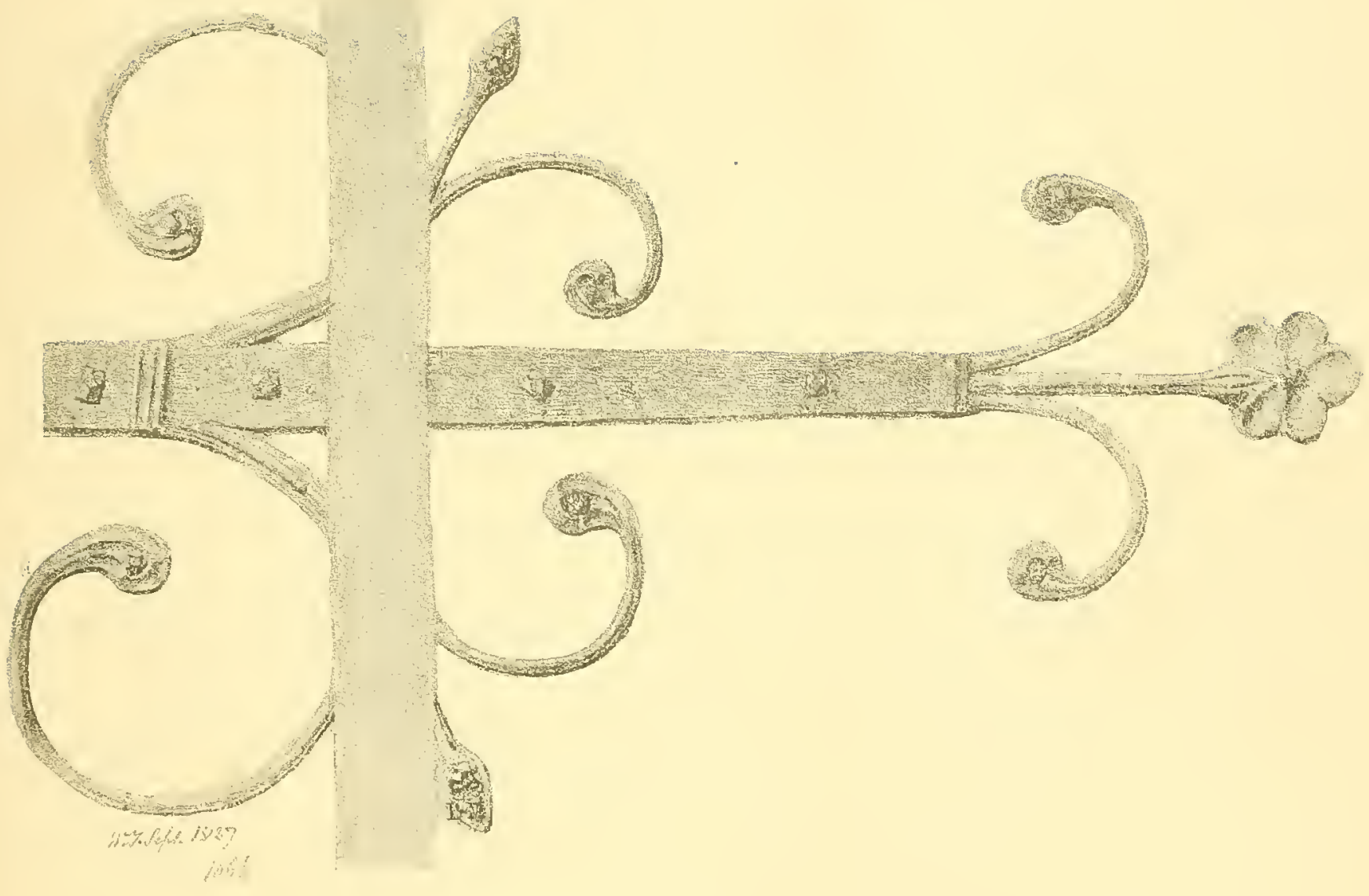

XXV. HINGE-STRAP, CHACOMBE CHURCH, NORTHANTS. 
<smiles>[Te]</smiles> 


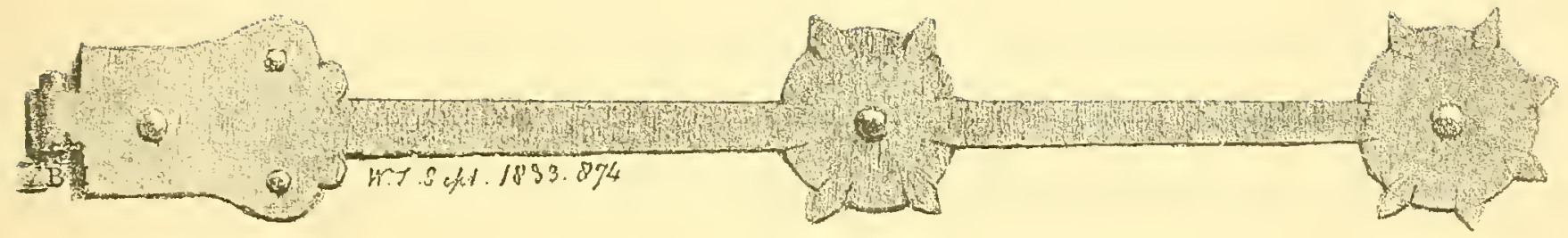

XXVII. HINGE, GLASSES, SOMERSET. 


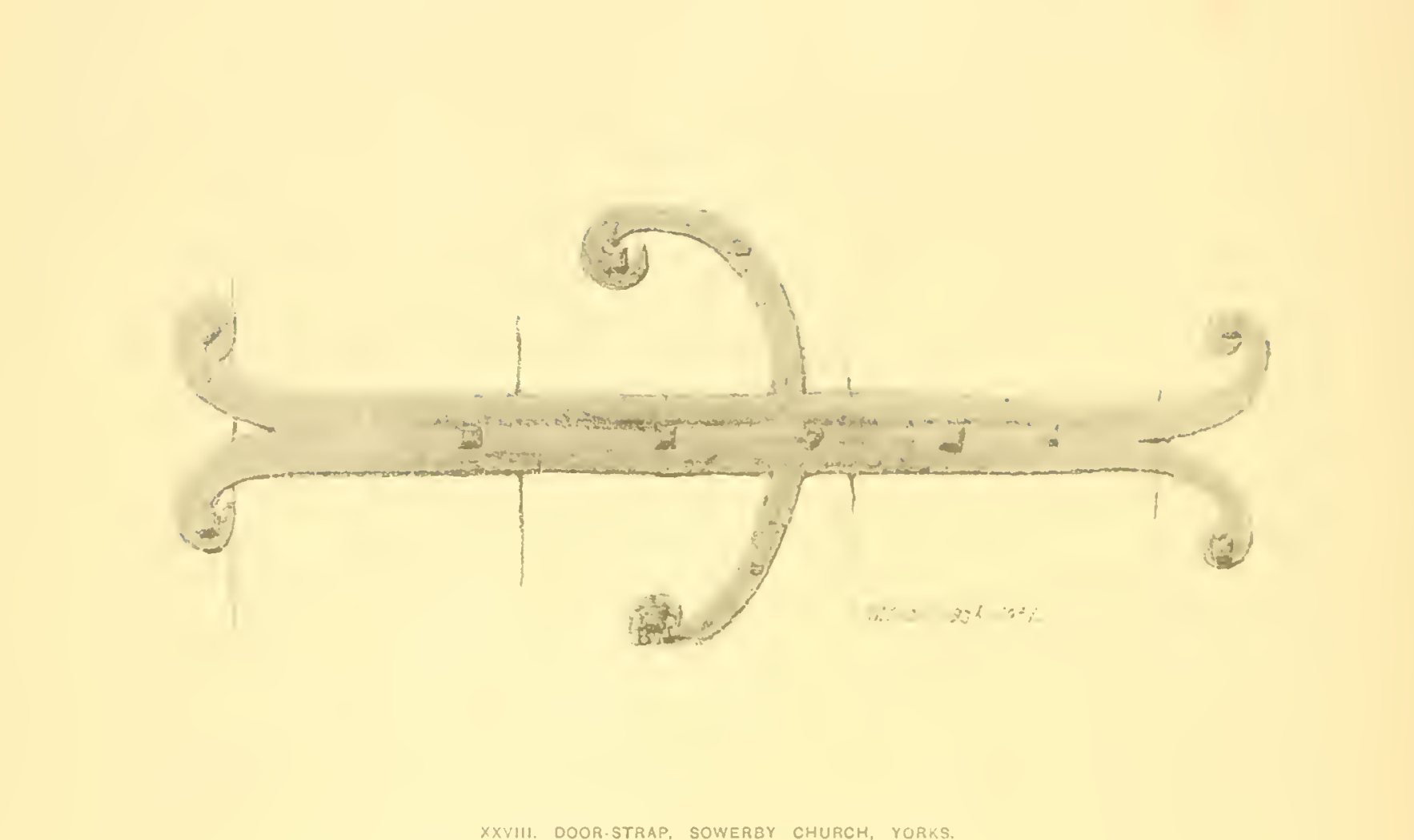




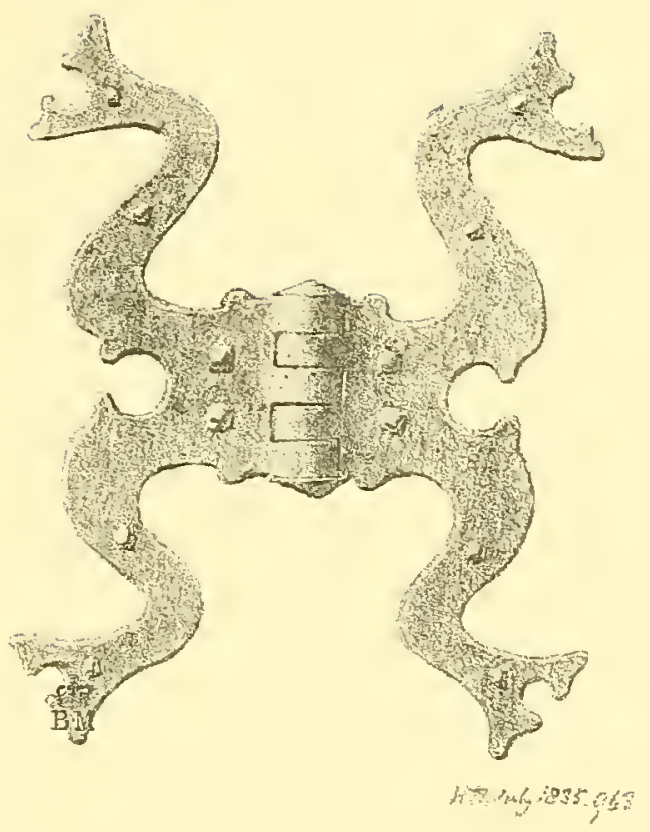

XXIX. HINGE, BOUGHTON MALHERBE, KENT. 


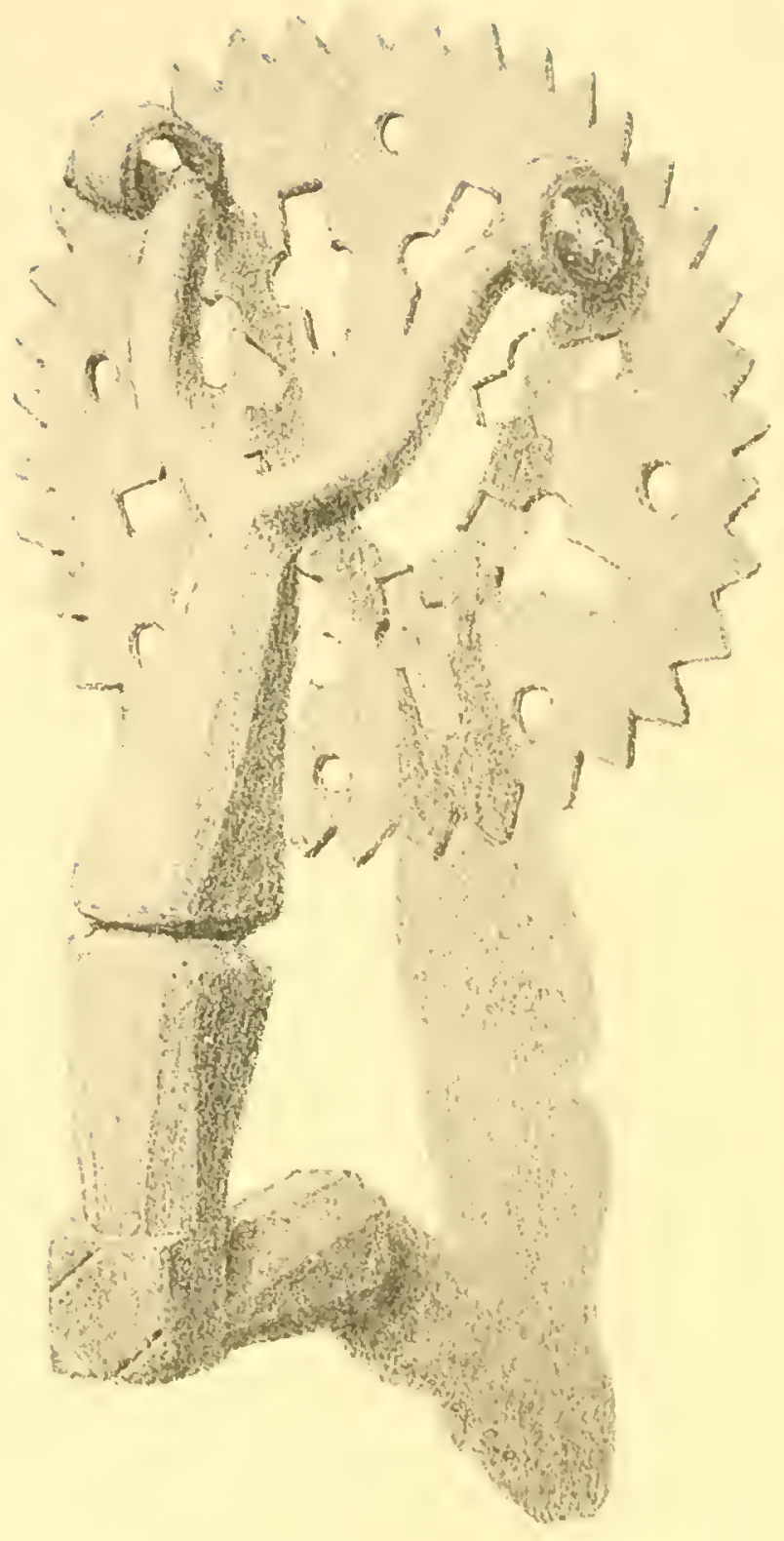

XXX, KNOCKER, STOCKBURY VICARAGE, KENT, 


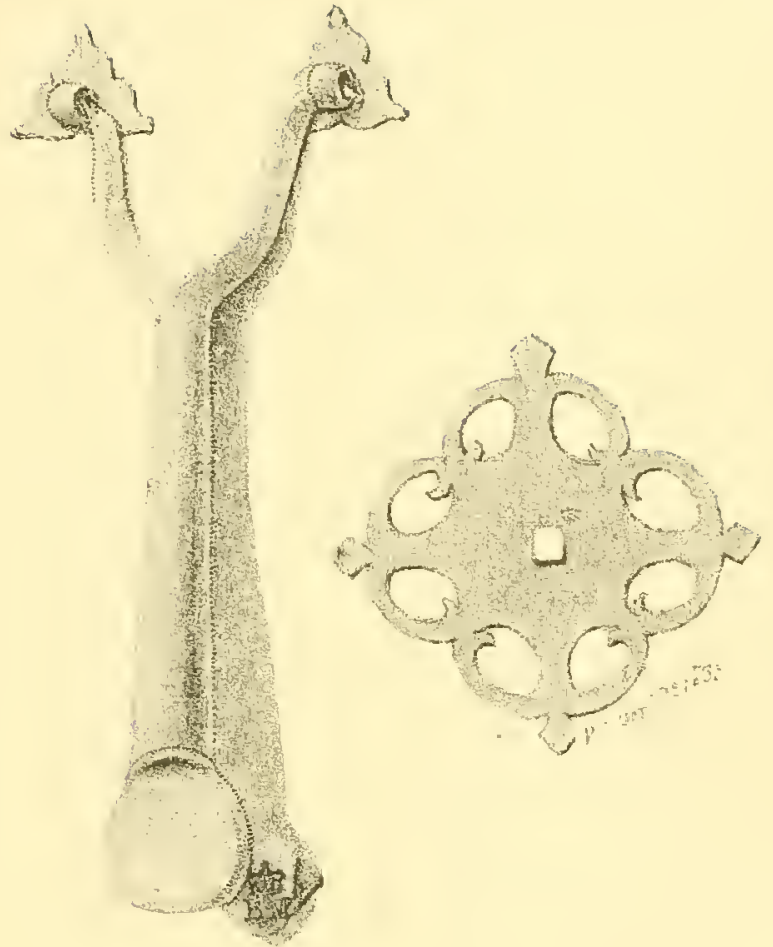

XXXI. KNOCKER AND ROSE OF HANDLE, ANGEL INN, LACOCK, WILTS. 


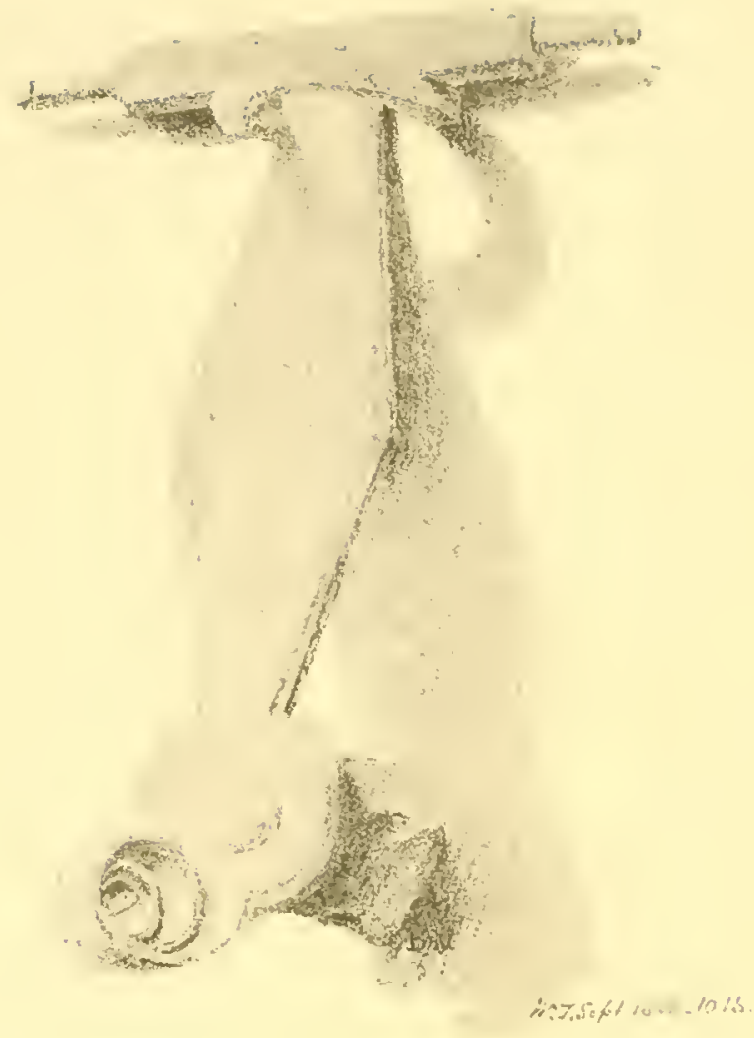

XXXII. KNOCKER, KIRKBRIDGE, STANWICK, YORKS, 


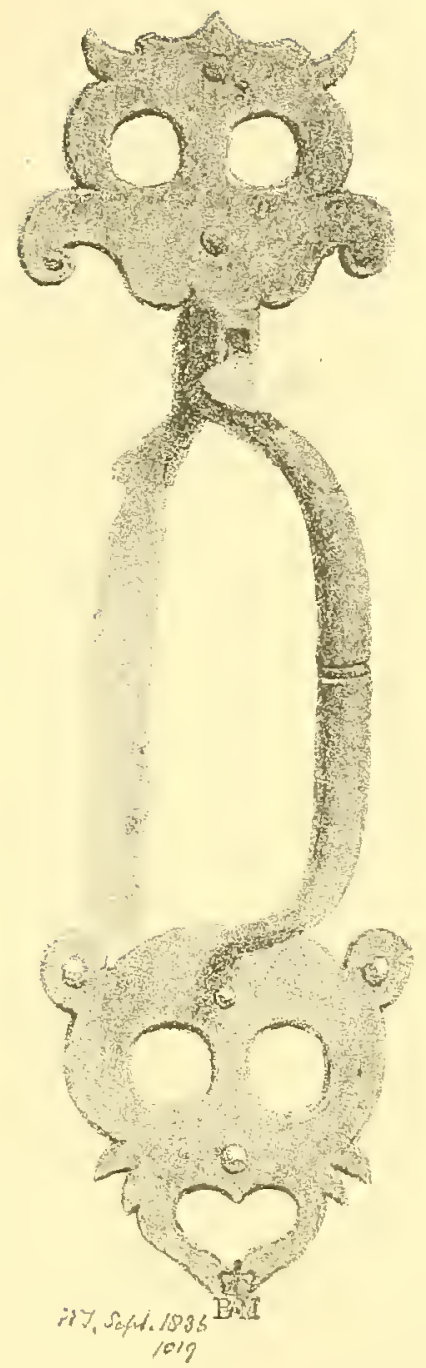

XXXIII. HANDLE FOR LATCH. ATHELSTANE ABBEY, YORKS. 


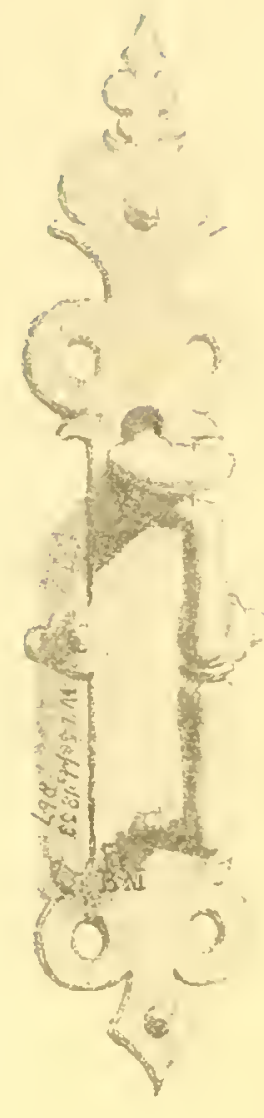

XXXIV. NORFOLK LATCH, WOKEY, SOMERSET. 


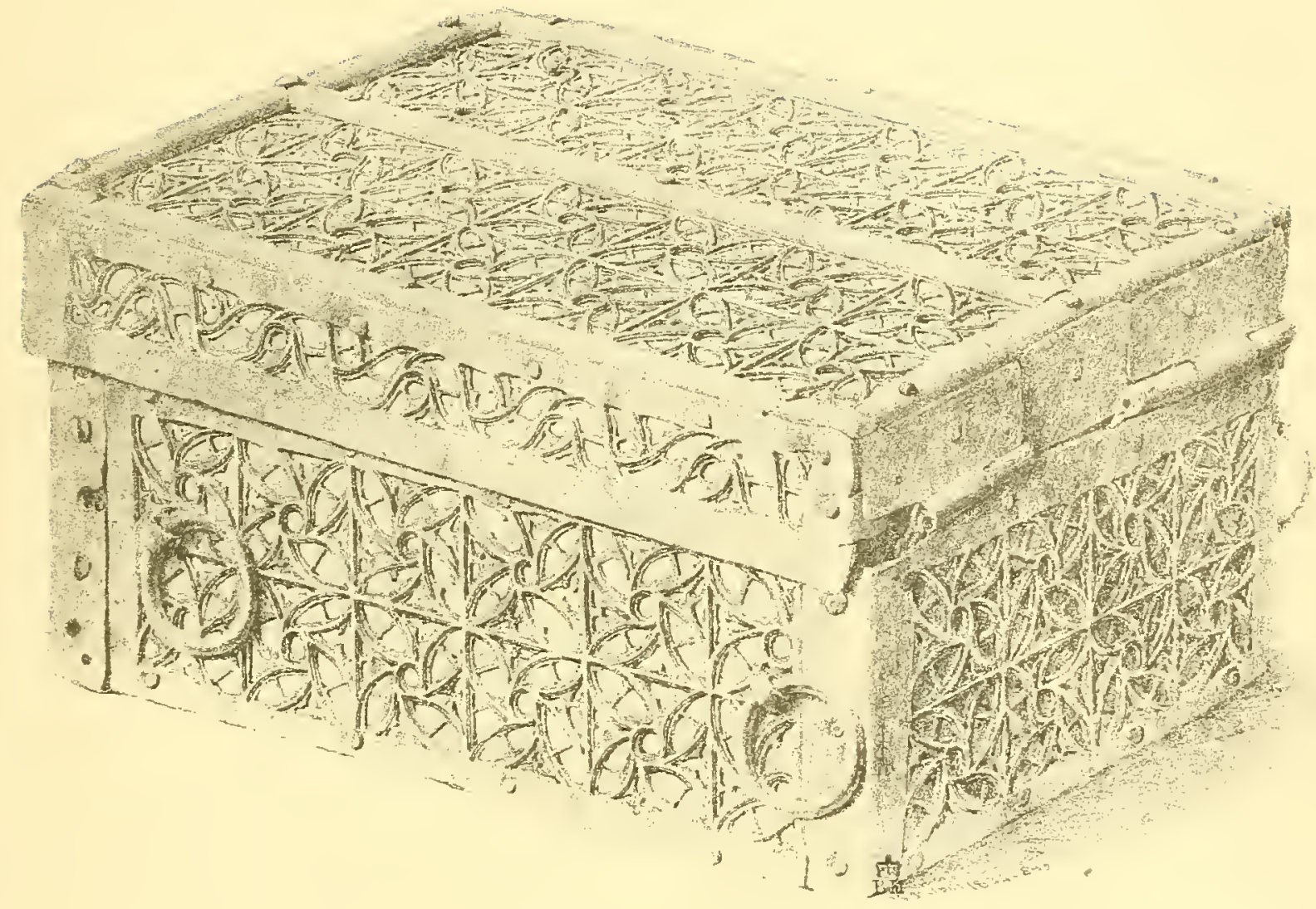

XXXY, IRON BOX IN THE POSSESSION OF THE HON. ELIZABETH CUST. 


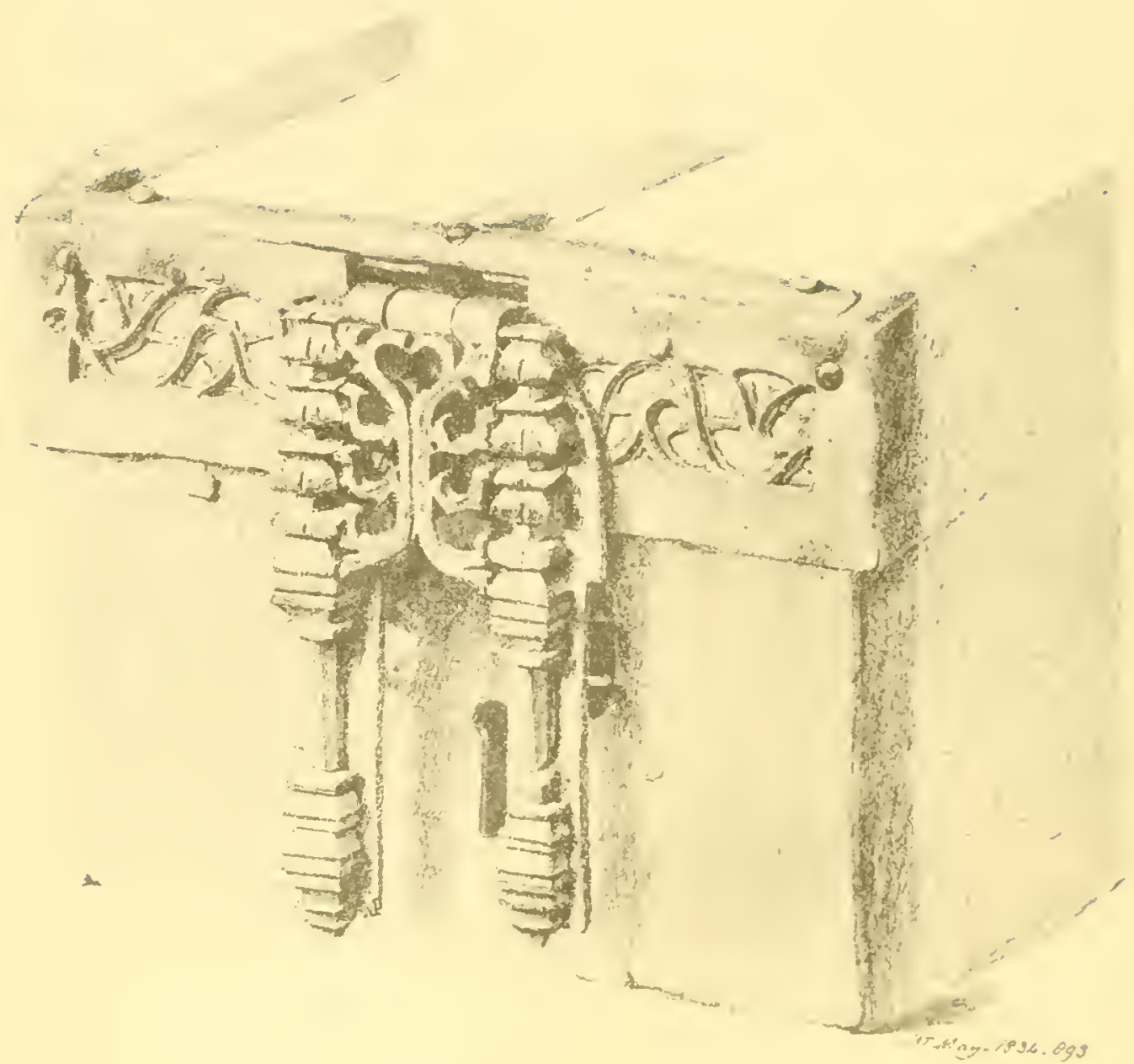

XYY LOCK AND HASP OF IRON BOX IN MISS CUST'S POSSESSION. 


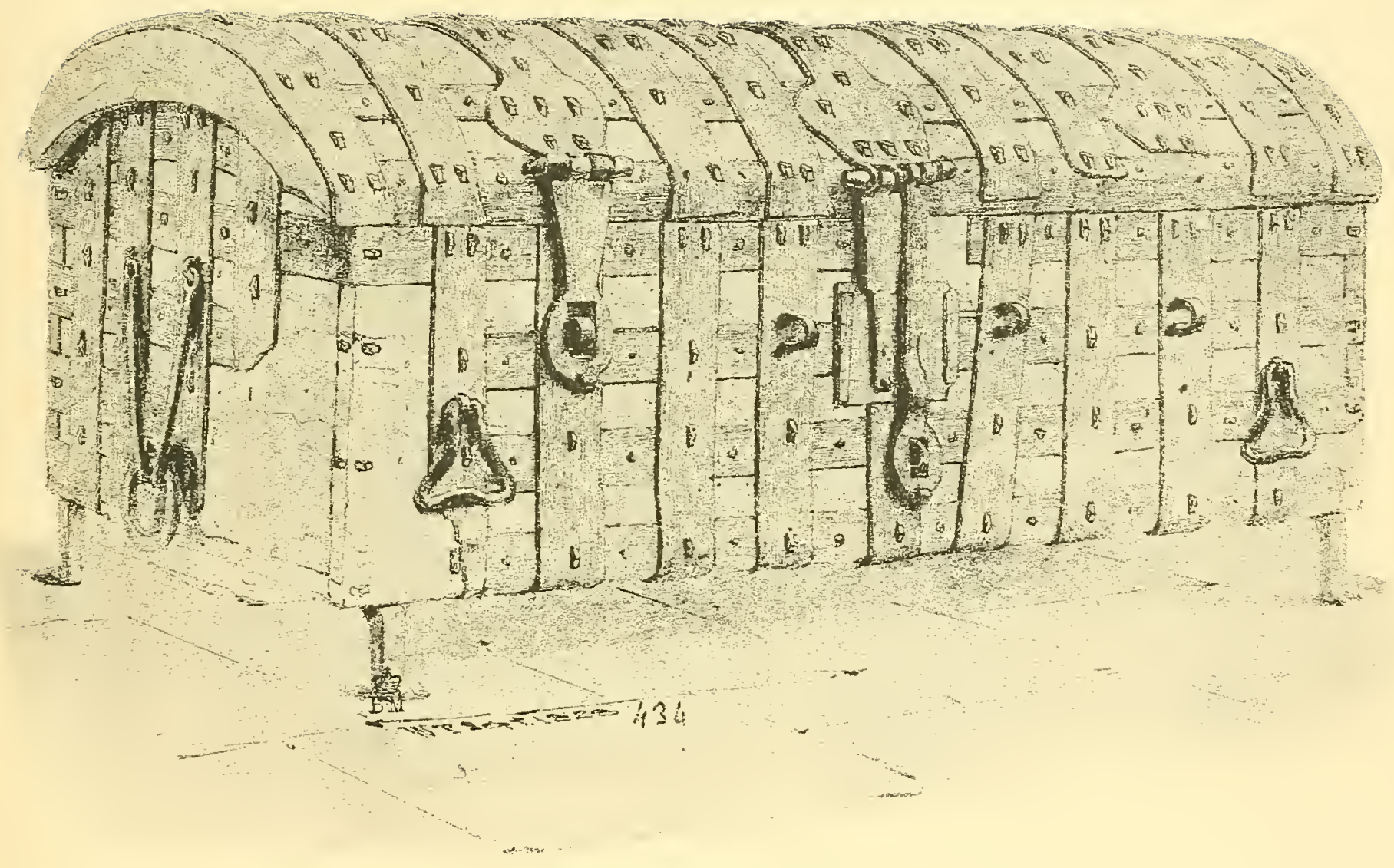

XXXVII, CHEST, WITH IRON FITTINGS, NORTHFLEET CHURCH, KENT 


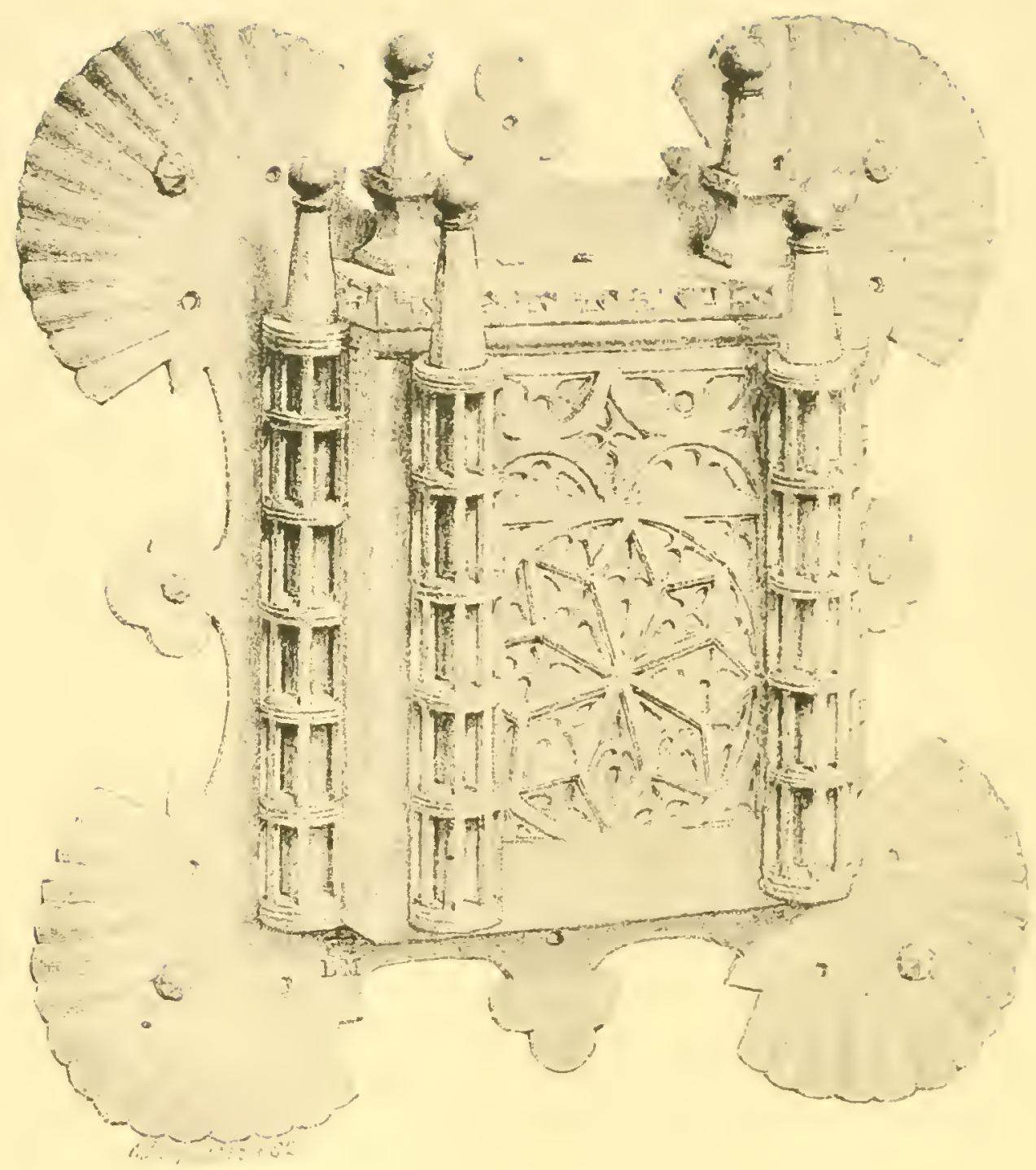

XXXVIII. LOCK ON CHEST, NETTLECOMBE, COURT, SOMERSET. 


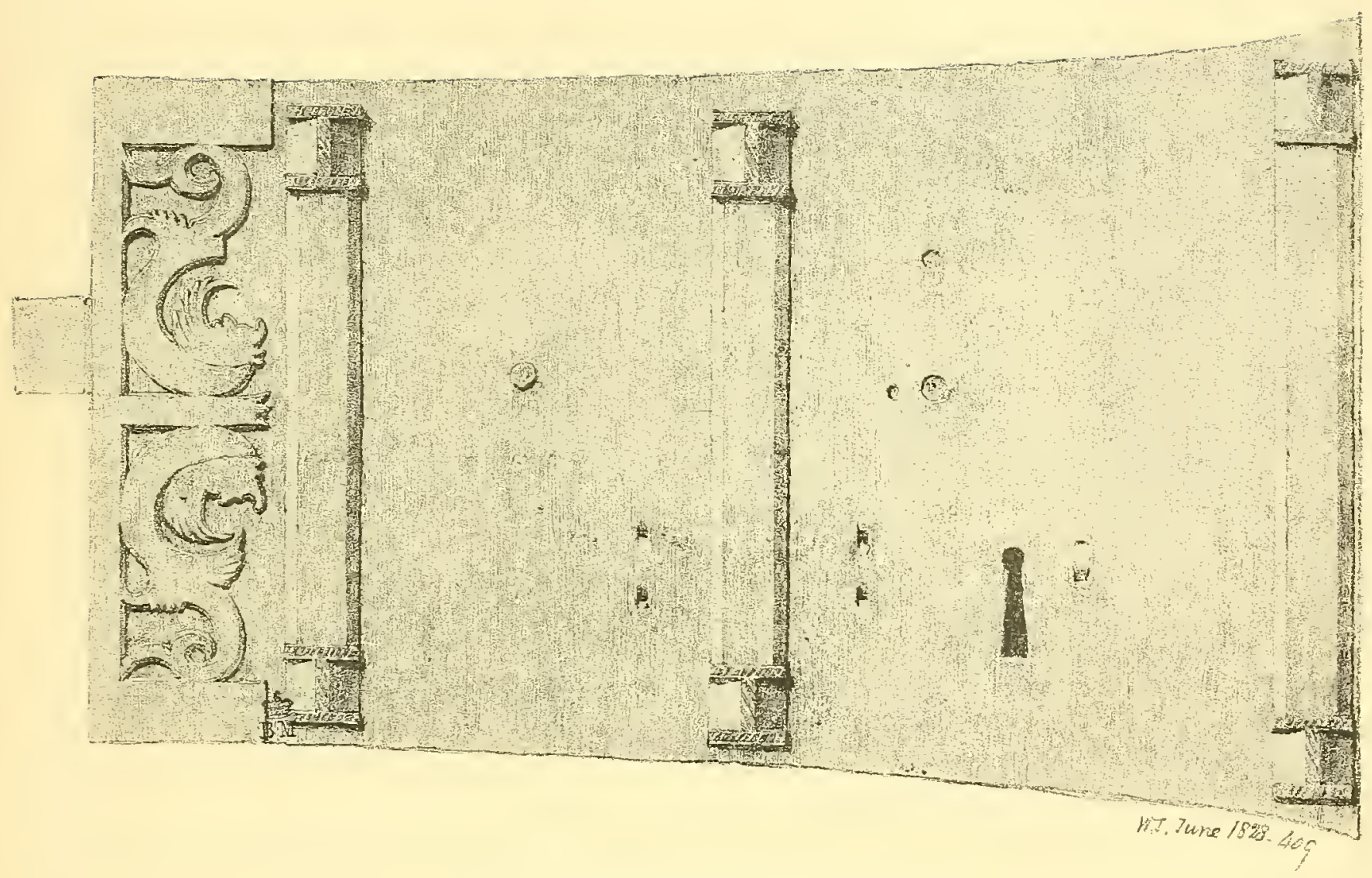

XXXIX, LOCK, EASTBURY HOUSE, BARKING, ESSEX, 


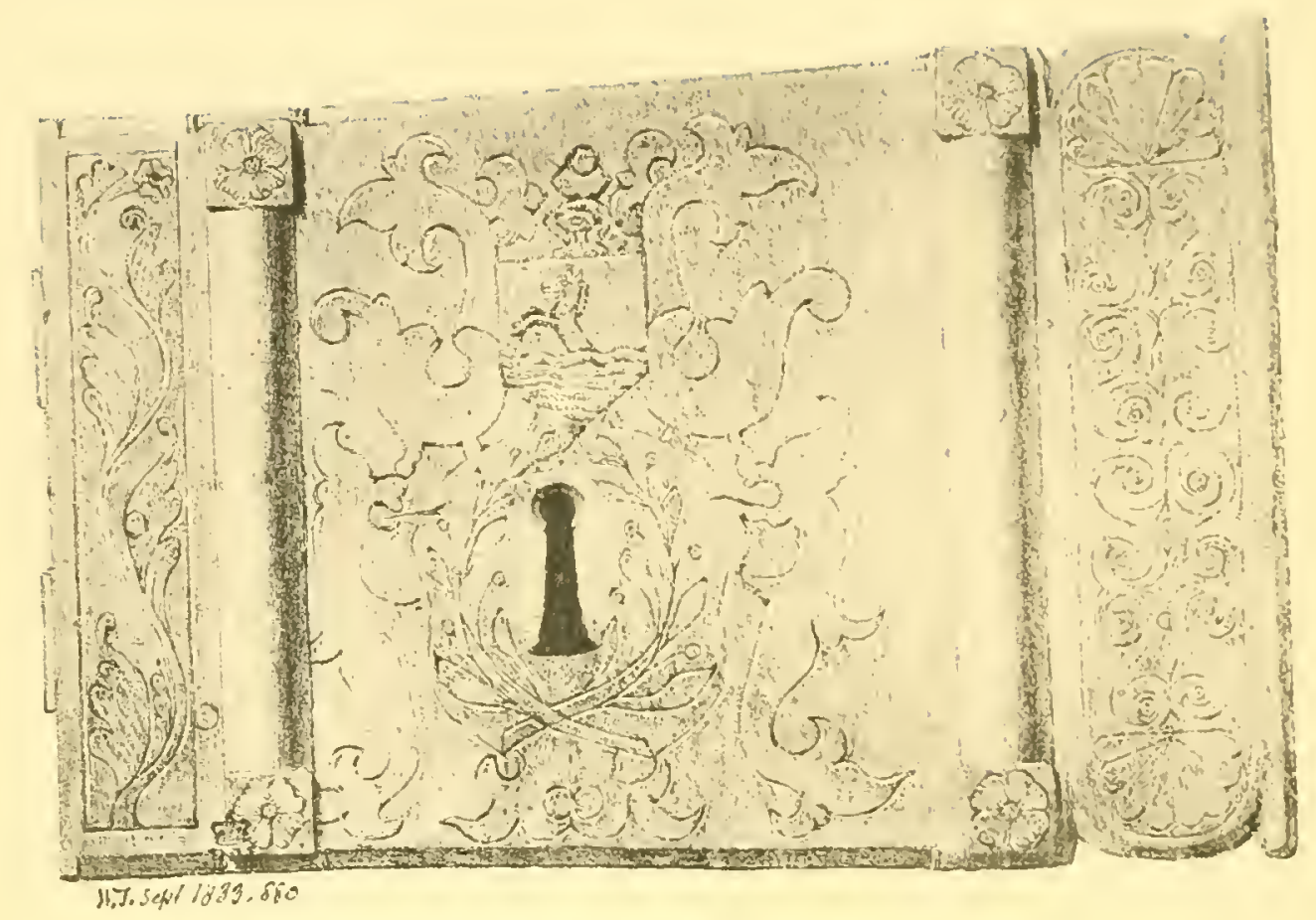

XL. LOCK. NETTLECOMBE COURT. SOMERSET. 


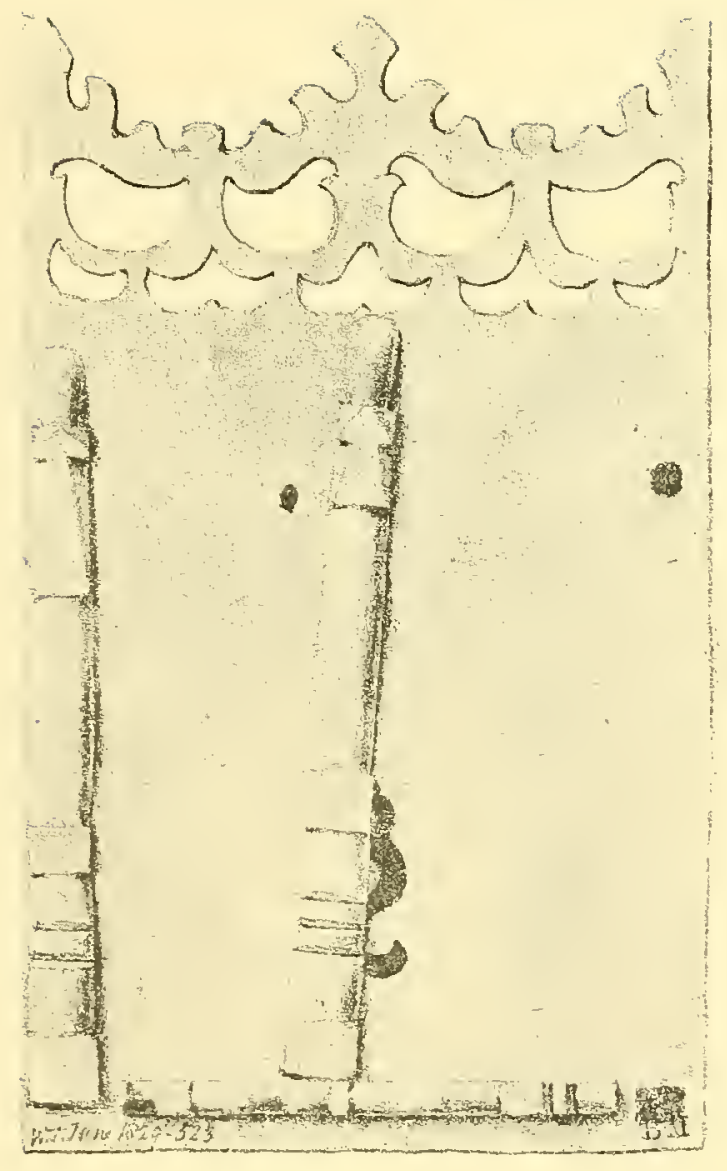

XLI. LOCK, HENGRAVE HALL, SUFFOLK. 


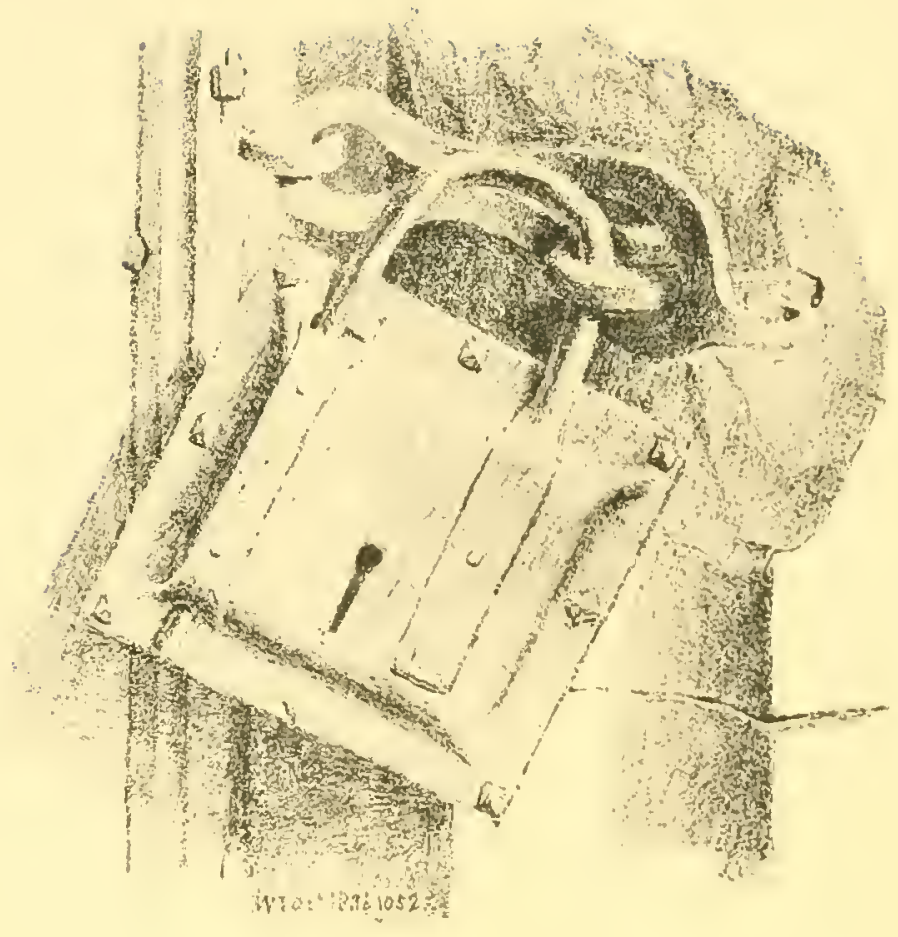

XLII. PADLOCK, THIRSK CHURCH, YORKS. 


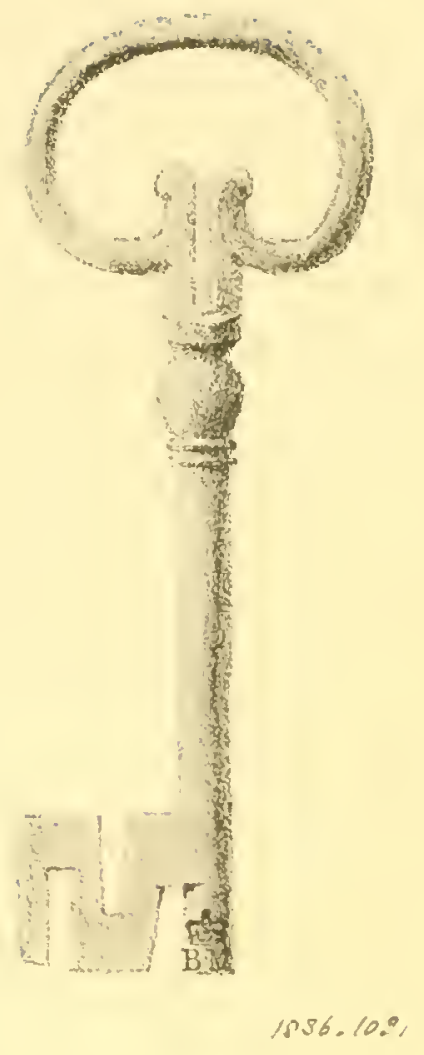

XLIV. KEY IN THE POSSESSION OF ARCHDEACON SINGLETON. 


$$
9
$$




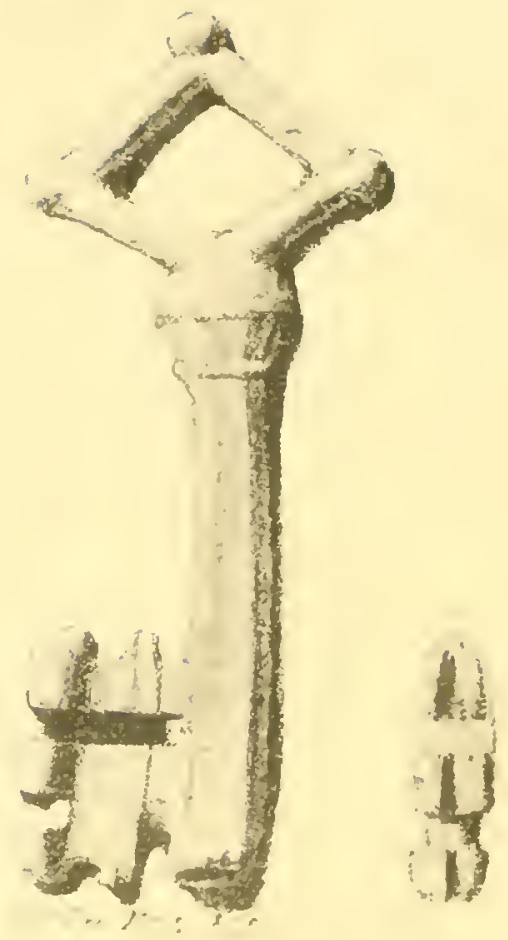

XLVI, COPPER KEY, FOUND AT CAMER, MEOPHAM, KENT. 


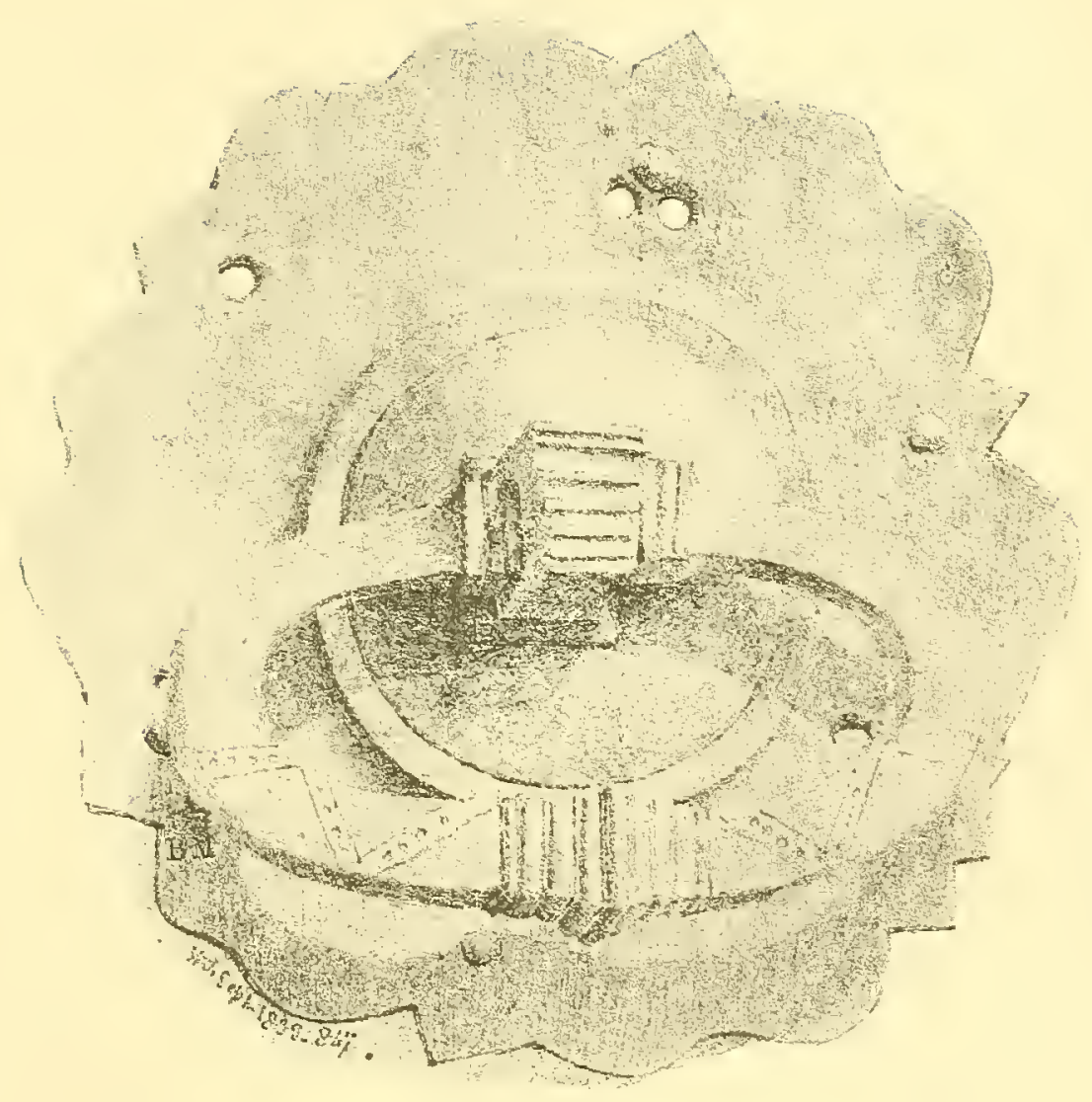

XLVII. DOORHANDLE, WOODLAND, MERE, WILTS. 


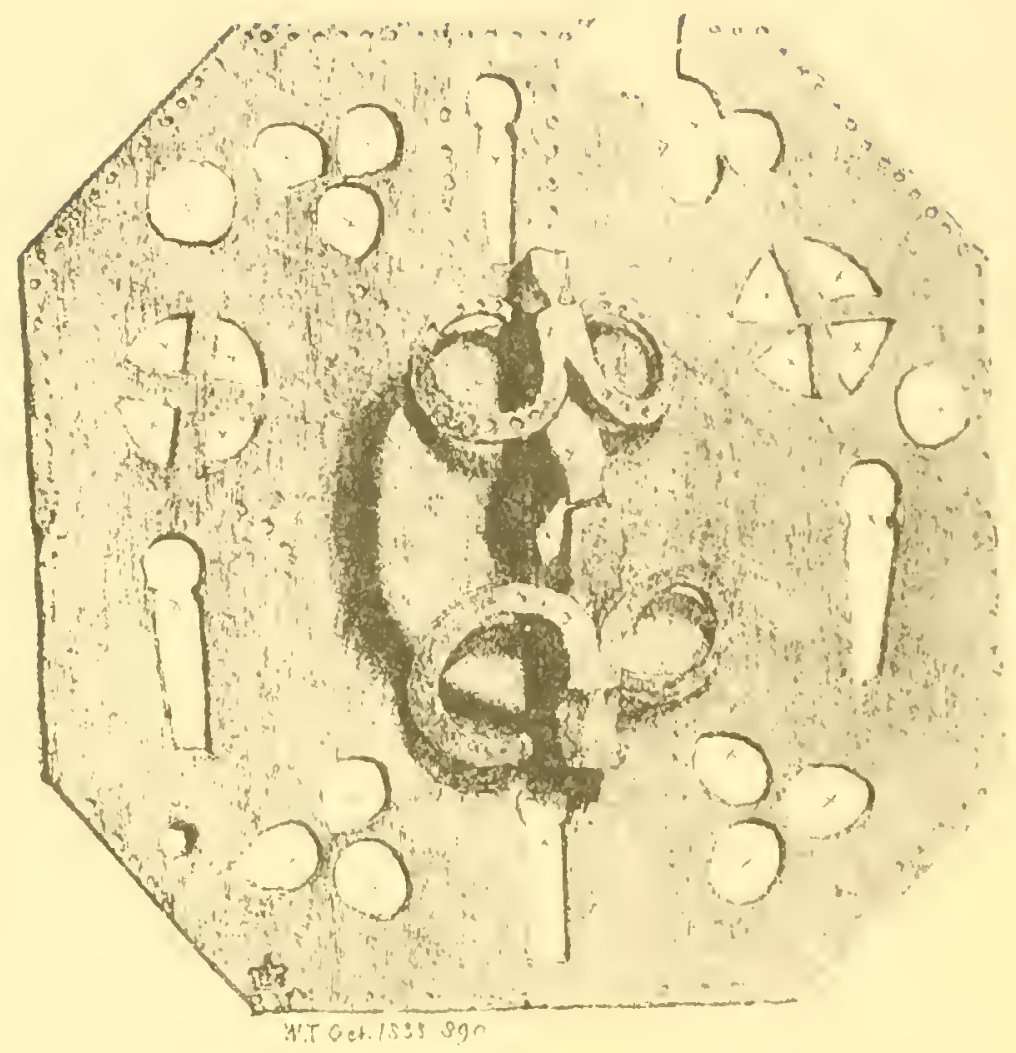

XLYIII, ROSE FOR DOORHANDLE, BREMHILL CHURCH. WILTS. 


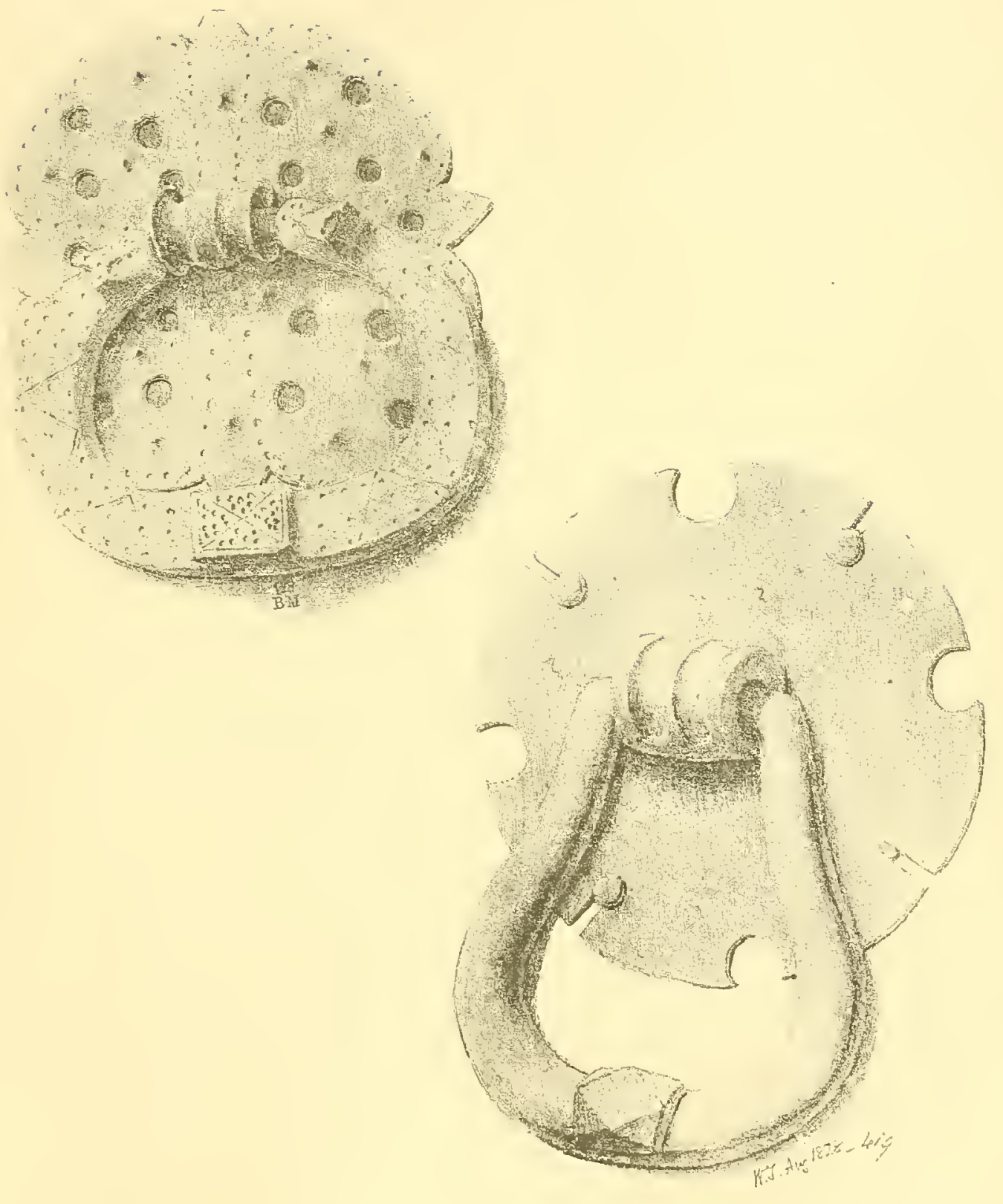

XLIX. DOORHANDLES, SNODLAND CHURCH, KENT. 


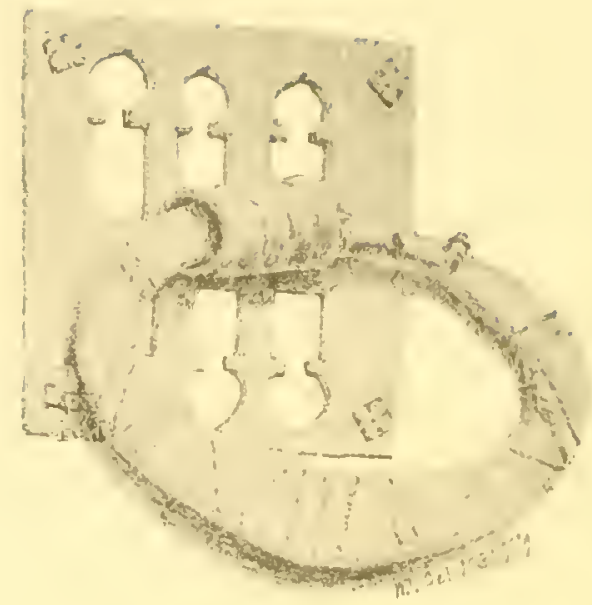

L. DOORHANOLE, BROMHAM CHURCH. WILTS. 


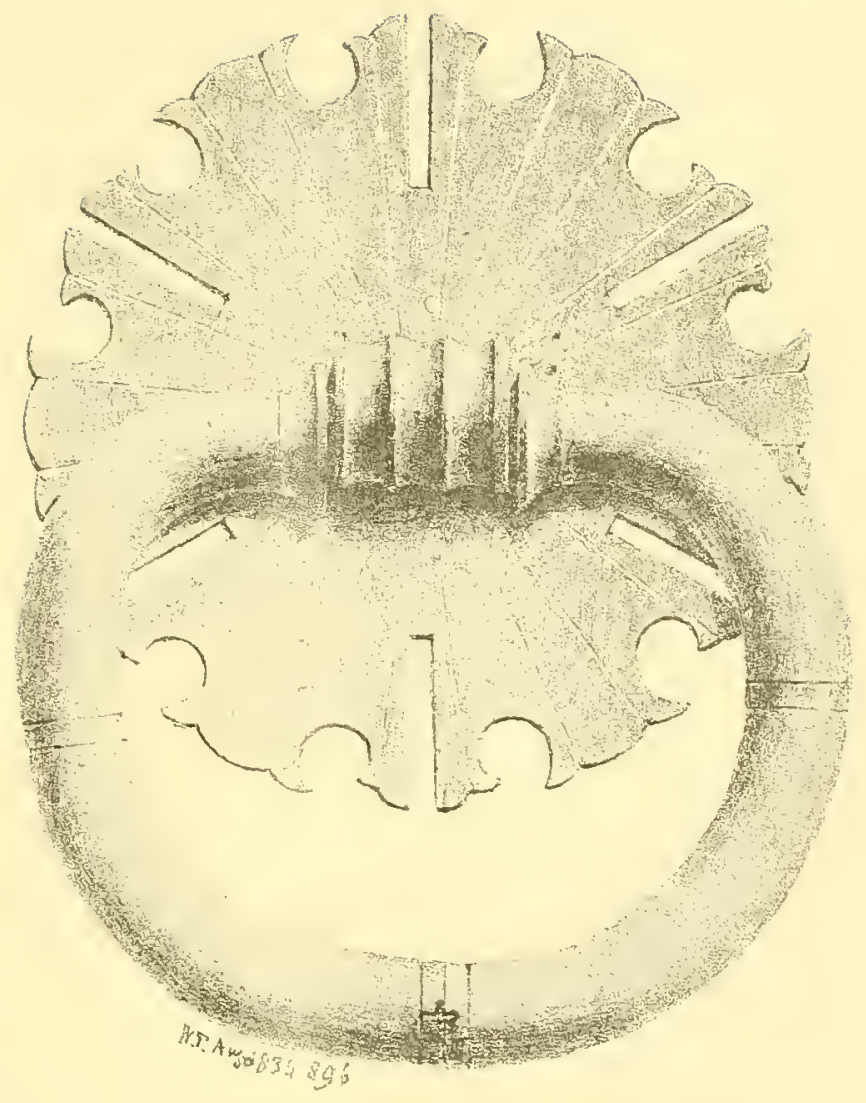

LI. DOORHANDLE, WICKHAM COURT, KENT. 


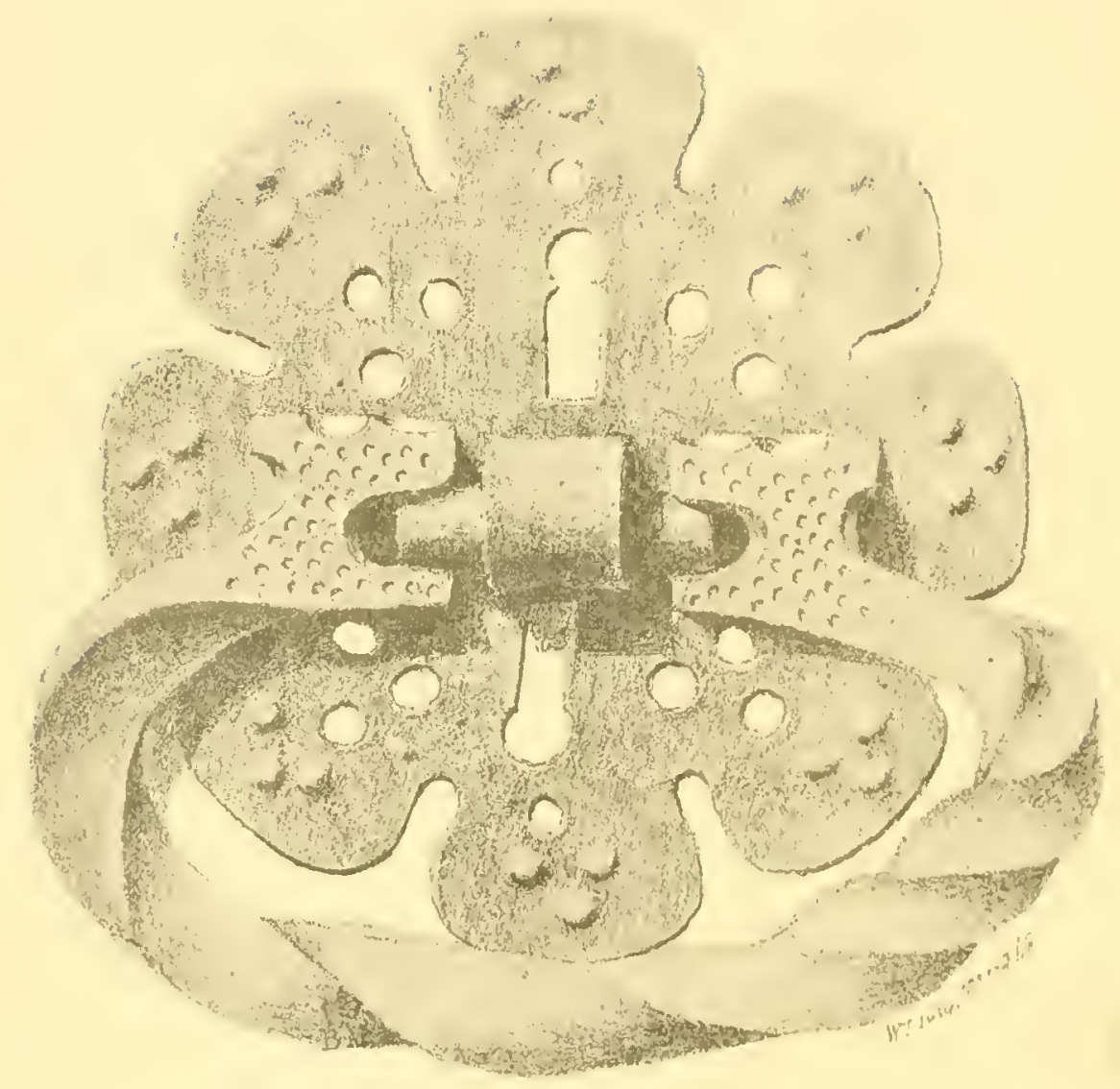

L11. DOORHANDLE. RYARSH CHURCH, KENT. 


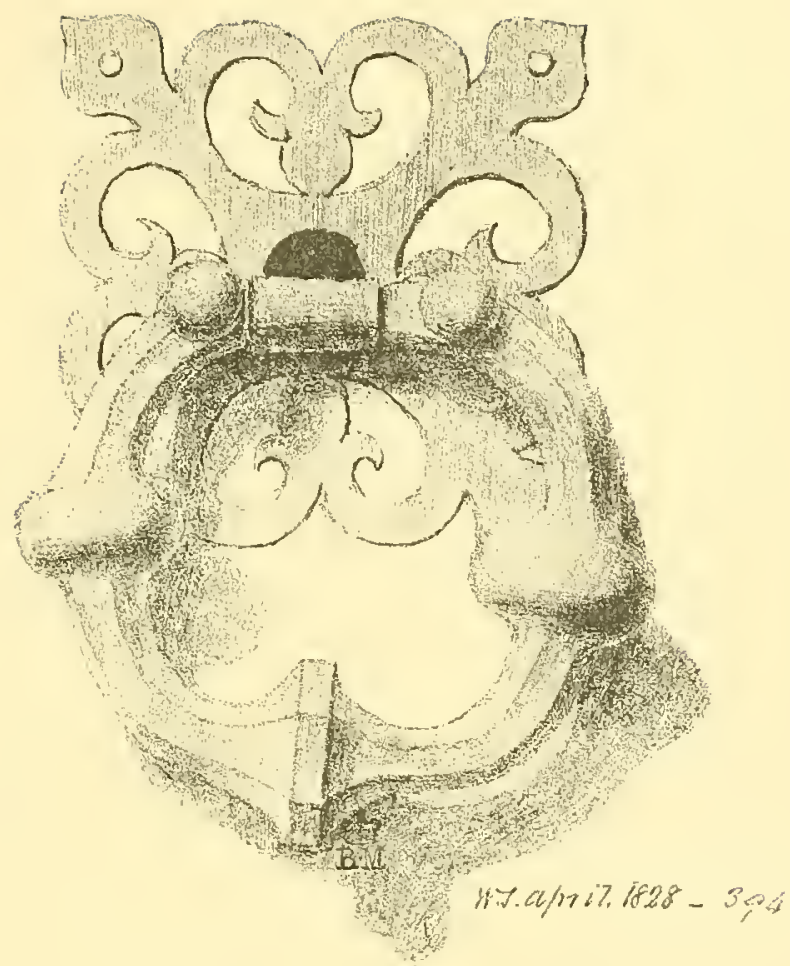

LIII. DOORHANDLE, IGHTHAM MOTE, KENT. 




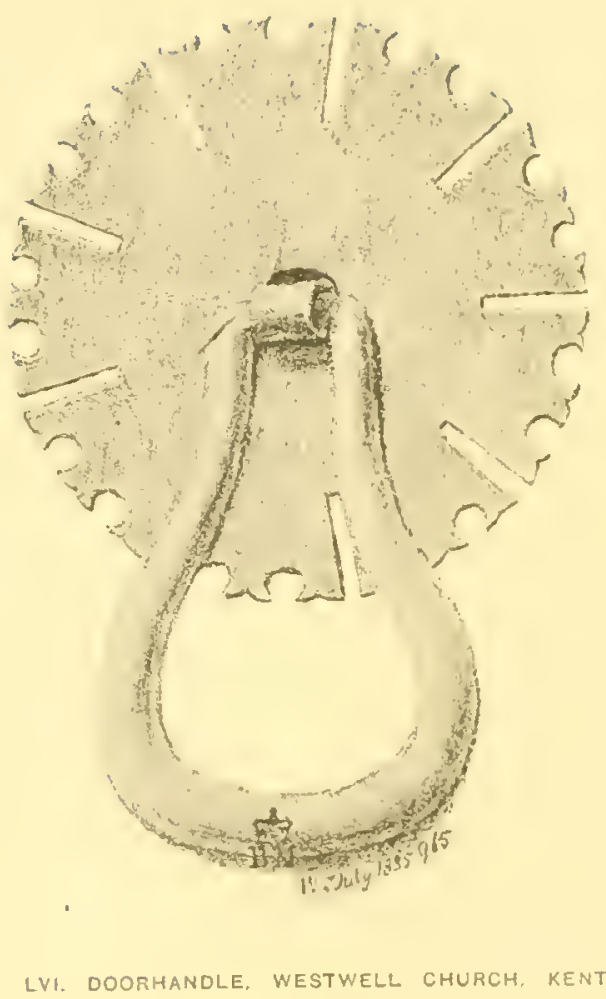





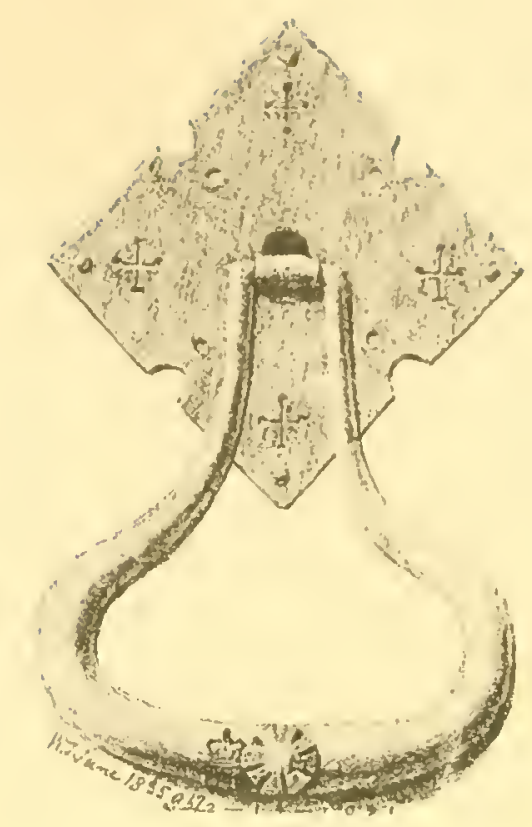

LIX. DOORHANDLE, BROWN'S HOSPITAL, STAMFORD.

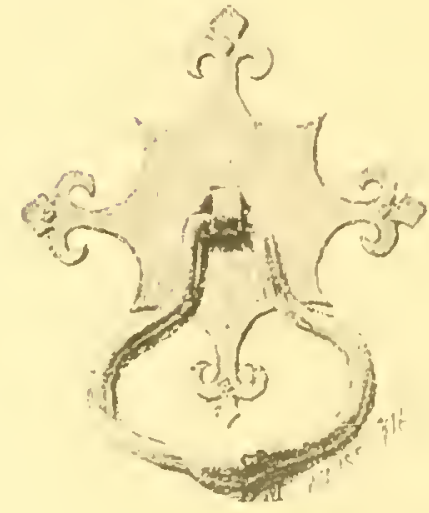

LX. DODRHANDLE, CLAVERTON SOMERSET 


$$
\begin{aligned}
& 98 \\
& \text { t5 }
\end{aligned}
$$



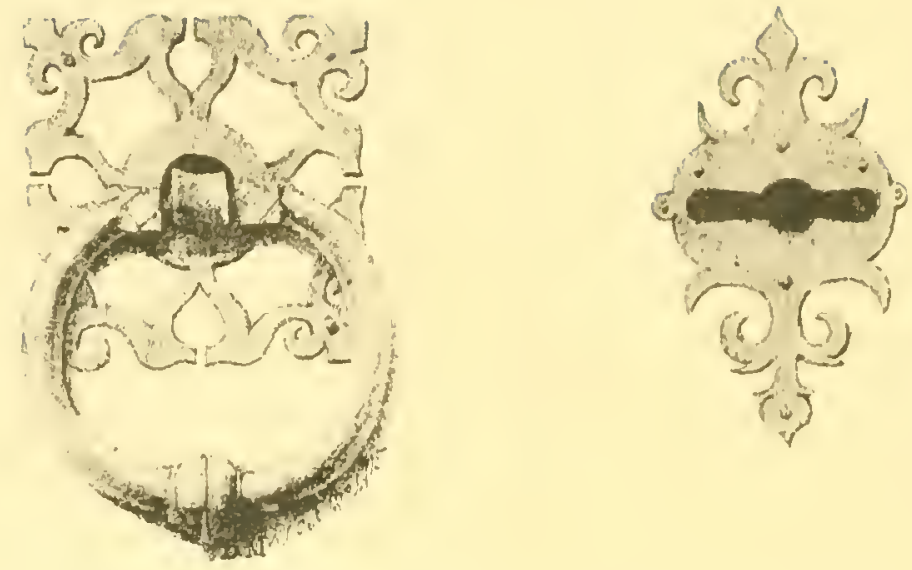

LXIII. DOORHANOLE ANO KEY-ESCUTCHEON, CLAVERTON, SOMERSET. 


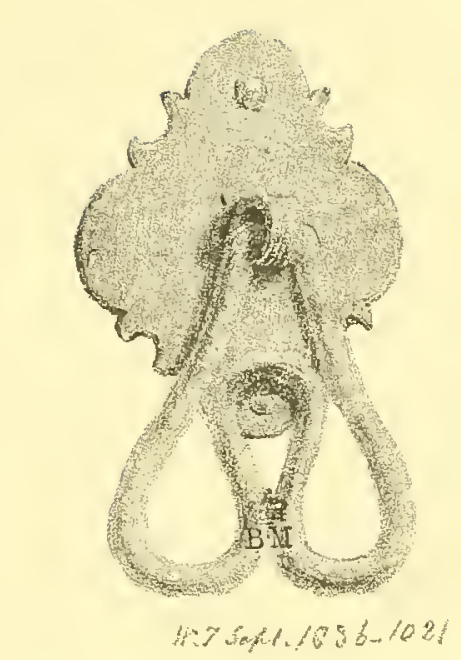

LXIV. DOORHANDLE, KIRKBridge, STANWICK, Yorkshire. 


$$
\text { 骑 } 11
$$



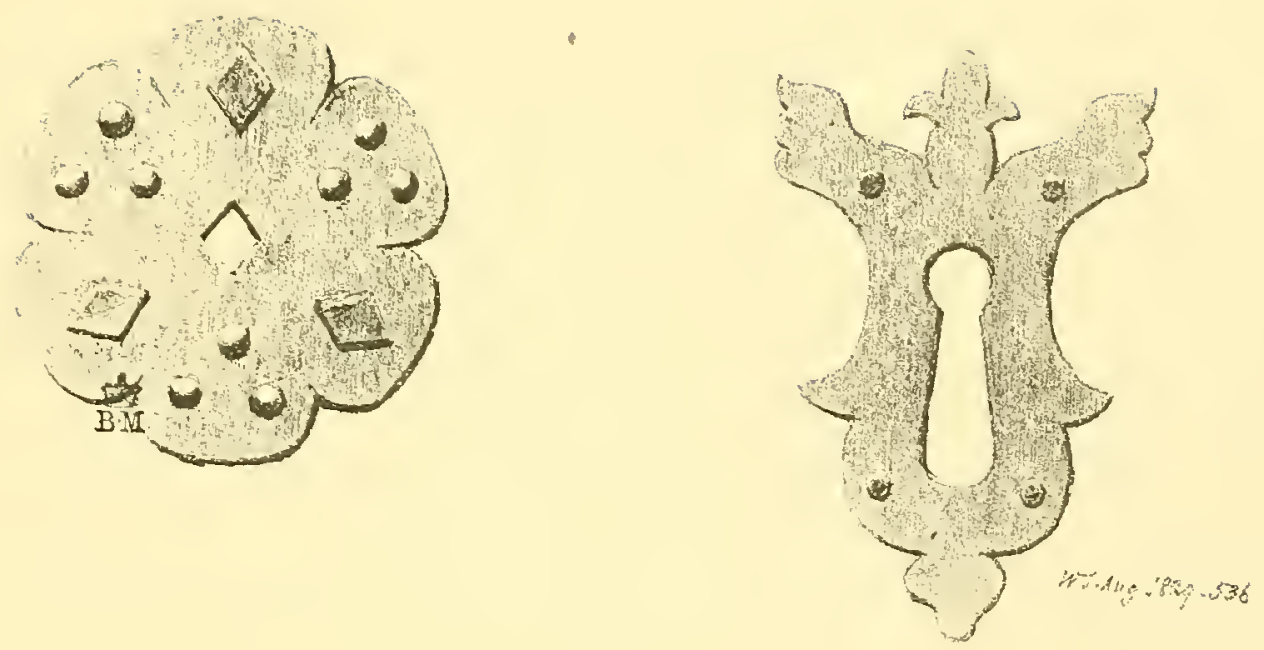

LXVI. HANOLE-ROSE, ST, SEPULCHRE'S, NORTHAMPTON; KEY ESCUTCHEON, THURNHAM CHURCH, KENT, 


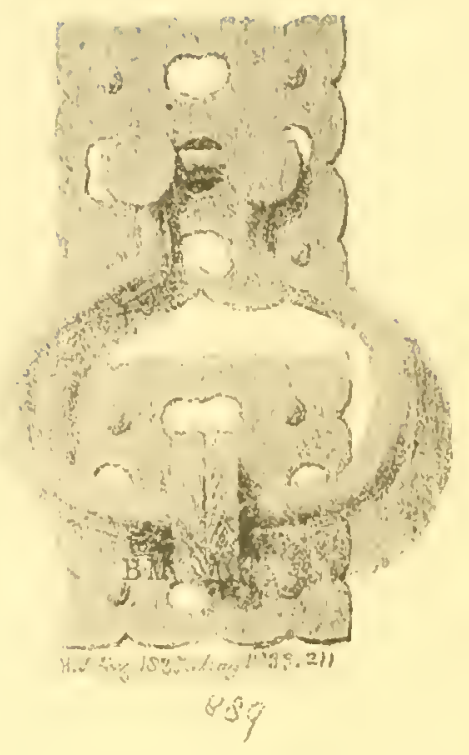

LXVII KNOCKER, BEXON, BREDGAR, KENT 


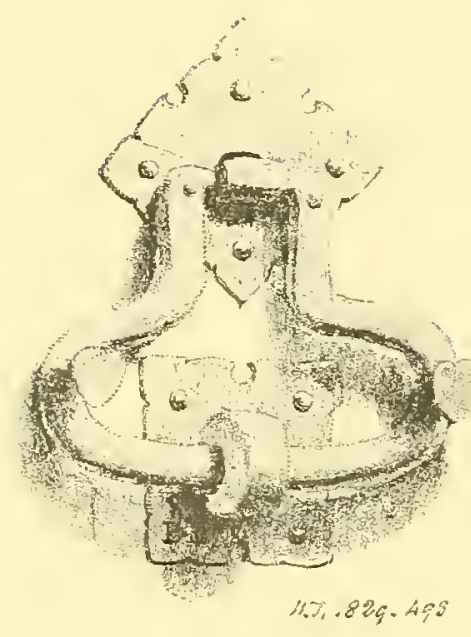

LXVIII, KNOCKER, STROOD, KENT 


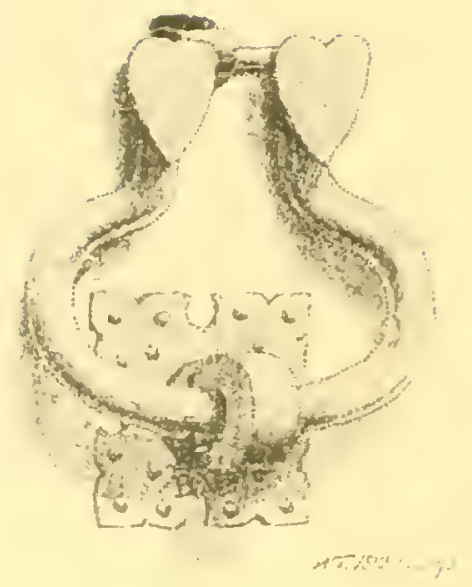

LXIX KNOCKER. ROCHESTER 


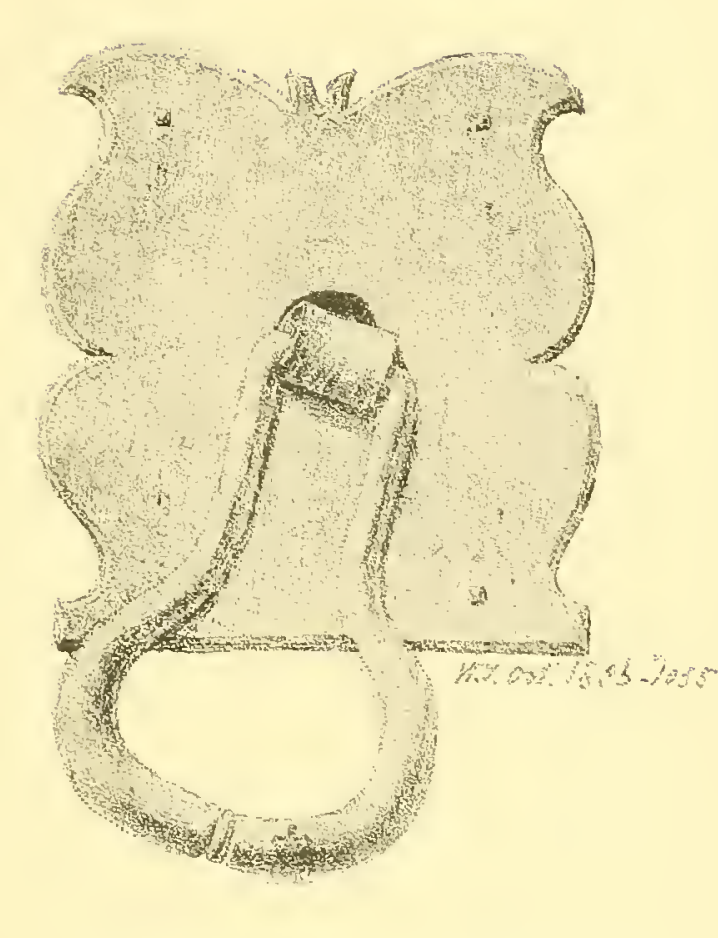




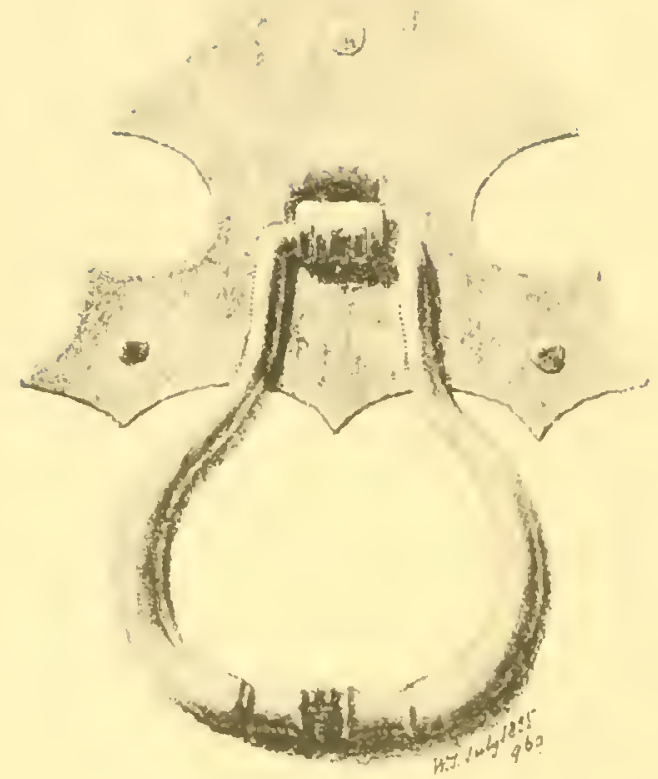

LXXI DOORHANDLE. EGERTON CHURCH, KENT 


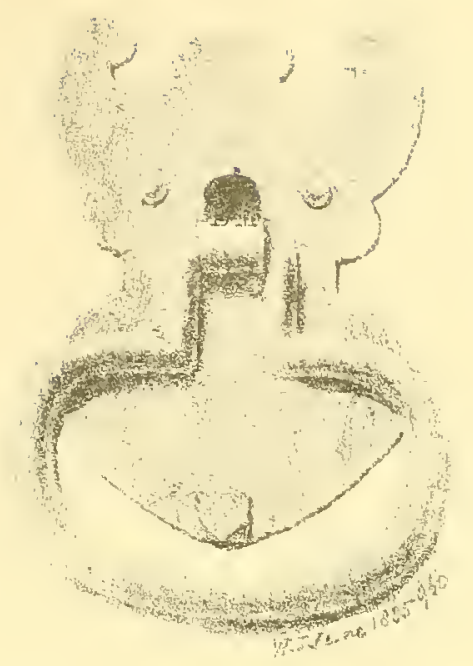

LXXII. DOORHANDLE, CORSHAM, WILTS

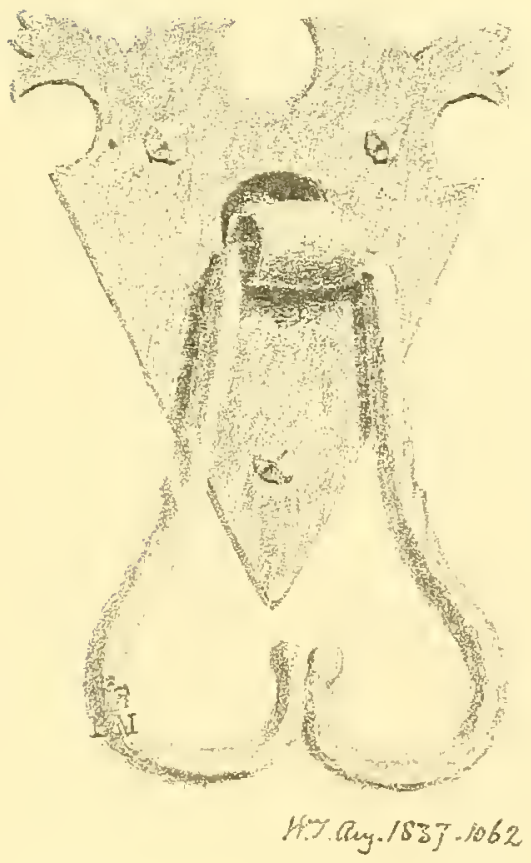

LXXIII. DOOFHANDLE, COULSTEAD, STOCKBURY, KENT 


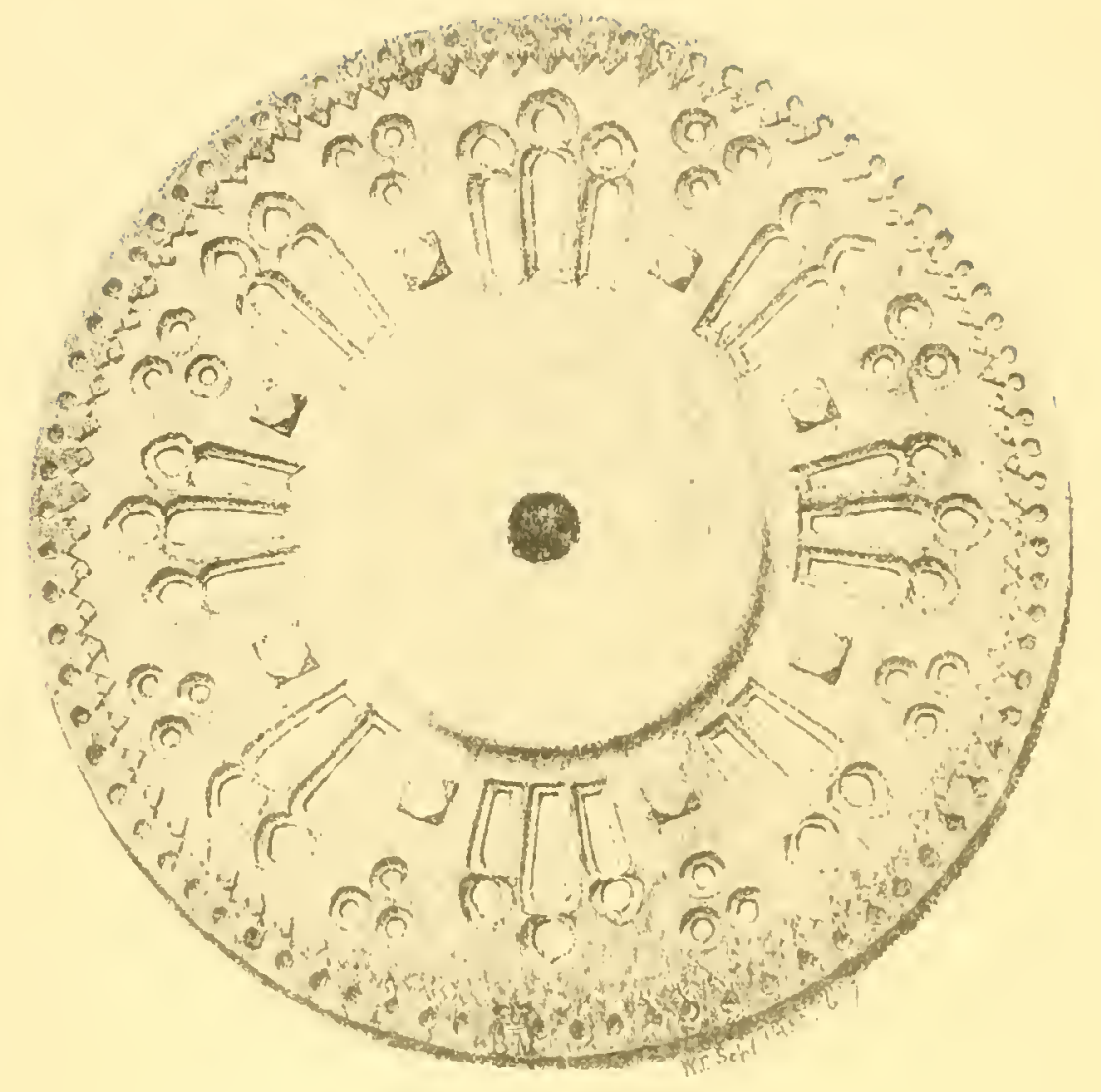




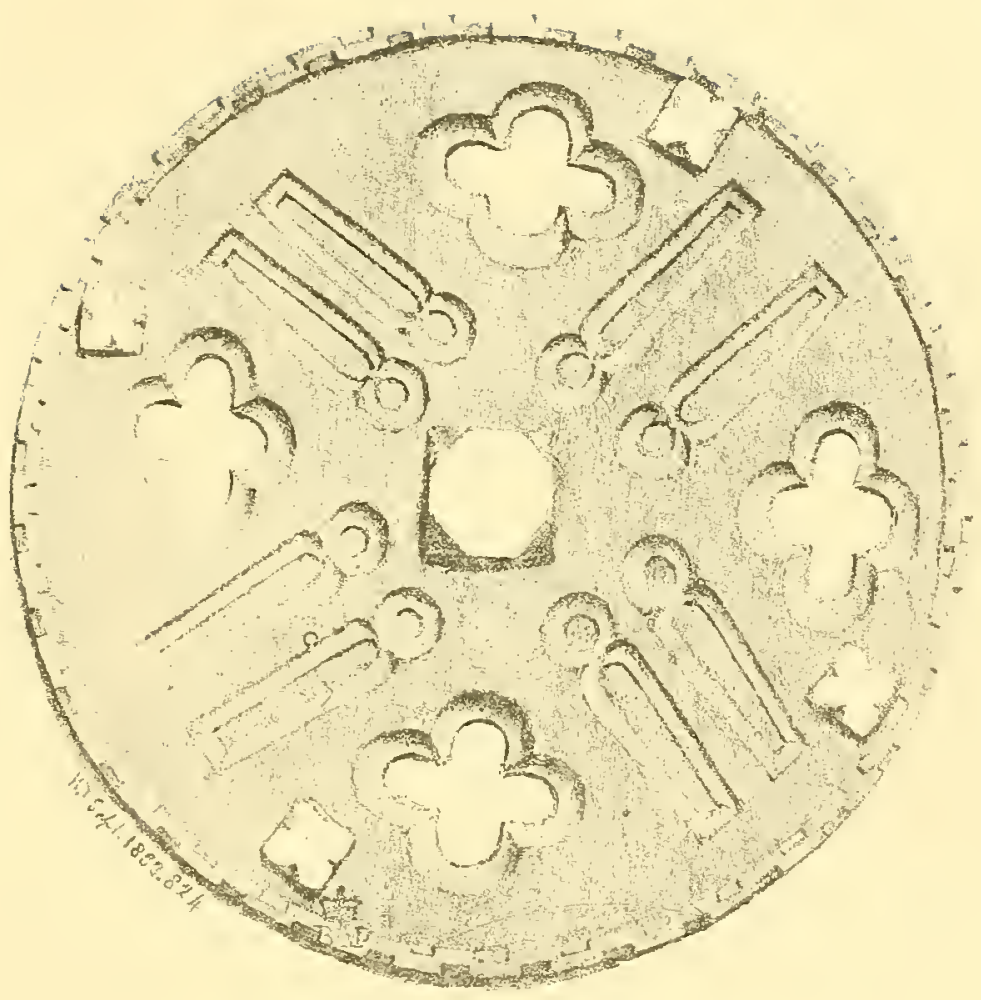

LXXV HANDLE-ROSE, BROWN STREET, SALISBURY 


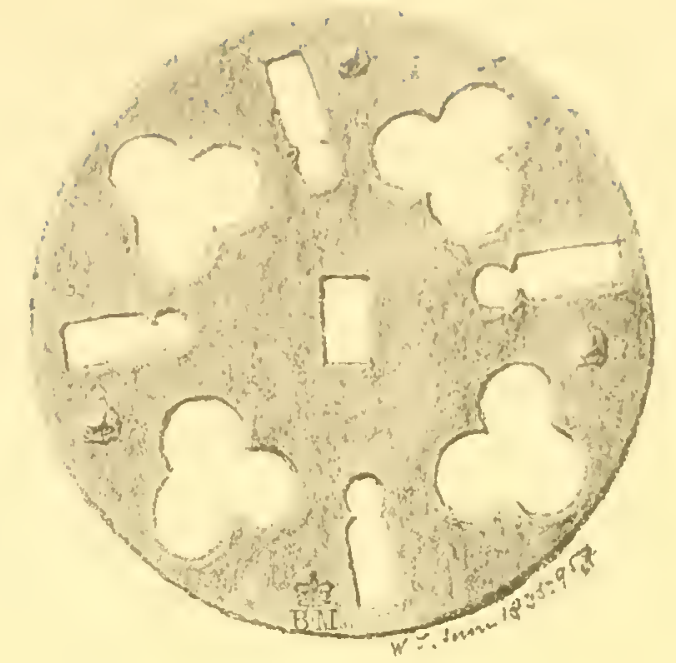

LXXVI HANDLE-ROSE, GILDEN MORDEN CHURCH. CAMBRIDGESHIFE

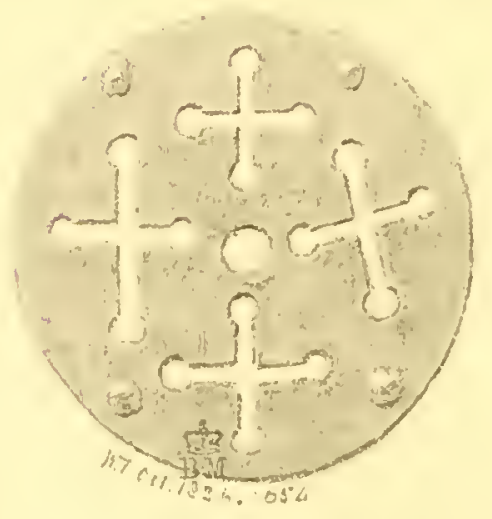

LXXVII. HANDLE-ROSE, CARLEY CHURCH, LINCOLNSHIRE 


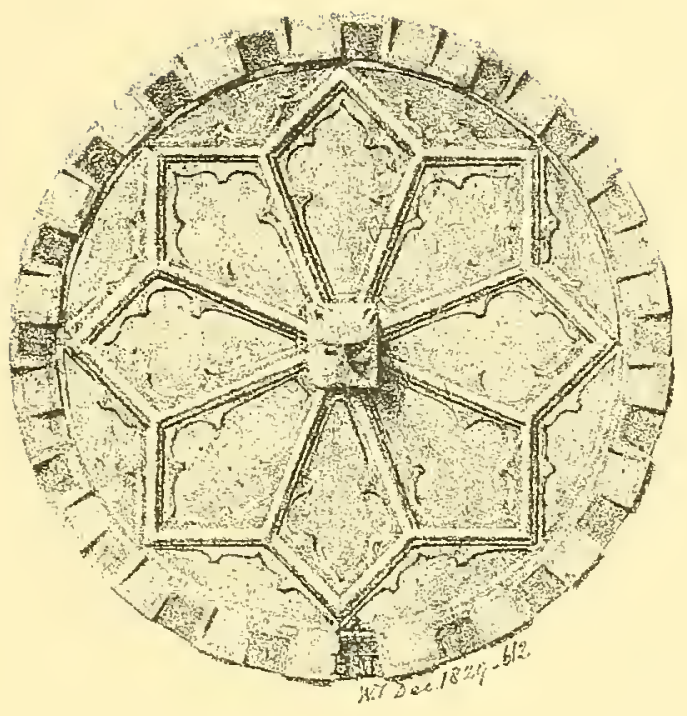

LXXVIII, HANDLE-ROSE, BEAUCHAMP CHAPEL, WARWICK, 


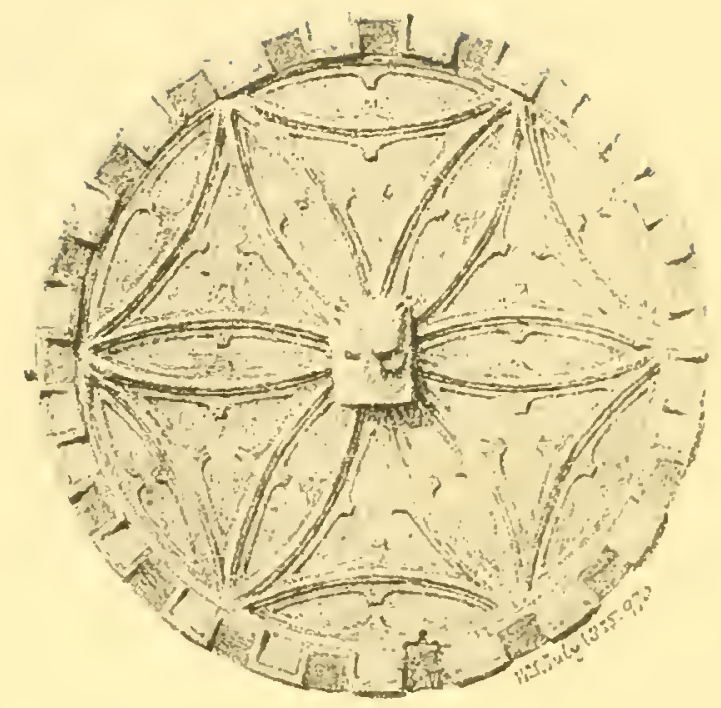

LXXIX, HANDLE-ROSE, BEAUCHAMP CHAPEL, WARWICK. 


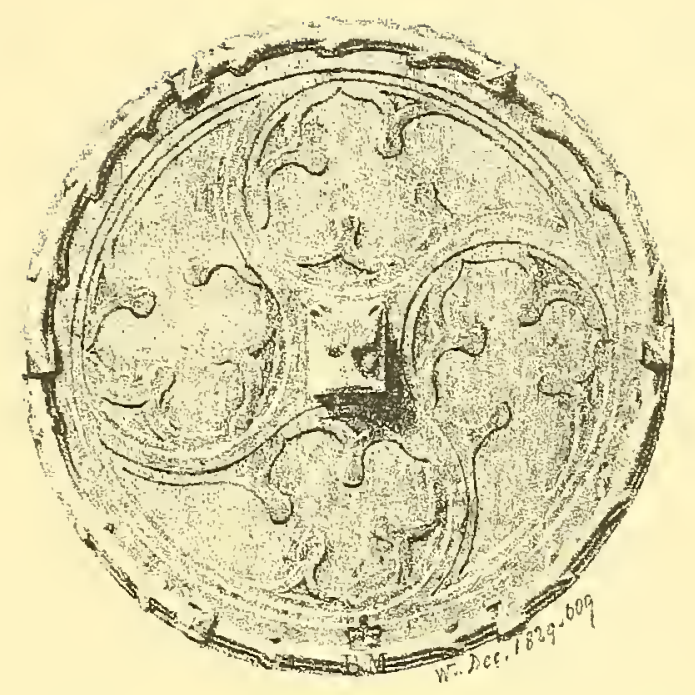

LXXX. HANDLE-ROSE, BEAUCHAMP CHAPEL, WARWICK. 


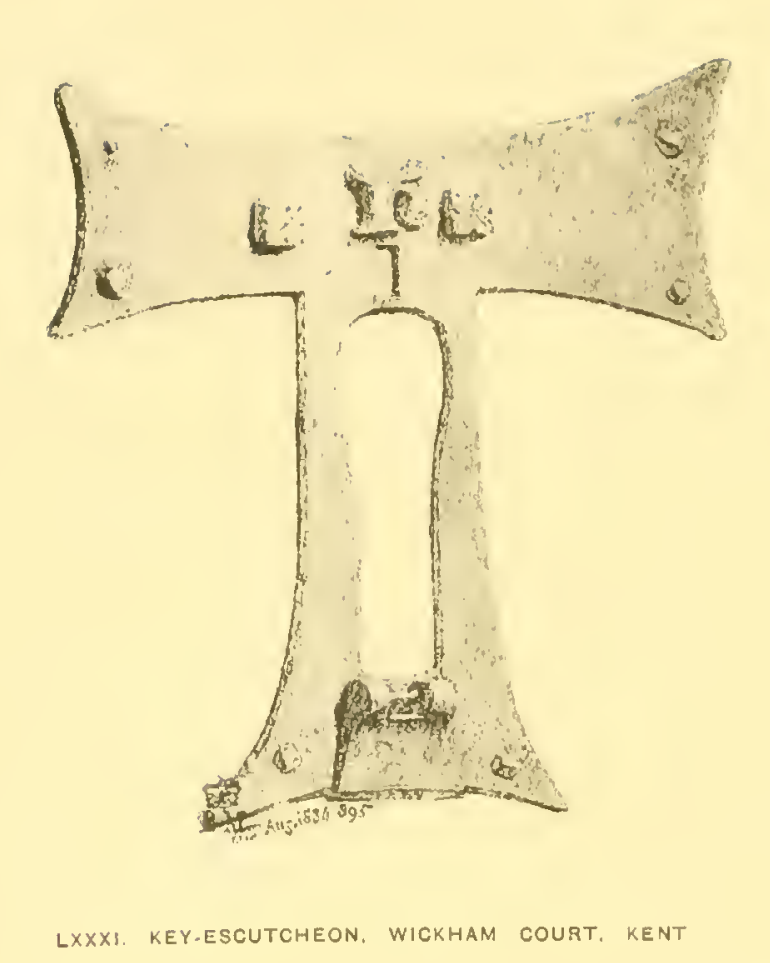




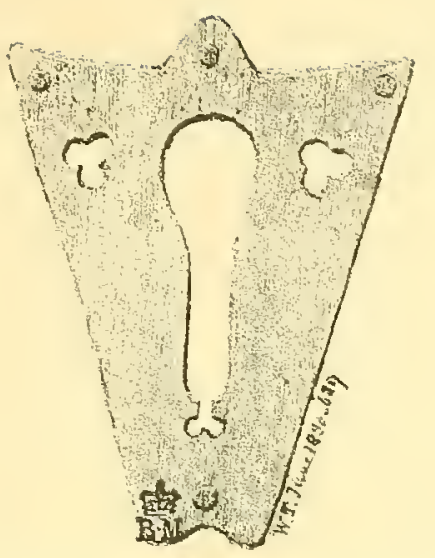

LXXX!I, KEY-ESCUTCHEON, WESTBOURNE GHURCH, SUSSEX.

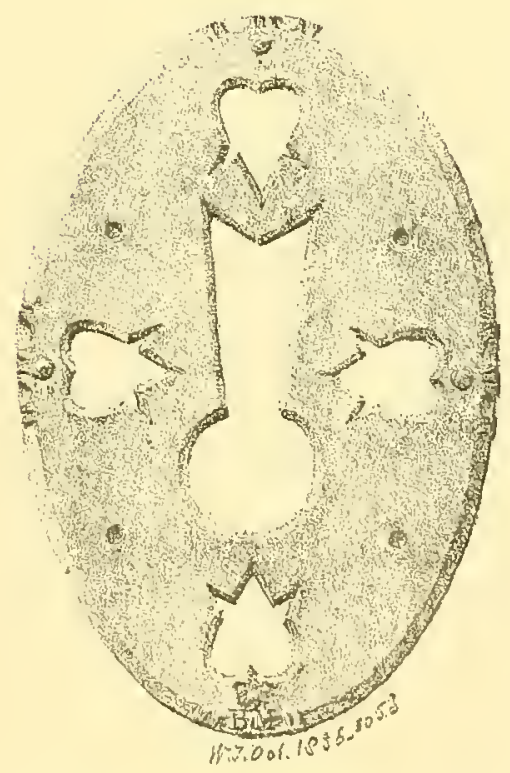

LXXXIII KEY-ESCUTCHEON, HARLAXTON MANOR HOUSE, LINCOLNSHIRE. 


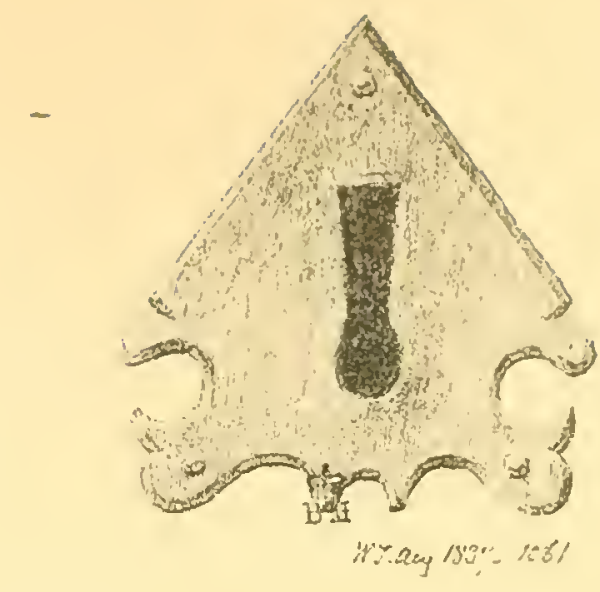

LXXXIV KEY-ESCUTCHEON, COULSTEAD, STOCKBURY, KENT

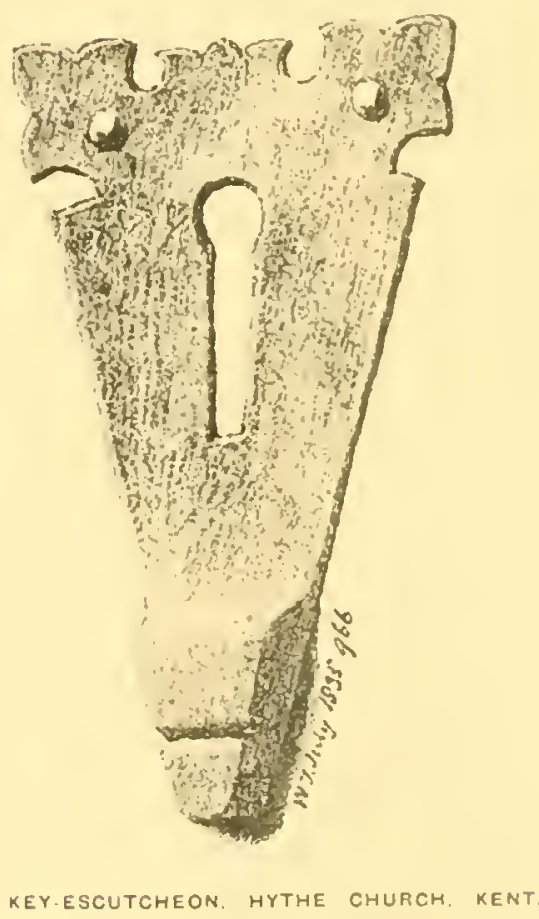




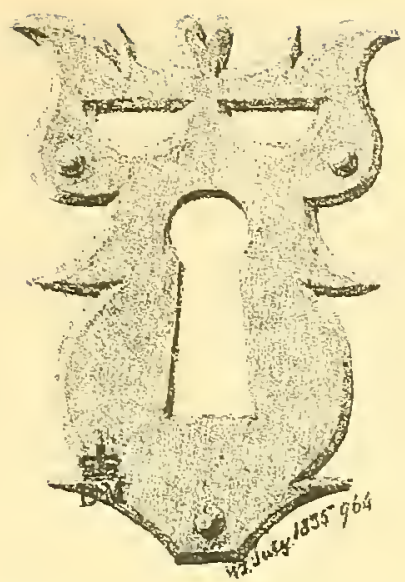

LXXXYI. KEY-ESCUTCHEON, BOUGHTON MALHERGE, KENT.

$\pm$

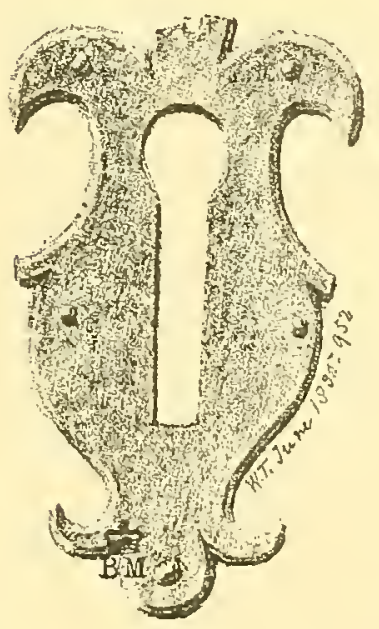

LXXXVII. KEY-ESCUTCHEON, UFFINGTON CHURCH, LINCOLNSHIFE, 


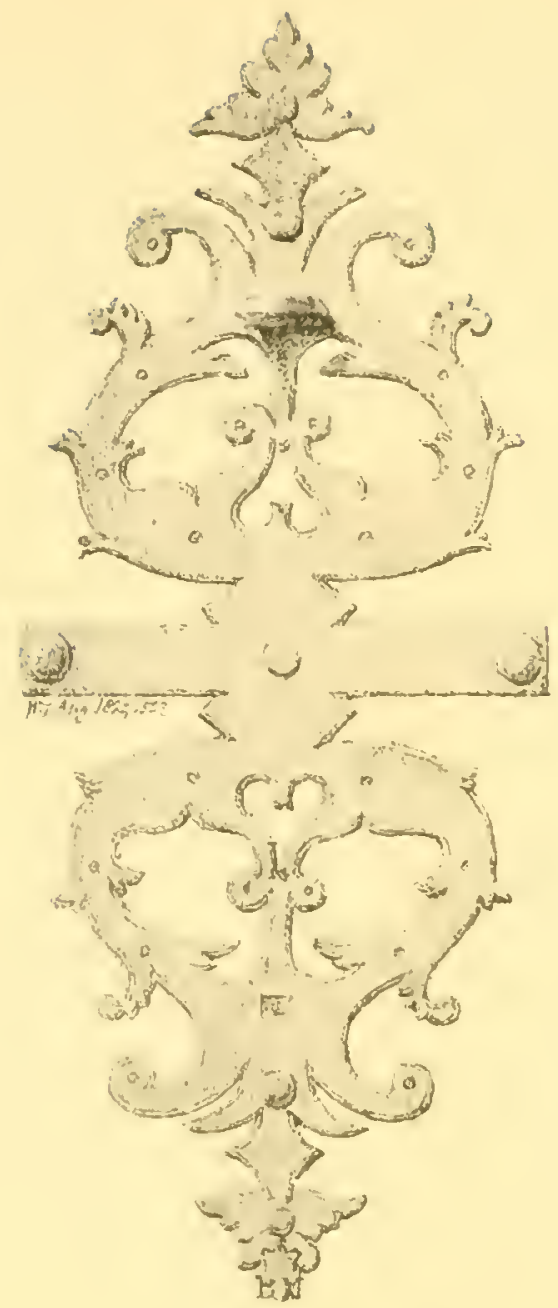

LXXXYII1. HANDLE.PLATE, EASTBURY HOUSE ESSEX 


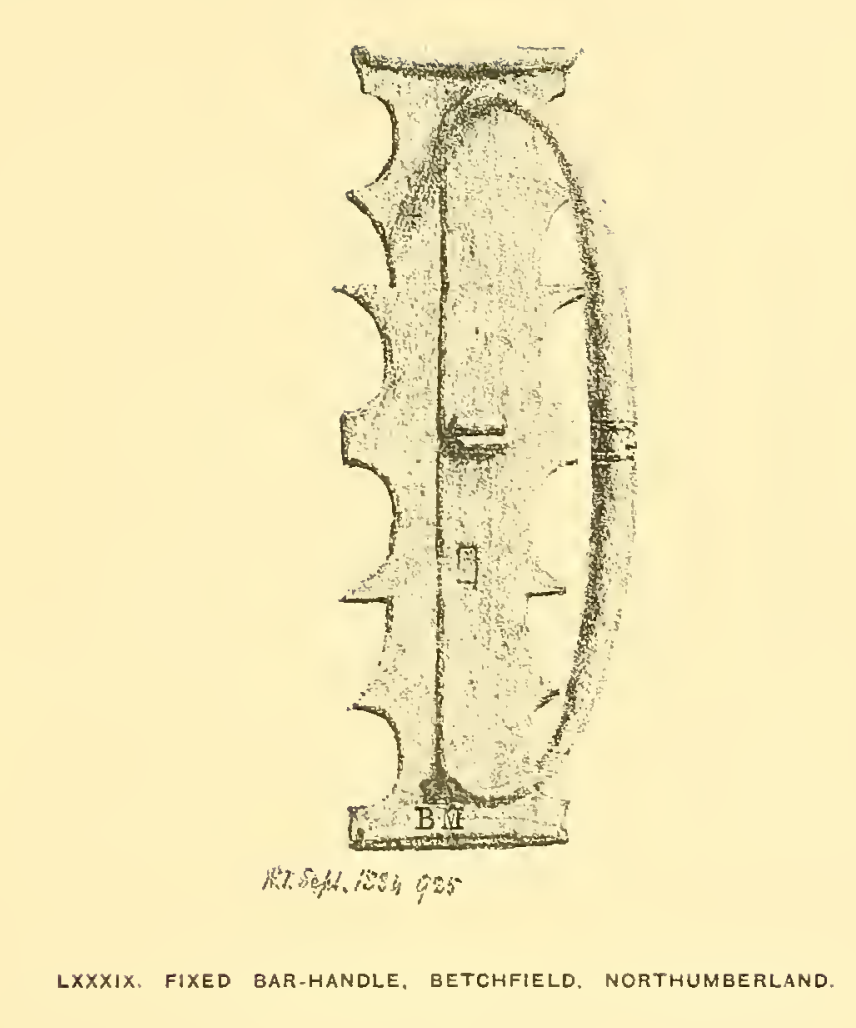




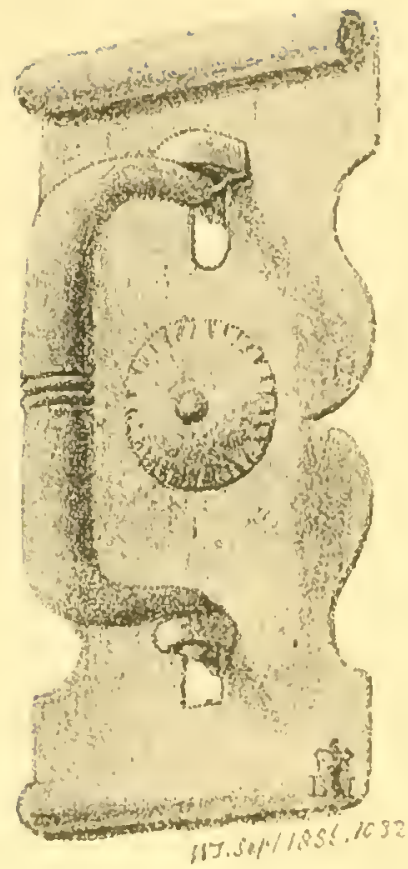

XC. LOOSE BAR-HANDLE, WITTON TOWER, NORTHUMBERLANO 


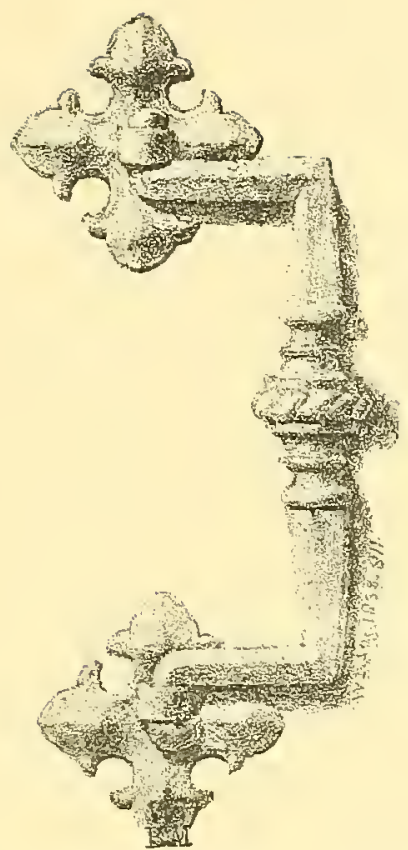

XCl. SWINGING BAR-HANDLE, HAMPTON COURT. 


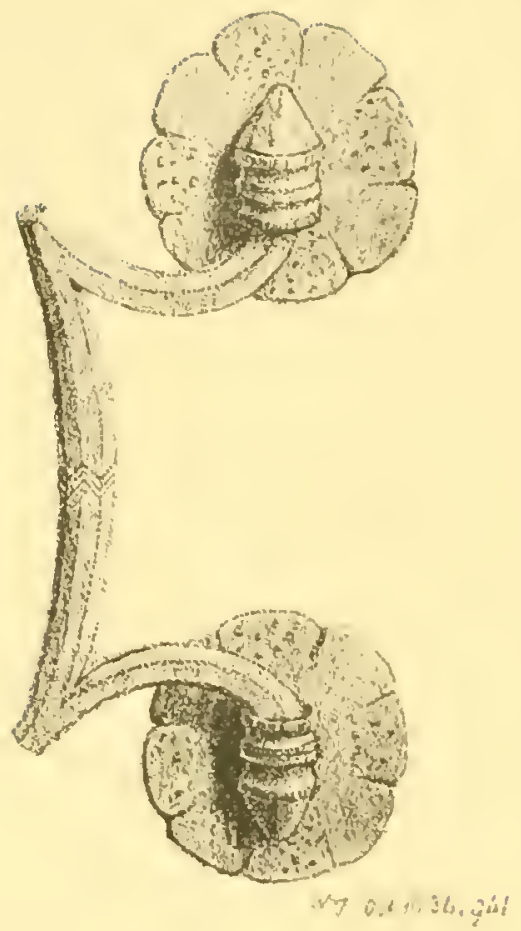

XCII. SWINGING BAR.HANDLE, SEDQEZROOK CHURCH. LINCOLNSHIRE 


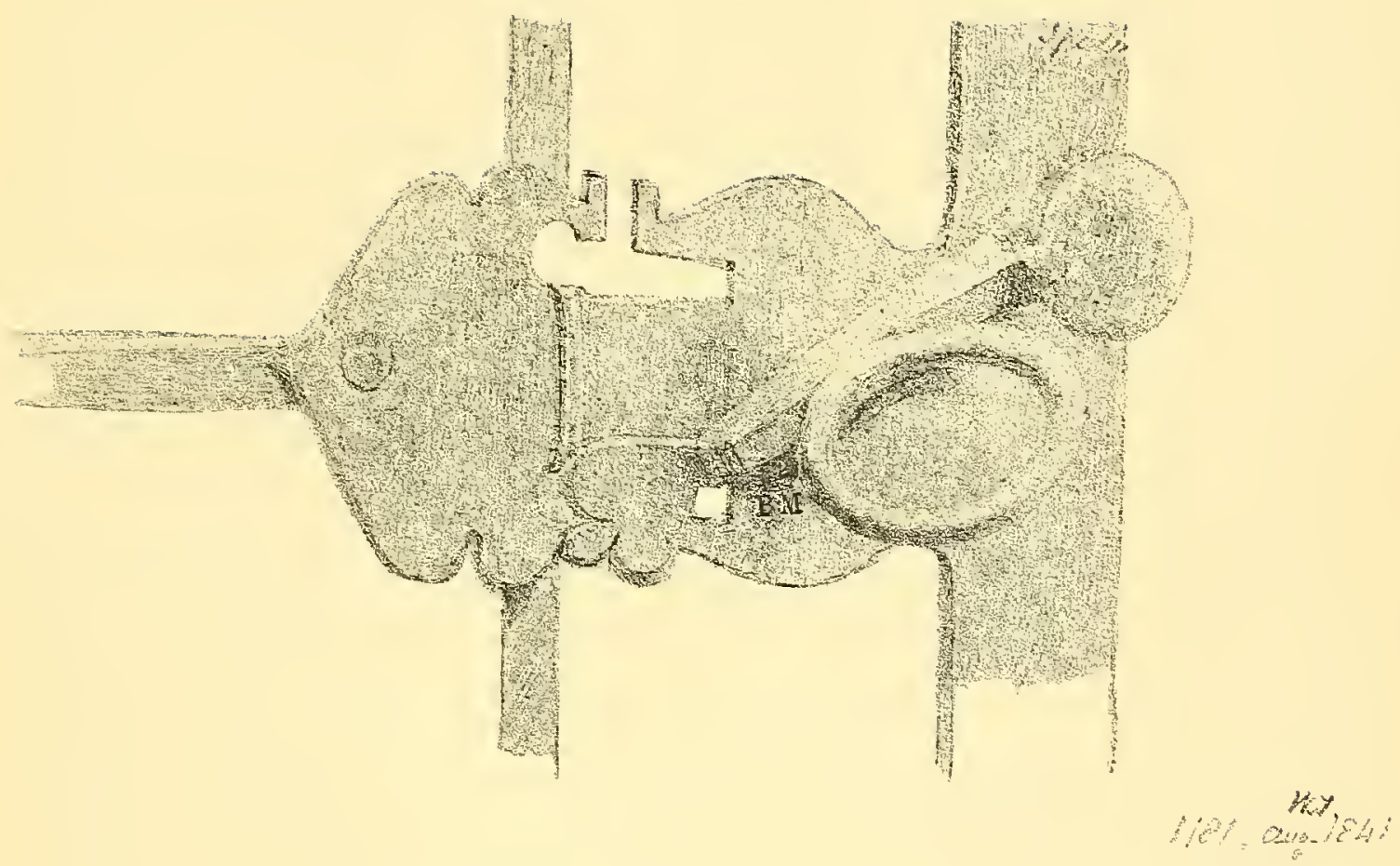

XCIII, WINDOW-LATCH, IPSDEN VICARAGE, OXON 

, 



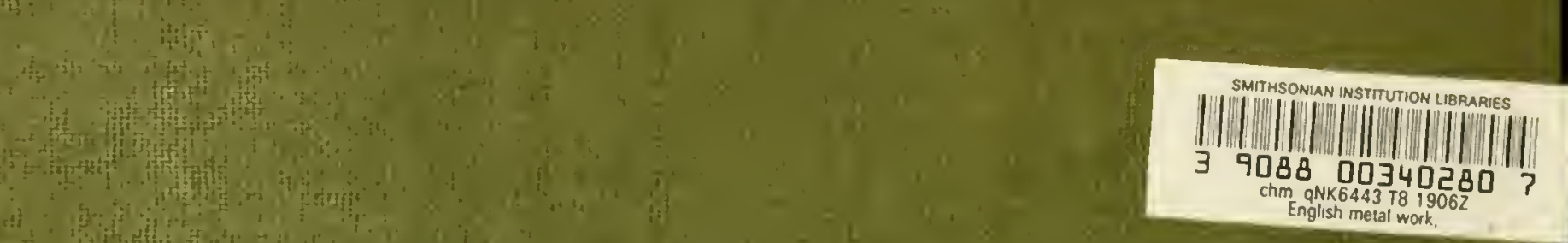

